LUIZ ROGÉRIO MONTEIRO DE OLIVEIRA

\title{
OS LAUDOS PERICIAIS NAS AÇÕES JUDICIAIS POR ERRO MÉDICO: UMA ANÁLISE CRÍTICA
}

DissertaÇÃo DE MESTRAdo

Orientador: Prof. Dr. Roberto Augusto de CARVAlho CAmpos

FACULDADE DE DIREITO DA USP

SÃO PAULO

2010 


\title{
OS LAUDOS PERICIAIS NAS AÇÕES JUDICIAIS POR ERRO MÉDICO: UMA ANÁLISE CRÍTICA
}

\begin{abstract}
Dissertação de Mestrado apresentada à Banca Examinadora da Faculdade de Direito da Universidade de São Paulo, como exigência parcial para a obtenção do título de Mestre em Direito, sob orientação do Prof. Dr. Roberto Augusto de Carvalho Campos.
\end{abstract}

FACULDADE DE DIREITO DA USP

SÃO PAULO

2010 
Oliveira, Luiz Rogério Monteiro de

Os laudos periciais nas ações judiciais por erro médico : uma análise crítica / Luiz Rogério Monteiro de Oliveira. - São Paulo : L.

R. M. de Oliveira, 2010.

$94 \mathrm{f}$; $30 \mathrm{~cm}$.

Dissertação (Mestrado) - Faculdade de Direito da USP, 2010.

Orientador: Prof. Doutor Roberto Augusto de Carvalho Campos.

Contém apêndice

Notas de rodapé

Inclui bibliografia

1. Laudo pericial. 2. Perito. 3. Prova. 4. Responsabilidade civil. 5. Medicina Forense. I. Título.

CDU 347.948 (043)

Vedada a reprodução e divulgação total ou parcial deste trabalho, por qualquer meio convencional ou eletrônico, salvo com autorização expressa do autor. 
Banca Examinadora 


\section{DEDICATÓRIA}

Dedico este trabalho aos meus pais, Adahyr e Luiz, aos meus irmãos Fátima, Luiz Fernando e Luiz Eduardo e à minha companheira Paula, com amor, admiração e gratidão pela compreensão, carinho, presença e apoio ao longo do período de elaboração deste escrito. 


\section{AGRADECIMENTOS}

Ao Prof. Dr. Roberto Augusto de Carvalho Campos, pela atenção e apoio durante o processo de definição, orientação e escrita.

Ao Des. e Min. Sidnei Agostinho Beneti, que, nos anos de convivência, muito me ensinou, contribuindo para meu crescimento intelectual e jurídico.

Ao Des. Octavio Roberto Cruz Stucchi (in memoriam), por ter me incentivado e acreditado em meu potencial.

À Faculdade de Direito da Universidade de São Paulo, pela oportunidade de realização do curso de mestrado. 
A grande responsabilidade do ser humano consiste em saber discernir. O mundo espera que cada um de nós assuma esta importante tarefa do justo equilíbrio.

Textos Judaicos Fonte: Rabi Yaacov ben Shimon 


\section{RESUMO}

OLIVEIRA, L. R. M. Os laudos periciais nas ações judiciais por erro médico: uma análise crítica. 2010. 94 p. Dissertação (Mestrado) - Faculdade de Direito, Universidade de São Paulo, São Paulo, 2010.

A proposta deste trabalho é fazer uma apreciação crítica dos laudos periciais realizados em ações judiciais de responsabilidade civil por alegado erro médico. A prova pericial deve orientar o julgador para que este possa fixar os limites da responsabilidade do médico ou profissional de saúde. O perito deve responder adequadamente as questões discutidas no processo, bem como trazer ao juiz os elementos que considerar úteis ou necessários para auxiliar a decisão judicial. Na parte teórica são estudados os campos de apuração da responsabilidade por erro médico, os pressupostos da responsabilidade civil, os tipos de prova que podem ser produzidos no processo, quais são os elementos essenciais do laudo pericial e os critérios que devem ser usados pelo perito para determinar se estão presentes os requisitos do dever de indenizar. Em seguida, utilizando-se dados obtidos em processos judiciais, são abordados os aspectos mais relevantes nas ações desta espécie, como a incidência dos tipos de dano alegados pelos autores, as especialidades médicas mais acionadas judicialmente, o tempo médio entre o ajuizamento da ação e a sentença judicial e a relevância dos laudos nas decisões judiciais observadas. Ao final, é realizada uma análise crítica dos conteúdos dos laudos, verificando se eles contêm todos os elementos recomendados e descritos na parte teórica, fazendo-se críticas sobre se eles cumpriram sua função de forma adequada e propondo instrumentos para seu aperfeiçoamento.

Palavras-chave: Laudo pericial. Perito. Prova. Responsabilidade civil. Medicina Forense. 


\begin{abstract}
OLIVEIRA, L. R. M. Expert reports in medical malpractice lawsuits: a critical analysis. 2010. 94 p. Dissertação (Mestrado) - Faculdade de Direito, Universidade de São Paulo, São Paulo, 2010.

The aim of this work is to do a critical appreciation of the expert reports in judicial proceedings for alleged medical malpractice. The expert report should guide the judge and help to determine the limits of the physician's or health professional's responsibility. The expert must answer appropriately the questions discussed in the lawsuit, as well as bringing the elements that he or she might consider useful or necessary to aid the judicial decision. The theoretical section concerns the medical malpractice responsibility verification, the presupposed civil responsibility, the kinds of proof that can be produced in the process, what are the essential elements of the expert report, and which criteria that should be used by the expert to determine if the requirements of the duty of compensating are present. Then, using data obtained from judicial proceedings, the most important aspects in this kind of lawsuit are exposed, such as the incidence of types of damage alleged by the authors, the most prosecuted medical specialties, the average time between the beginning of the action and the judicial sentence, and the relevance of the expert reports in the observed judicial decisions. At the end, a critical analysis of the reports is accomplished, verifying if they contain all the recommended elements described in the theoretical part, criticizing the accomplishment of their function, and proposing instruments for their improvement.
\end{abstract}

Keywords: Expert report. Expert. Proof. Civil responsibility. Forensic Medicine. 


\section{SUMÁRIO}

1 INTRODUÇÃO......................................................................................................... 10

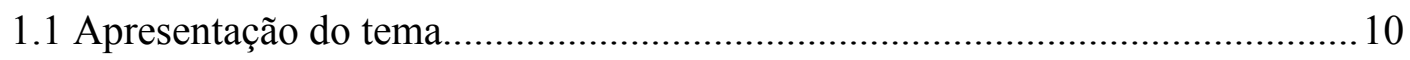

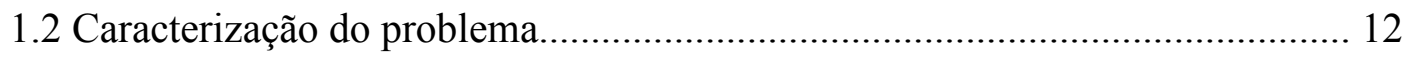

1.3 Objetivos e aspectos a serem abordados.................................................... 13

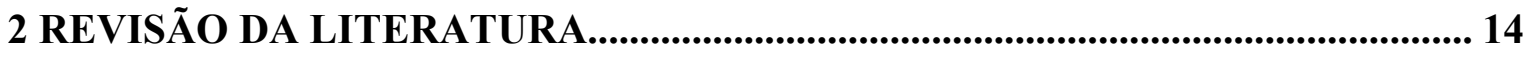

$2.1 \mathrm{O}$ erro médico no mundo e no Brasil................................................................. 14

2.2 Campos de apuração da responsabilidade por erro médico............................... 15

2.3 Responsabilidade objetiva e subjetiva......................................................... 17

2.4 Responsabilidade contratual e extracontratual............................................... 19

2.5 Obrigação de meio e de resultado................................................................20

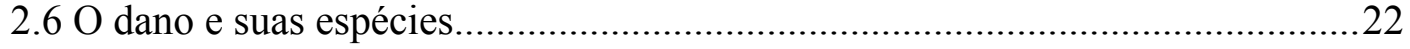

2.7 Culpa lato sensu, dolo e culpa stricto sensu................................................2

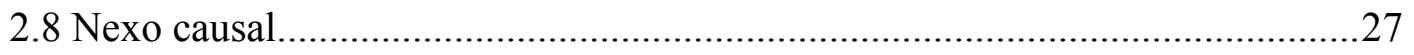

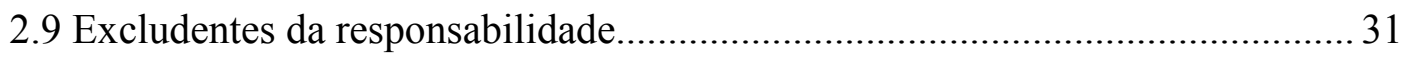

2.10 A importância da prova na apuração dos fatos................................................. 35

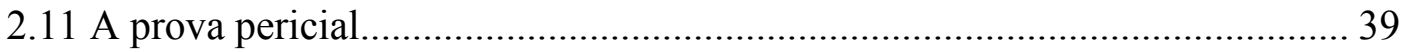

2.12 Procedimentos da perícia e elementos do laudo.......................................... 42

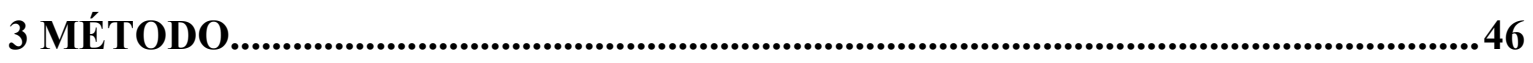

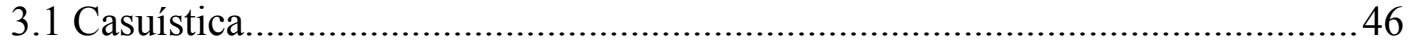

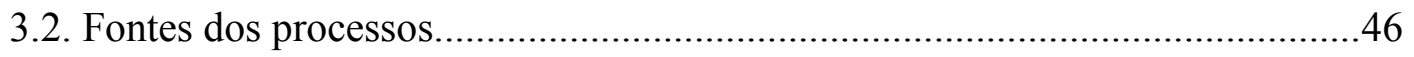

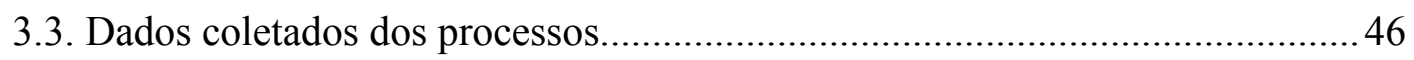

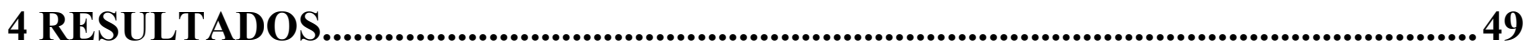

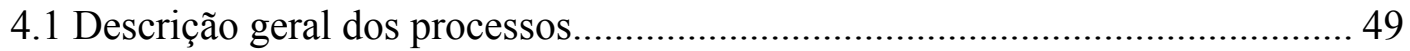

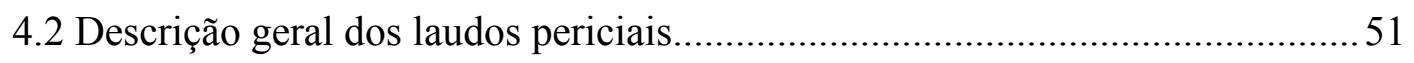

4.3 Elementos específicos constantes dos laudos.............................................52 
5 DISCUSSÃO.

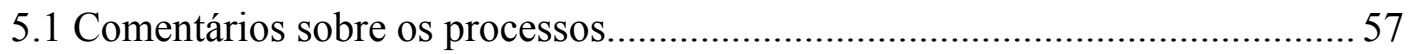

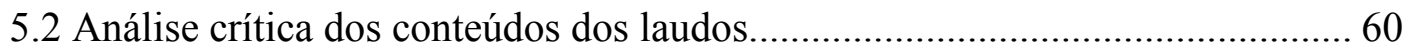

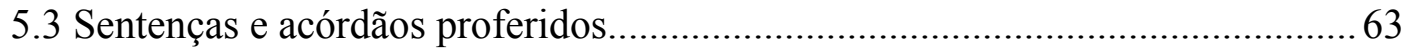

5.4 A questão da especialização dos peritos...........................................................65

5.5 Observações e sugestões relativas à elaboração dos laudos periciais.................66

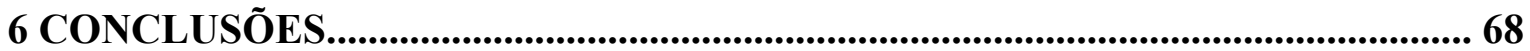

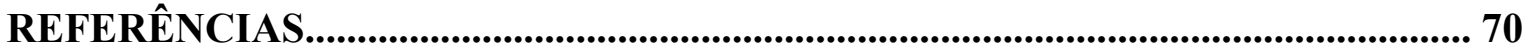

APÊNDICE - PROCESSOS ANALISADOS.............................................................75 


\section{INTRODUÇÃ̃o}

\subsection{Apresentação do tema}

O número de demandas judiciais e administrativas contra profissionais da medicina e estabelecimentos de saúde tem crescido significativamente nos últimos anos.

As melhores condições de saneamento básico, prevenção de doenças e o próprio avanço da ciência médica contribuíram para o aumento da população e da expectativa de vida. Conseqüentemente, o número de médicos e de pacientes também aumentou.

Entretanto, vem se observando uma despersonalização das relações entre médico e paciente. Antigamente, as cidades eram menores e os médicos eram vistos como "profisssionais de família". Sua autoridade e posição social eram incontestáveis.

Na opinião de França (1994, p. 234), as relações entre os pacientes e os "médicos de família" foram substituídas por um relacionamento por vezes frio e impessoal, principalmente nas grandes cidades.

Citando Strauss, França registra que:

Em lugar do velho estilo de cabeceira, o médico de hoje em dia parece depender mais de um formidável aparato instrumental, que salva vidas perdidas por seus predecessores. A imagem do pai foi substituída pelo técnico especializado (S. A. Strauss - "Negligência Médica", in Documenta Geigy, trad. do A., Basiléia, 1971, pág. 4).

Pondera ainda este autor que a imagem de autoridade e conhecimento indiscutíveis do médico praticamente não existe mais. Atualmente ele é considerado um profissional que ganha a vida como outro qualquer, devendo em razão disso responder pelos erros que vier a cometer. Um paciente lesionado ou insatisfeito possui uma disposição muito maior de demandar contra um técnico distante e impessoal do que contra um amigo e conhecido da família.

Com o surgimento de novas especialidades e técnicas, o número de procedimentos médicos tem aumentado. No passado, os médicos se limitavam a diminuir o sofrimento do paciente e as intervenções cirúrgicas eram raras. Hoje as especialidades médicas chegam a dezenas (em 2006/2007 eram reconhecidas 53 especialidades médicas e 54 áreas de 
atuação pelo Conselho Federal de Medicina, Associação Médica Brasileira e Comissão Nacional de Residência Médica) ${ }^{1}$.

Tal especialização vem contribuindo para transformar alguns médicos em meros profissionais técnicos. De acordo com Moraes (2003, p. 433):

\begin{abstract}
A crescente dependência da assistência médica de uma tecnologia complexa acelerou a tendência para a especialização e reforçou a propensão dos médicos de tratar partes específicas do corpo, esquecendose de cuidar do paciente como um ser total.
\end{abstract}

Este autor afirma ainda que a prática da medicina tornou-se progressivamente despersonalizada, destacando que "de 30 a 50 por cento dos casos de hospitalização atuais são clinicamente desnecessários".

$\mathrm{O}$ aumento dos casos de erro médico também está relacionado à sobrecarga de trabalho a que estão submetidos os profissionais da área. Pesquisa realizada pelo Cremesp em $2007^{2}$ revelou que os médicos paulistas cumprem carga horária excessiva e acumulam múltiplos empregos.

Na média, os médicos paulistas trabalham 52 horas por semana, sendo que $30 \%$ destes profissionais afirmam trabalhar mais de 60 horas semanais. O valor médio declarado para consulta particular é de $\mathrm{R} \$ 145,00$, enquanto o valor médio da consulta paga pelo plano de saúde é de R\$30,00.

A insuficiência de profissionais em hospitais públicos e os baixos valores pagos pelos convênios particulares podem fazer com que os médicos reduzam o tempo das consultas, tornando-as por vezes superficiais. No caso das cirurgias, muitas delas são realizadas em seqüência e sem o necessário descanso, o que aumenta a possibilidade de erros.

\footnotetext{
${ }^{1}$ CONSELHO REGIONAL DE MEDICINA DO ESTADO DE SÃO PAULO. Especialidades médicas no Estado de São Paulo. São Paulo, 2008.

${ }^{2}$ CONSELHO REGIONAL DE MEDICINA DO ESTADO DE SÃO PAULO. O trabalho do médico no Estado de São Paulo. São Paulo, 2007.
} 


\subsection{Caracterização do problema}

O tema apresentado foi escolhido em razão das dificuldades atuais que os operadores do direito enfrentam.

Como mencionado, o número de ações judiciais vem crescendo ano a ano, sendo que a estrutura do Poder Judiciário não acompanha este aumento por causa da escassez de recursos materiais e humanos. Em conseqüência disso, cada juiz tem um número maior de processos para examinar, implicando no sacrifício do tempo destinado a cada um.

Outro ponto de reflexão é que o desenvolvimento da tecnologia vem criando novos procedimentos, métodos, técnicas e conceitos, o que exige constante atualização dos profissionais de cada área e gera dificuldades para aqueles que precisam aprender e analisar termos técnicos e específicos.

$\mathrm{Na}$ prática jurisdicional, verifica-se que o número de profissionais habilitados e voltados para a perícia é inferior ao necessário. Em cidades pequenas, muitas vezes não há como se nomear como perito outro médico residente na mesma cidade, seja porque existe a chance de ser conhecido das partes do processo, seja porque nem sempre se encontram profissionais de todas as áreas de especialização.

Para tentar resolver estas dificuldades, é comum buscar peritos em outras cidades ou nomear profissionais pertencentes a órgãos públicos municipais ou estaduais. No Estado de São Paulo, em 1970 foi criado o Instituto de Medicina Social e de Criminologia de São Paulo (IMESC), tendo como suas principais atribuições a realização de perícias e exames médicos requisitados pelas autoridades competentes (juízes de direito, delegados, promotores de justiça, procuradores do estado e defensores públicos, entre outros).

Embora o IMESC possua em seus quadros profissionais de diversas áreas, o volume de trabalho é elevado, a ponto de afetar não apenas o tempo necessário para a realização do exame, como também para entrega dos laudos. Em 1995, o tempo médio de espera para a realização de um simples exame de paternidade por DNA era de 25 meses, estando atualmente em 12 meses $^{3}$. Após a realização do exame, as partes devem aguardar ainda a entrega do laudo, o que pode demorar mais alguns meses.

\footnotetext{
${ }^{3}$ Home page do Governo do Estado de São Paulo. Disponível em: $<$ http://www.justica.sp.gov.br/Modulo. asp?Modulo=111 $>$.
} 
Existem também poucas obras na doutrina brasileira a respeito da perícia que visa apurar se houve erro médico. A matéria envolve, além de todas as disciplinas médicas, ao menos cinco campos do Direito: Civil, Penal, Processual Civil, Processual Penal e Medicina Legal, os quais devem ser estudados em conjunto para se chegar a uma melhor compreensão das questões abordadas.

\subsection{Objetivos e aspectos a serem abordados}

A proposta deste trabalho é fazer uma apreciação crítica dos laudos periciais realizados em ações judiciais de responsabilidade civil por alegado erro médico.

A prova pericial deve orientar o julgador para que este possa fixar os limites da responsabilidade do médico, respondendo adequadamente as questões discutidas no processo, bem como trazendo ao juiz os elementos que o perito considerar úteis ou necessários para auxiliar em suas decisões.

A análise será feita descrevendo-se as técnicas de elaboração dos laudos, fazendo-se críticas sobre se eles cumpriram sua função de forma adequada e, por fim, propondo instrumentos para seu aperfeiçoamento.

Concomitantemente, serão examinados outros pontos considerados relevantes nas ações judiciais desta espécie, os quais serão apresentados nas seções de metodologia, descrição dos resultados e discussão. 


\section{REVISÃO DA LITERATURA}

\subsection{O erro médico no mundo e no Brasil}

Em alguns países o número de denúncias e demandas contra médicos ainda é baixo, como por exemplo na Suécia e em Portugal (Kfoury Neto, p. 56), onde a classe médica possui grande respeitabilidade.

Já em países como os Estados Unidos, ocorre o oposto: trata-se se uma sociedade com um número elevado de advogados, voltada para a geração e resolução judicial de conflitos, o que ocasiona um grande número de pedidos de indenizações.

Kfoury Neto (op. cit., p. 58-59) menciona que os americanos gastam mais do que qualquer outro país do mundo com processos envolvendo a prática médica. Nos últimos anos decisões milionárias tornaram-se comuns.

A justiça de Estados como Pennsylvania (1999) e Mississipi (2002) chegou a fixar indenizações de cem milhões de dólares para casos de medical malpractice e o problema assumiu proporções de crise.

O professor França (1994, p. 235), em suas considerações, salienta que "nos Estados Unidos, realizou-se uma enquete e apurou-se que um bom número de demandantes questionava, não contra o médico, mas contra a companhia de seguros responsável”. Os prêmios do seguro de responsabilidade civil profissional dos médicos e hospitais cresceram de forma insuportável, levando muitos médicos norte-americanos a se aposentarem precocemente ou abandonarem a profissão.

No Brasil, a divulgação de dispositivos da Constituição de 1988 pelos meios de comunicação, aliada à criação de leis especiais como o Código de Defesa do Consumidor, o Estatuto da Criança e do Adolescente e o Novo Código Civil, geraram um fortalecimento da cidadania e um maior esclarecimento da população. Isto provocou um sensível aumento no número de denúncias por erro médico, gerando demandas administrativas e judiciais. 
Estudo realizado pelo Conselho Regional de Medicina do Estado de São Paulo (Cremesp) em $2007^{4}$ demonstrou que, nos últimos sete anos, o número de médicos denunciados naquele órgão aumentou $75 \%$ e o número de processos administrativos cresceu $120 \%$. Verificou-se que $35 \%$ das denúncias e $43 \%$ dos processos contra médicos estão relacionados à suposta má prática profissional (negligência, imprudência ou imperícia).

No mês de outubro de 2001 havia no Estado de São Paulo 2.800.910 ações cíveis em andamento (ações que ainda não foram julgadas ou na fase de execução). Já no mês de setembro de 2009 este número era de 4.922 .482 ações, ou seja, um aumento de 75,74\% em apenas oito $\operatorname{anos}^{5}$. As ações judiciais por erro médico também têm aumentado, juntamente com o número de ações em geral.

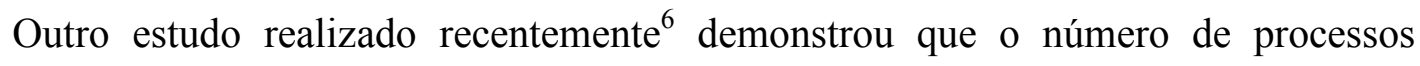
judiciais por erro médico que chegaram ao Superior Tribunal de Justiça, última instância de recurso em matéria de legislação federal, passou de 23 no ano de 2001 para 360 em outubro de 2008.

\subsection{Campos de apuração da responsabilidade por erro médico}

A responsabilização do médico por erros cometidos no exercício da profissão pode ser administrativa, civil ou penal. Trata-se de campos relativamente independentes, ou seja, a decisão formulada em um deles pode ou não influenciar no resultado dos demais. Os procedimentos em cada uma destas esferas são instaurados e tramitam independentemente.

A responsabilidade administrativa é apurada pelos órgãos de regulação da atividade profissional, quais sejam, o Conselho Regional de Medicina (CRM) de cada Estado e, como autoridade superior, o Conselho Federal de Medicina (CFM) localizado em Brasília. A denúncia normalmente é feita pela parte interessada. Realiza-se uma sindicância e, se

\footnotetext{
${ }^{4}$ CONSELHO REGIONAL DE MEDICINA DO ESTADO DE SÃO PAULO. Denúncias e processos relacionados ao exercício profissional da medicina no Estado de São Paulo no período de 2000 a 2006. São Paulo, 9 out. 2007.

${ }^{5}$ Movimento Judiciário de Primeira Instância publicado pela Corregedoria Geral da Justiça do Estado de São Paulo, disponível mensalmente no Diário da Justiça em: www.dje.tj.sp.gov.br.
} 
forem constatados indícios de infração ética, consistente na violação de algum artigo do Código de Ética Médica, instaura-se um processo ético-profissional. Após a apresentação das provas de acusação e de defesa é realizado um julgamento pelos próprios conselheiros e o profissional pode sofrer diversas sanções, das quais a mais grave é a cassação do registro profissional, que impede o exercício da medicina.

Em 24 de setembro de 2009 foi publicada no Diário Oficial da União a Resolução n 1931/2009 do CFM, que instituiu um novo Código de Ética Médica em substituição ao vigente desde 1988. O novo código é composto de 25 princípios fundamentais do exercício da Medicina, 10 normas diceológicas (direitos profissionais), 118 normas deontológicas (deveres profissionais) e quatro disposições gerais.

As responsabilidades civil e criminal são apuradas pelo Poder Judiciário. A primeira decorre da existência de um dano passível de ser reparado financeiramente, enquanto a segunda ocorre quando o médico pratica um ato expressamente previsto na legislação de natureza penal.

Observe-se que, mesmo não havendo ilícito civil ou conduta criminosa, pode subsistir prática de conduta que viole as disposições éticas fixadas pelo Conselho Federal de Medicina.

O ilícito penal, que pode ser classificado como crime ou contravenção, deve estar previsto e descrito literalmente na lei, em razão do princípio constitucional da legalidade.

A condenação definitiva pela prática de ilícito penal leva, na esfera civil, à certeza da obrigação de reparar o dano, discutindo-se apenas o valor da indenização devida. Todavia, a absolvição na justiça criminal não significa a absolvição civil nem administrativa.

A responsabilidade civil é relativamente independente da criminal, sendo que a decisão penal somente terá efeito civil quando tiver decidido a respeito da inexistência material do fato ou afastado completamente a autoria por parte do médico ${ }^{7}$.

\footnotetext{
${ }^{6}$ SANT'ANNA, Emilio. Número de ações sobre erro médico no STJ cresce 17 vezes em 7 anos. O Estado de São Paulo, São Paulo, 13 nov. 2008. Disponível em: < $\underline{\text { http://www.estadao.com.br/estadaodehoje/ }}$ 20081113/not_imp276831,0.php >. Acesso em: 20 nov. 2008.
} 


\subsection{Responsabilidade objetiva e subjetiva}

A responsabilidade civil se fundamenta na obrigação de um agente em reparar um dano causado a outrem. No caso da responsabilidade por erro médico, o dano deve ser causado em razão do exercício dessa função, não apenas por parte do médico profissional liberal, como também dos estabelecimentos de saúde.

O professor Alcântara ${ }^{8}$ registra que:

O fundamento da responsabilidade civil está na alteração do equilíbrio social, produzida por um prejuízo causado a um de seus membros. $\mathrm{O}$ dano sofrido por um indivíduo preocupa todo o grupo porque, egoisticamente, todos se sentem ameaçados pela possibilidade de, mais cedo ou mais tarde, sofrerem os mesmos danos, menores, iguais e até maiores (apud FRANÇA, 1994, p. 255).

As duas principais teorias que procuram explicar os fundamentos da responsabilidade civil são denominadas objetiva e subjetiva.

A responsabilidade subjetiva se fundamenta na teoria da culpa. O dever de indenizar neste caso pressupõe três requisitos: a demonstração da culpa do profissional, a existência do dano e o nexo causal entre dano e culpa. Esta é a teoria adotada como regra geral pelo Código Civil ${ }^{9}$.

Já a responsabilidade objetiva possui suporte na teoria do risco. Segundo esta teoria, todo aquele que exerce uma atividade econômica deve assumir a responsabilidade de reparar os danos decorrentes do exercício dessa atividade, independentemente da existência de culpa.

Enquanto a responsabilidade subjetiva ou com culpa é a regra, a responsabilidade objetiva ou sem culpa somente é admitida nos casos expressamente previstos em lei ${ }^{10}$.

\footnotetext{
${ }^{7}$ Art. 935 do CC: “A responsabilidade civil é independente da criminal, não se podendo questionar mais sobre a existência do fato, ou sobre quem seja o seu autor, quando estas questões se acharem decididas no juízo criminal."

8 ALCÂNTARA, Hermes Rodrigues de. Responsabilidade Médica, José Konfino Editor, Rio de Janeiro, 1971.

${ }^{9}$ Art. 186 do CC: “Aquele que, por ação ou omissão voluntária, negligência ou imprudência, violar direito e causar dano a outrem, ainda que exclusivamente moral, comete ato ilícito."

${ }^{10}$ Art. 927 do CC: "Aquele que, por ato ilícito (arts. 186 e 187), causar dano a outrem, fica obrigado a repará-lo. Parágrafo único. Haverá obrigação de reparar o dano, independentemente de culpa, nos casos especificados em lei, ou quando a atividade normalmente desenvolvida pelo autor do dano implicar, por sua natureza, risco para os direitos de outrem."
} 
Couto Filho e Souza (2002, p. 11) ensinam que:

Convém elucidar que na responsabilidade objetiva pode até haver o elemento culpa; este pode até estar presente, sendo, porém, irrelevante para a análise da obrigação de indenizar que, por seu turno, existirá, desde que presente o nexo causal. Portanto, na responsabilidade objetiva não é admissível qualquer discussão atinente à teoria da culpa, sendo certo que o autor da conduta ilícita só se libera da obrigação de indenizar no caso de se encontrar inserido numa das causas de exclusão do nexo causal, quais sejam, caso fortuito, força maior, fato exclusivo da vítima ou de terceiro.

A responsabilidade objetiva também é adotada no artigo 14 da Lei $n^{\circ}$ 9.078/90 (Código de Defesa do Consumidor), que dispõe que os fornecedores de serviços (caso dos hospitais, clínicas e planos de saúde) respondem pela reparação dos danos causados aos consumidores por defeitos relativos à prestação dos serviços, independentemente da demonstração de culpa.

Neste caso, o dever de indenizar pressupõe apenas o defeito no serviço (desde que esse defeito não decorra de risco inerente ao serviço), a existência do dano e o nexo causal que vincula o serviço ao dano. Observe-se que o autor da ação não precisa comprovar o defeito no serviço, e sim o réu é quem deve comprovar a inexistência deste.

Existe, porém, uma ressalva no $\S 4^{\circ}$ do mesmo artigo, o qual prevê que a responsabilidade pessoal dos profissionais liberais só pode ser declarada mediante a verificação de culpa. Aplica-se a teoria da responsabilidade subjetiva quando o médico for profissional liberal, abrangendo-se no caso a pessoa física.

O mesmo fato, então, pode gerar duas hipóteses de responsabilidade, como leciona Benjamin (1991, p. 80):

O Código (do Consumidor) é claro ao asseverar que só para a 'responsabilidade pessoal' dos profissionais liberais, é que se utiliza o sistema alicerçado em culpa. Logo se o médico trabalhar em hospital responderá apenas por culpa, enquanto a responsabilidade do hospital será apreciada objetivamente.

As responsabilidades do médico e do fornecedor de serviços são solidárias (artigos 186 e 942 do Código Civil e artigos $7^{\circ}$, parágrafo único, 25, § $1^{\circ}$ e 34 do CDC). Sendo assim, o autor da ação pode escolher se irá processar somente um deles ou ambos, cabendo 
ao réu condenado o direito de regresso contra o outro, caso entenda que a culpa foi exclusivamente deste.

Em resumo, os requisitos da responsabilidade subjetiva são o dano, a culpa do profissional e o nexo causal que ligue a culpa ao dano. Já os requisitos da responsabilidade objetiva são o dano e o nexo causal que ligue o serviço ao dano (o defeito no serviço é presumido).

\subsection{Responsabilidade contratual e extracontratual}

A obrigação de reparar pode surgir do não cumprimento de um contrato (responsabilidade contratual) ou do cometimento de um ato ilícito (responsabilidade extracontratual).

A responsabilidade extracontratual, também chamada delitual, abrange os fatos ocorridos entre pessoas que não tem nenhuma relação jurídica antecedente, como por exemplo um acidente de trânsito entre um motorista e um ciclista. Observe-se que o termo delito aqui considerado não é apenas o da esfera criminal, abrangendo também o ilícito civil.

Já a responsabilidade contratual é aquela em que existe algum tipo de relação jurídica ou contrato previamente estabelecidos entre as partes envolvidas. O contrato pode assumir duas formas: escrito (em papel ou outro suporte material) ou verbal (quando houver uma combinação entre as partes, sem formalização por escrito).

Em regra, a responsabilidade do médico é contratual, mas pode haver casos de responsabilidade extracontratual. Diniz (2008, p. 299) fornece alguns exemplos:

O médico, p. ex., responderá extracontratualmente quando: a) fornecer atestado falso; b) consentir, podendo impedir, que pessoa não habilitada exerça a medicina; c) permitir a circulação de obra por ele escrita com erros de revisão relativos à dosagem de medicamentos, o que vem a ocasionar acidentes ou mortes; d) não ordenar a imediata remoção do ferido para um hospital, sabendo que não será possível sua melhora nas condições em que o cliente está sendo tratado; e) operar sem estar habilitado para tal; f) lançar mão de tratamento cientificamente condenado, causando deformação no paciente (RT, 180:178). 
$\mathrm{Na}$ responsabilidade extracontratual, da mesma forma que na responsabilidade subjetiva, a vítima deve comprovar o dano, a culpa e o nexo causal que ligue a culpa ao dano.

Já na responsabilidade contratual, a vítima deve comprovar o dano, o descumprimento do contrato e o nexo causal. Descumprido o contrato, a culpa passa a ser presumida, ou seja, considera-se o autor do dano culpado até que ele produza prova em contrário. O efeito é semelhante ao da teoria objetiva (desnecessidade de demonstrar a culpa), porém aqui a responsabilidade continua sendo subjetiva.

Ocorre que, na prática forense, nem sempre a distinção entre responsabilidade contratual e extracontratual é bem estabelecida, ainda mais porque existe uma dificuldade considerável para a vítima provar o descumprimento do contrato de serviços médicos. Rocha (2005, p. 371) observa que:

\begin{abstract}
Por outra parte, não se deve esquecer que muitos autores afirmam que na responsabilidade civil do médico podem concorrer conjuntamente a vertente contratual e extracontratual, pois está claro que o facultativo, além de estar obrigado a cumprir as obrigações derivadas do contrato, tem que observar a mais genérica obrigação de não causar dano a outro (alterum non laedere). Diante disso, existe tendência nos Tribunais a favorecer ao paciente que sofreu o dano, oferecendo-lhe um amplo abanico de possibilidades processuais, como o exercício de ambas ações de forma alternativa, ou a opção por uma ou outra ou, finalmente, aceitando que o paciente se limite a proporcionar os fatos ao julgador para que este aplique as normas que estime mais favoráveis para o prejudicado.
\end{abstract}

\title{
2.5 Obrigação de meio e de resultado
}

Quando o paciente procura o médico e aceita que este efetue determinado procedimento, produz-se um contrato entre as partes. Para que se verifique se houve ou não o cumprimento do contrato, deve-se analisar se este gerou uma obrigação de meio ou de resultado.

Na obrigação de meio, o médico não se compromete a curar o paciente, e sim a usar todos os meios adequados e existentes na ciência médica para tratá-lo. Já na obrigação de resultado, o médico assume o compromisso de atingir um objetivo específico. 
$\mathrm{Na}$ ação indenizatória do primeiro tipo (obrigação de meio), o autor deve provar o descumprimento do contrato (ou seja, a culpa), o dano sofrido e o nexo causal entre eles. A culpa do médico, pela natureza desse tipo de contrato, estará configurada quando os seus serviços tiverem sido prestados fora dos padrões técnicos da sua profissão.

$\mathrm{Na}$ ação de indenização pelo segundo tipo (obrigação de resultado), ocorre culpa presumida quando a cirurgia ou ato médico não atinge o resultado esperado. A vítima deve comprovar apenas o dano e o nexo causal. Para se exonerar, o médico deverá provar a ocorrência de alguma das causas excludentes de responsabilidade, que serão relacionadas adiante.

O contrato médico é tipicamente de meio e não de resultado. Contudo, algumas modalidades geram discussão a respeito da natureza da obrigação gerada, se de meio ou de resultado. Dentre elas, podem-se mencionar: exames laboratoriais e radiológicos, cirurgia estética, odontologia, cirurgia para correção de miopia, transfusão de sangue e outras mais. Serão examinadas aqui as três primeiras modalidades, por apresentarem maior exposição na literatura.

Sobre a cirurgia estética, apontam Couto Filho e Souza (2002, p. 18-19):

Há uma corrente que norteia o entendimento de que a obrigação na cirurgia estética deve ser considerada de resultado e, portanto, aplicável a teoria subjetiva, mas com culpa presumida e, por conseguinte, com a inversão do ônus da prova.

Outra corrente, entrementes, sustenta tratar-se de obrigação de meio, igualmente às demais especializações médicas, tendo em vista que as intervenções cirúrgicas estéticas, da mesma forma que quaisquer outras cirurgias e tratamentos médicos, são suscetíveis às mais diferentes intercorrências que independem do atuar médico.

Com todo o respeito às posições em contrário, nos filiamos à corrente que entende ser a obrigação estética de meio e, conseguintemente, só haverá o dever de indenizar mediante a comprovação de culpa.

Outros autores apontam mais acertadamente que a cirurgia estética pode ser classificada em reparadora e estética propriamente dita. $\mathrm{O}$ mesmo vale para as intervenções odontológicas, que podem ser reparadoras ou puramente estéticas. Veja-se Sebastião (1998, p. 31):

A Medicina plástica (incluída a dentária) desenvolve-se sob dois enfoques distintos: reparadora (tanto a de reconstrução estética para 
restauração, como a complementar, para sanar defeito congênito), e a simplesmente estética, de cunho voluntário e ditada pela vaidade pessoal (também denominada cosmetológica). $\mathrm{Na}$ cirurgia eminentemente reparadora, como já dito, o contrato é o comum (apenas de meios), enquanto que na cirurgia simplesmente estética (e por isso voluntária), o contrato é misto, ou seja, de meios e de resultados.

Com relação à realização de exames de laboratório e radiológicos, entende-se que o mais correto é considerá-los como obrigações de resultado e não de meio, ou seja, quando houver erro no resultado do exame divulgado considera-se que a obrigação não foi cumprida.

Na doutrina de Theodoro Júnior ${ }^{11}$ :

A configuração do contrato de meio é a regra em tema de prestação de serviços médicos. Há, todavia, algumas situações em que a dita prestação se torna obrigação de resultado, tais como na realização de raios $\mathrm{X}$, de exames laboratoriais, de cirurgia plástica puramente estética. A frustração do fim do serviço prestado, in casu, é inadimplemento contratual, que por si só, justifica a responsabilidade indenizatória pelo dano causado ao paciente.

\subsection{O dano e suas espécies}

Nas ações cíveis cabe ao autor expor os danos sofridos em razão da conduta do réu, fazendo em seguida os pedidos que entender suficientes para reparar tais danos. O julgador encontra-se adstrito aos pedidos formulados na petição inicial, conforme os princípios processuais da demanda e da congruência, sendo vedada a prolação de sentença extra, ultra ou infra petita (respectivamente: fora, além ou aquém do pedido) $)^{12}$.

Existem petições iniciais com uma dezena de pedidos e outras que se limitam a apenas um. Alguns advogados chegam a formular pedidos alternativos e outros resumem tudo aos danos morais. Até mesmo a doutrina é bastante variada a respeito, havendo por exemplo quem discorra sobre "dano médico", situando os conceitos de dano material e

11 THEODORO JÚNIOR, Humberto. Aspectos processuais da ação de responsabilidade por erro médico. Revista de Processo, n. 95. 05 dez. 2005. São Paulo: Editora Revista dos Tribunais, 1999.

12 Art. 460 do CPC: "É defeso ao juiz proferir sentença, a favor do autor, de natureza diversa da pedida, bem como condenar o réu em quantidade superior ou em objeto diverso do que lhe foi demandado." 
moral na liquidação (Kfouri Neto, 2007). Diante desta variedade de definições, propõe-se a classificação dos danos em quatro espécies: físicos, estéticos, morais e materiais.

Os danos físicos ou corporais estão relacionados à perda de algum órgão, função ou sentido, invalidez da vítima, agravamento do estado de saúde, etc. A indenização normalmente é pedida em razão do tipo e da extensão da lesão, fixando-se um valor compensatório pela perda sofrida.

Observa-se que os danos físicos podem gerar danos estéticos, morais e materiais, casos em que existirão outras indenizações a serem tratadas separadamente.

Os danos estéticos são caracterizados pela ofensa direta à integridade física da pessoa, causando deformações, marcas ou defeitos. Diniz (2008, p. 80) conceitua o dano estético como:

Toda alteração morfológica do indivíduo que, além do aleijão, abrange as deformidades ou deformações, marcas e defeitos, ainda que mínimos, e que impliquem sob qualquer aspecto um afeiamento da vítima, consistindo numa simples lesão desgostante ou num permanente motivo de exposição ao ridículo ou de complexo de inferioridade, exercendo ou não influência sobre sua capacidade laborativa.

Um dano físico nem sempre produz um dano estético (por exemplo, a pessoa pode sofrer a perda de um órgão interno, função ou sentido e não apresentar cicatriz visível). Por outro lado, todo dano estético consiste em uma afronta ao elemento físico da pessoa.

Existem vários entendimentos sobre a natureza do dano estético. Para alguns autores, os danos estéticos estariam inteiramente compreendidos nos danos morais, já que sua natureza seria essencialmente extrapatrimonial (Tereza Lopes, 2004; Kfouri Neto, 2007 e Diniz, 2008).

Para outros estudiosos, os danos estéticos seriam ou de natureza material ou de natureza moral, não sendo admitidos como espécie autônoma ou cumulativa (Ribeiro, 2003). A Resolução $\mathrm{n}^{0}$ 09, aprovada por unanimidade pelos participantes do IX ENTA (Encontro Nacional dos Tribunais de Alçada), realizado em agosto de 1997, em São Paulo, dispõe: "O dano moral e o dano estético não se cumulam, porque ou o dano estético importa em dano material ou está compreendido no dano moral”.

Art. 535 do CPC: "Cabem embargos de declaração quando: [...] II - for omitido ponto sobre o qual devia pronunciar-se o juiz ou tribunal." 
Uma terceira corrente sustenta tratar-se de uma espécie autônoma de dano, podendo por este motivo ser cumulada tanto com os danos materiais como morais (Almeida, s.d. e Barros, 2001). Veja-se neste sentido a súmula $n^{0} 387$ do STJ, editada em agosto de 2009: "É lícita a cumulação das indenizações de dano estético e dano moral".

Dando continuidade às espécies de dano, existem os danos morais, que se caracterizam pela angústia, dor e sofrimento causados à pessoa. Por exemplo, um exame que diagnostica erroneamente uma doença grave e por isso causa sofrimento ao paciente. Neste caso não há qualquer lesão física ou estética, mas pode haver dano moral.

Finalmente, existem os danos materiais, chamados também de patrimoniais. Eles podem decorrer dos danos físicos ou estéticos sofridos, bem como de quaisquer falhas ou defeitos na prestação dos serviços médicos.

Os danos materiais são divididos em duas subespécies: danos emergentes e lucros cessantes. Os danos emergentes consistem na soma dos prejuízos patrimoniais que a vítima sofreu em razão do ato ilícito. Por exemplo: devolução do valor pago pela operação ou diagnóstico errado, novos exames para diagnosticar o mal causado ou agravado pelo erro médico, pagamento de tratamento médico e psicológico, cirurgias plásticas, próteses, medicamentos e outros.

Já os lucros cessantes consistem naquilo que a vítima deixou ou deixará de receber em razão do ato ilícito. Normalmente consistem no pagamento de uma pensão pelo tempo em que a pessoa ficou sem trabalhar ou, no caso de incapacidade, pelo restante da vida.

É importante acrescentar que, após a exposição dos danos sofridos, em regra os autores formulam seus pedidos para reparação. Cada tipo de dano pode ensejar um ou mais pedidos de reparação, sendo que os valores pedidos a título de danos materiais compreendem, por exemplo: reembolso de gastos, pagamento de tratamento médico, tratamento psicológico, cirurgias plásticas, próteses, medicamentos, lucros cessantes, pensão e outros.

Já com relação aos danos físicos, estéticos e morais, trata-se de valores que compensem, respectivamente: a perda de órgão, sentido ou função; a deformidade; a dor e sofrimento moral. 


\subsection{Culpa lato sensu, dolo e culpa stricto sensu}

Como visto, em grande parte dos casos a apuração de conduta irregular por parte do médico, seja ilícito civil, penal ou infração administrativa, exige a demonstração de que o profissional agiu com culpa e que em razão desta culpa foi causado algum tipo de dano ao paciente.

A culpa em sentido amplo (lato sensu) possui duas modalidades: dolo e culpa em sentido estrito (stricto sensu). Dolo é a vontade livre e consciente de provocar determinado resultado. Por exemplo, o médico que intencionalmente lesiona um paciente ou provoca um aborto fora das hipóteses autorizadas pela lei.

No âmbito penal, a distinção entre dolo e culpa stricto sensu é importante para classificar a conduta como crime doloso ou culposo. Já nos âmbitos civil ou administrativo, pode servir para avaliar o grau de responsabilização do profissional.

A culpa stricto sensu divide-se em três modalidades: negligência, imprudência e imperícia.

Negligência é a desatenção ou falta de cuidado razoável. Para Rocha (2005, p. 379):

A negligência consiste na omissão da diligência devida, na omissão da conduta esperada. É a falta de cuidados ou de atenção daquele que, embora possuidor dos conhecimentos indispensáveis, não age com as precauções ou cuidados devidos, levando a resultados prejudiciais

França (1994, p. 243) afirma que “a negligência caracteriza-se pela inação, indolência, inércia, passividade. É a falta de observância aos deveres que as circunstâncias exigem. É um ato omissivo".

Um exemplo bastante comum de negligência é o esquecimento de um corpo estranho no corpo do paciente em decorrência de uma cirurgia realizada. Também pode ser considerado negligente o médico que prescreve tratamento inadequado ou que abandona o doente.

Igualmente responde por negligência o médico chefe de equipe, o qual é responsável pelos atos lesivos praticados no paciente pelos auxiliares que se encontram sob suas ordens ou instruções. Sebastião (1998, p. 31) explica esta hipótese: 
O médico também responde pelos seus subordinados ou auxiliares, com ou sem vínculo de emprego (estudantes de Medicina, enfermeiros, funcionários, etc.), se estes causarem danos aos pacientes. É a denominada culpa in eligendo, ou seja, má escolha ou culpa in vigilando, pela ausência de fiscalização.

Imprudência é a assunção de riscos de forma desnecessária. Rocha (2005, p. 378) afirma que "a imprudência médica é conceituada como aquela conduta que não contenha a cautela necessária e devida para o ato médico realizado. A conduta imprudente consiste em agir o sujeito sem as cautelas necessárias, com açodamento e arrojo". Na definição de França (1994, p. 243) “imprudente é o médico que age sem a cautela necessária. É aquele cujo ato ou conduta são caracterizados pela intempestividade, precipitação, insensatez ou inconsideração. A imprudência tem sempre caráter comissivo”.

Segundo um exemplo fornecido por estes autores, "imprudente é o cirurgião que, podendo realizar uma operação por um método conhecido, abandona essa técnica e, como conseqüência, acarreta para o paciente um resultado danoso”. Também é imprudente o médico que realiza uma cirurgia em tempo menor do que aquele que normalmente seria necessário ou pratica uma cirurgia de risco com equipamentos não adequados ou não esterilizados.

Por fim, a imperícia é a falta de habilidade técnica para exercer determinada atividade ou realizar determinado ato. Rocha (op. cit., p. 375) a conceitua como “incompetência, inexperiência, inaptidão técnica, despreparo profissional. Se trata de uma falta de conhecimentos profissionais ou de uma aplicação deficiente dos conhecimentos da profissão". França (op. cit., p. 251) a define como "a falta de observação das normas, por despreparo prático ou por insuficiência de conhecimentos técnicos. É a carência de aptidão, prática ou teórica, para o desempenho de uma tarefa técnica”.

É imperito o médico que realiza uma cirurgia sem conhecimentos suficientes de anatomia, vindo a lesar um órgão do paciente. Também é imperito o profissional que fornece diagnóstico errado ou que, a pretexto de fazer uma cirurgia meramente estética, acaba causando deformidade no paciente. 


\subsection{Nexo causal}

Na lição de Melo (2008, p. 46), "O nexo causal é a relação de causa e efeito que liga o dano ao causador (responsabilidade subjetiva) ou ao responsável pela atividade (responsabilidade objetiva)".

Aproveitando este conceito, lembra-se que, tanto na responsabilidade objetiva como na que tiver como fundamento uma obrigação de resultado, a vítima precisa apenas comprovar o dano e o nexo causal que ligue o evento danoso ao autor do fato, daí sua grande importância.

O estabelecimento do nexo causal pode parecer simples à primeira vista, porém é uma das matérias que mais geram polêmicas e discussões no mundo jurídico. Os conceitos de causa e efeito possuem suas origens na própria natureza e suscitam discussões profundas também no terreno da Filosofia.

Em primeira e superficial análise, causa é um acontecimento que gera determinado resultado. Raciocinando-se inversamente, para que um fato seja considerado causa deve-se verificar se, não ocorrendo tal fato, o resultado também não ocorreria.

Entretanto, diante de uma multiplicidade de causas, nem sempre é determinar qual ou quais delas foram relevantes ou suficientes para gerar o resultado. Melo (op. cit., p. 47), citando o magistrado Sérgio Cavalieri filho, observa que:

\footnotetext{
"Quando o resultado decorre de um fato simples, a questão não oferece a menor dificuldade, porquanto a relação de causalidade é estabelecida de maneira direta entre o fato e o dano". Como, nem sempre, nas relações jurídicas, as coisas se mostram com tamanha simplicidade, acresce o ilustre autor que "o problema torna-se um pouco mais complexo nas hipóteses de causalidade múltipla, isto é, quando há uma cadeia de condições, várias circunstâncias concorrendo para o evento danoso, e temos que precisar qual delas é a causa real do resultado".
}

As causas múltiplas, também chamadas de concausas, podem ser sucessivas ou concomitantes. Na primeira hipótese, uma causa produz danos sucessivos, sendo que os últimos são produzidos pelos antecedentes. Já na segunda hipótese, diversas causas concorrem para produzir um único dano. Podem ocorrer situações em que diversas causas produzem diversos danos sucessivos, gerando uma dificuldade ainda maior na apuração. 
Existem diversas teorias que buscam resolver a questão da causalidade múltipla. Dentre elas, foram escolhidas as três mais importantes, quais sejam: a da equivalência das condições, a da causalidade adequada e a dos danos diretos e imediatos.

A teoria da equivalência das condições, também chamada teoria da equivalência dos antecedentes ou teoria da conditio sine qua non considera como causa qualquer das condições que concorreu para o resultado, não se questionando qual delas foi mais ou menos eficaz para a produção do evento danoso. A equivalência significa que, suprimida qualquer uma destas causas, o evento danoso não se verificaria.

A principal crítica a esta teoria é que ela permite uma regressão do nexo causal ao infinito. Assim, o responsável pelo dano causado em um acidente de trânsito não seria apenas o motorista que dirigiu o veículo com imprudência, mas também quem lhe vendeu o automóvel, quem o fabricou e assim por diante, o que pode gerar conclusões absurdas.

Apenas a título de ilustração, a teoria da conditio sine qua non é adotada pelo Código Penal em seu artigo $13^{13}$, entretanto verificar que alguém causou o resultado não basta para ensejar a responsabilidade penal. É necessário ainda que esteja presente o elemento subjetivo (dolo ou culpa) nessa conduta que foi causa do evento.

Voltando ao tema da responsabilidade civil, a segunda teoria é a da causalidade adequada, segundo a qual não existe equivalência entre as condições que concorrem para o evento, devendo ser considerada causa apenas aquela que for decisiva e adequada para a produção do resultado.

Nos dizeres de Couto Filho e Souza (2008, p. 9-10):

Em sede de responsabilidade civil, não há que se falar em equivalência das condições, sendo que será a causa do resultado, dentre as tantas condições que existam apontando para a produção do dano, somente aquela que tiver interferência decisiva na produção do evento, sem olvidar, no entanto, que deve ser realizada a análise em abstrato, ou seja, se a condição determinante para a obtenção do resultado danoso é, em abstrato, adequada à produção do mesmo.

Por derradeiro, a teoria do dano direto e imediato, também chamada de teoria da relação causal imediata ou teoria da interrupção do nexo causal, considera como causa o fator que tenha produzido diretamente e mais proximamente o resultado, de modo que a causa mais próxima exclui a mais remota. 
Couto Filho e Souza, em outra obra (2002, p. 6) entendem que:

No dizer da melhor doutrina, a jurisprudência ainda que muitas vezes denominando, em suas decisões, o termo "causalidade adequada" emprega, em verdade, a teoria do dano direto e imediato para apurar o nexo de causalidade ou sua existência.

O importante, todavia, é que, utilizando-se da denominação de teoria da interrupção do nexo causal - caso do Supremo Tribunal Federal - ou da teoria da causalidade adequada - caso do Superior Tribunal de Justiça e do Tribunal de Justiça do Estado do Rio de Janeiro -, ambas posições doutrinárias exigem, afinal, a "causalidade necessária entre a causa e o efeito danoso para o estabelecimento da responsabilidade civil".

Como se pode perceber a respeito deste tema, mais do que a aplicação de regras com descrições abstratas, o melhor é que o julgador examine com eqüidade e bom senso todas as circunstâncias, procurando em cada caso a decisão mais justa.

Para ilustrar a dificuldade de se compreender e estabelecer o nexo causal, veja-se um caso interessante da jurisprudência ${ }^{14}$. A autora narrou na petição inicial ter sofrido de vômitos, calafrios, febre e dores abdominais, vindo a ser internada em estabelecimento hospitalar. Foram realizados exames de tomografia e ressonância magnética na clínica ré (estabelecimento diverso da internação), sendo que o primeiro exame diagnosticou erroneamente a existência de "clipes metálicos" no abdômen da autora e o segundo não relatou a situação do apêndice. Em razão destes dois exames, a equipe médica que atendia a autora diagnosticou um processo imuno-alérgico aos "clipes" e deu-lhe alta hospitalar. Após vinte e sete dias e agravamento dos sintomas, a autora realizou exame de radiografia (também na clínica ré), o qual diagnosticou apendicite, levando à operação em caráter de urgência.

Com base no alegado erro de diagnóstico, a autora formulou os seguintes pedidos: a) pagamento de lucros cessantes em razão da sua incapacidade absoluta para o trabalho e de seu companheiro, por um período de 27 dias; b) dano moral de cinco mil saláriosmínimos; c) reembolso do pagamento dos exames realizados na clínica ré; d) pagamento dos honorários médicos da cirurgia de apendicite.

\footnotetext{
${ }^{13}$ Art. 13 do CP: "O resultado, de que depende a existência do crime, somente é imputável a quem lhe deu causa. Considera-se causa a ação ou omissão sem a qual o resultado não teria ocorrido."

${ }^{14}$ Superior Tribunal de Justiça, Resp n ${ }^{\circ}$ 594.962/RJ, Terceira Turma, Relator Min. Antonio de PÁDUA RIBEIRO, j. em 09.11.2004, publ. em 17.12.2004.
} 
Após os procedimentos normais (oitiva de testemunhas, perícia, etc.) a ação foi julgada improcedente. Entendeu a MM. a Juíza de Direito que realmente houve erro por parte da ré no laudo que constatou a presença dos "clipes metálicos", mas que não se tratava de erro grosseiro. E que, além disso, inexistia nexo de causalidade entre os males apresentados pela autora e o laudo elaborado pela clínica ré.

A apelação interposta pela autora foi provida por maioria, ficando reconhecido o erro grosseiro de diagnóstico que causou a falta de tratamento médico adequado à paciente, levando-a a risco de vida. Afirmou que os danos materiais e morais ficaram demonstrados e reconheceu a obrigação da ré ao amplo ressarcimento de tais danos. O recurso foi provido para julgar inteiramente procedente a ação.

A clínica ré, agora vencida, interpôs embargos infringentes que, por maioria, foram acolhidos. O novo acórdão entendeu que a prova pericial e testemunhal demonstraram a inexistência do nexo causal, pois nenhum médico afirmou que o diagnóstico de apendicite tenha sido mascarado pelo resultado errôneo do primeiro laudo. Sustentou que a teoria aplicada em nosso ordenamento jurídico é a do dano direto e imediato, também denominada teoria da interrupção do nexo causal. Os embargos foram providos para julgar improcedente a ação.

A autora interpôs Recurso Especial no Superior Tribunal de Justiça. O relator do recurso entendeu ser incontroverso que houve erro no laudo da tomografia ao afirmar existirem "clipes metálicos" no abdômen da autora. O novo exame realizado a pedido médico, a ressonância magnética, foi omisso quanto ao exame anterior e também quanto à visualização ou não do apêndice da autora. Afirmou que o erro foi grosseiro e impediu que a autora fizesse tratamento adequado, levando-a a sofrer risco de vida, além de ocasionarlhe sofrimento físico e moral. Reconheceu que a responsabilidade da clínica ré é objetiva, sendo a obrigação de resultado e não de meio.

Procedeu-se então ao exame detalhado do nexo causal entre a conduta da ré e cada um dos danos alegados pela autora:

a) com relação aos danos morais, o defeito no laudo médico causou substancial atraso no correto diagnóstico da autora, com evitáveis sofrimentos para ela, motivo pelo qual se evidenciou o nexo de causalidade entre o serviço médico defeituoso e os danos extrapatrimoniais sofridos pela autora;

b) com relação aos lucros cessantes referentes ao período no qual a autora e seu cônjuge ficaram sem trabalhar, o diagnóstico correto da autora somente seria possível com 
a laparoscopia. Mesmo se inexistisse o defeito no laudo da tomografia, o diagnóstico da apendicite não ocorreria na data da elaboração daquele laudo, ou seja, mesmo se o laudo tivesse correto, transcorrer-se-ia um intervalo até a constatação de necessidade de laparoscopia para a definição do diagnóstico da autora. Determinou-se então que fosse realizada liquidação de sentença para se aferir qual o período de tempo razoável (dentro desses vinte e sete dias) para que um médico, se não houvesse o defeito no laudo elaborado pela ré, chegasse à conclusão de necessidade de laparoscopia;

c) quanto à devolução do dinheiro gasto com a tomografia da qual decorreu o laudo defeituoso, reconheceu ser nítido o nexo de causalidade, pois a autora arcou com o custo do exame sem a contraprestação legitimamente por ela esperada, qual seja, a elaboração de um laudo médico sem defeitos;

d) quanto ao pagamento da ressonância magnética da pelve e da radiografia de abdômen, a autora não demonstrou o nexo de causalidade entre o defeito na tomografia e a necessidade de realização desses exames posteriores. Os indícios existentes no processo sugeriram exatamente o contrário: a necessidade de realização desses exames para elaboração do correto diagnóstico da recorrente, mesmo se inexistisse o defeito no laudo da tomografia. Em razão disso tais pedidos de reembolso foram rejeitados;

e) por fim, quando ao valor despendido para a realização da cirurgia de apendicite evidenciou-se que, mesmo se inexistente o defeito no laudo médico, tal cirurgia seria necessária, motivo pelo qual não existiu o nexo de causalidade entre o defeito apontado e este dano. Por conseguinte, também foi rejeitado este pedido.

\subsection{Excludentes da responsabilidade}

Descritos os elementos geradores da responsabilidade civil, passa-se a examinar algumas das circunstâncias que podem afastá-la.

No direito civil e processual civil brasileiro o ônus da prova normalmente pertence ao autor ${ }^{15}$. Assim, se este não comprovar todos os requisitos da responsabilidade civil, mesmo que o réu não se defenda adequadamente, a ação será julgada improcedente.

\footnotetext{
${ }^{15}$ Art. 333 do CPC: "O ônus da prova incumbe: I - ao autor, quanto ao fato constitutivo do seu direito; II ao réu, quanto à existência de fato impeditivo, modificativo ou extintivo do direito do autor. [...]"
} 
Por outro lado, se o autor fizer esta demonstração (ao menos aparentemente), caberá ao réu produzir a prova em sentido contrário, a fim de convencer o julgador da ausência do dever de indenizar.

No caso da responsabilidade subjetiva ou contratual, o profissional pode se eximir do dever de indenizar quando demonstrar a inexistência do dano, o cumprimento do contrato, ausência de culpa ou exclusão do nexo de causalidade. Existem duas hipóteses particulares: se a obrigação for de meio, o réu deverá comprovar que o ato foi realizado dentro das regras técnicas da profissão médica (ou seja, que não houve negligência, imprudência ou imperícia); se a obrigação for de resultado, deverá demonstrar que a intervenção atingiu o objetivo esperado (ou seja, que o contrato foi devidamente cumprido e que não houve dano).

Nos casos em que houver responsabilidade extracontratual, deverá o profissional comprovar a inexistência do dano, exclusão do nexo causal ou ainda ausência de culpa, esta também nas modalidades negligência, imprudência ou imperícia.

No tocante à responsabilidade objetiva, que prescinde da demonstração de culpa, os fornecedores de serviços (hospitais, clínicas, laboratórios, etc.) somente se desobrigam do dever de indenizar caso demonstrem a inexistência do dano, ausência de defeito no serviço ou exclusão do nexo de causalidade.

Existem diversos fatores excludentes do nexo causal, os quais valem para todos os tipos de responsabilidade mencionados e por isso serão estudados com maior detalhe:

- fato exclusivo da vítima;

- fato concorrente da vítima;

- fato de terceiro;

- caso fortuito e força maior.

O fato exclusivo da vítima, que também pode ser chamado de culpa exclusiva da vítima, ocorre quando esta, por meio de determinado comportamento, provoca de forma exclusiva o dano.

Aponta Panasco ${ }^{16}$ que:

O fato exclusivo da vítima concretiza-se, tratando-se de relação médicopaciente, por um comportamento inadequado por parte do paciente, de tal forma que exclui qualquer responsabilidade do médico, porque a conduta

\footnotetext{
${ }^{16}$ PANASCO, W. L., A responsabilidade civil, penal e ética dos médicos, $2^{\mathrm{a}}$ ed., Rio de Janeiro, 1984. p. 68.
} 
adotada pelo paciente rompe o nexo causal. (apud ROCHA, 2005, p. $388)$.

Cita-se como exemplo o paciente que não segue o tratamento recomendado por seu médico, ou ainda aquele que sai da cama do hospital contra a ordem médica e acaba sofrendo fraturas.

No fato concorrente da vítima, existe uma conduta inadequada tanto do médico como do paciente, mediante atos independentes. A solução que se adota é repartir os danos de acordo com a parcela de responsabilidade de cada um no evento danoso. A culpa concorrente da vítima não exclui a responsabilidade, porém leva a uma redução do quantum indenizatório. Tal hipótese encontra-se prevista no artigo 945 do Código Civi1 ${ }^{17}$.

Outra das possibilidades de ruptura do nexo causal é o fato de terceiro. Terceiro, como o nome sugere, é aquele que não possui qualquer vínculo com o suposto causador do dano ou com a vítima. Não se incluem nesta categoria os subordinados ou auxiliares do médico, que devem trabalhar sob supervisão constante deste (sob pena de culpa in eligendo ou in vigilando).

Para que se reconheça a excludente do fato de terceiro, é importante observar que o dano deve ser causado exclusivamente pelo terceiro. Se para o dano tiverem concorrido a vítima ou o médico, aplicam-se as regras relativas a eles.

Couto Filho e Souza (2008, p. 15) fornecem um exemplo: um paciente está internado e inconsciente, sob rigorosos cuidados médicos. Sua esposa decide, não obstante tal quadro clínico, retirá-lo do hospital e levá-lo para casa, alegando que pode pagar uma enfermeira particular e até a visita periódica de um médico, se for o caso, e que não o deixará internado nem mais um segundo, pois se tiver de vê-lo morrer, prefere que seja no seu lar. Após ouvir toda a orientação médica sobre os riscos de sua decisão, a esposa insiste e se compromete a assinar um termo de responsabilidade, afirmando que ninguém pode obrigar seu marido a ficar no hospital e, já que ele se encontra inconsciente, ela é sua responsável legal. Realizados todos os procedimentos de saída, o paciente vem a falecer durante o percurso para casa. Evidentemente, o médico não incorrerá em responsabilidade alguma pela morte dessa pessoa.

As últimas duas excludentes abordadas são os denominados caso fortuito e força maior. Na maior parte das legislações, estes termos são colocados juntos em seus textos, 
entretanto existe corrente doutrinária (Couto Filho, Souza e Rocha) que considera o caso fortuito como sendo aquele que se mostra imprevisível e inevitável, enquanto a força maior pode ser previsível, porém ainda assim é inevitável, como por exemplo os fenômenos da natureza.

A exclusão da responsabilidade nas hipóteses de caso fortuito e de força maior encontra-se expressamente prevista no artigo 393 do Código Civil ${ }^{18}$.

Destaca-se que o Código de Defesa do Consumidor, em seus artigos 12 , § $3^{\circ}$ e 14 , § $2^{\circ}$, traz como únicas hipóteses de não responsabilização a inexistência do defeito, a culpa exclusiva do consumidor ou de terceiro. Existe divergência na doutrina e na jurisprudência sobre se as excludentes do caso fortuito e da força maior seriam ou não aplicáveis aos fornecedores de produtos e serviços.

Melo (2008, p. 56-58) realizou um estudo detalhado sobre a matéria, colacionando entendimentos de Roberto Senise Lisboa e Luiz Antônio Rizzato Nunes no sentido de que o rol do Código de Defesa do Consumidor seria exclusivo, não admitindo nenhuma outra excludente que não as expressamente elencadas. De outro lado, Antonio Herman de Vasconcelos Benjamin, Jaime Marins e João Batista de Almeida defendem que a força maior e o caso fortuito devem ser aceitos nos casos que envolvam relações de consumo, posto não haver dúvidas de que quebram a relação de causalidade entre o defeito do produto e o dano causado ao consumidor, indispensável para que haja responsabilização civil.

A jurisprudência do Superior Tribunal de Justiça pacificou esta matéria com relação aos serviços, admitindo as excludentes do caso fortuito e força maior no sistema do Código do Consumidor a partir do voto do Ministro Eduardo Ribeiro no Recurso Especial $\mathrm{n}^{\mathrm{o}}$ 120.647/SP, $3^{\text {a }}$ Turma, julgado em 15.05.2000.

\footnotetext{
${ }^{17}$ Art. 945 do CC: "Se a vítima tiver concorrido culposamente para o evento danoso, a sua indenização será fixada tendo-se em conta a gravidade de sua culpa em confronto com a do autor do dano."

${ }^{18}$ Art. 393 do CC: "O devedor não responde pelos prejuízos resultantes de caso fortuito ou força maior, se expressamente não se houver por eles responsabilizado. Parágrafo único. O caso fortuito ou de força maior verifica-se no fato necessário, cujos efeitos não era possível evitar ou impedir."
} 


\subsection{A importância da prova na apuração dos fatos}

Nas ações civis, da mesma forma que nas demais esferas de responsabilidade, percebe-se uma grande dificuldade em determinar, com serenidade e exatidão, se o médico foi realmente negligente, imprudente ou imperito, ou se o dano decorreu de circunstâncias outras.

Muitas vezes os advogados dos autores descrevem de forma exagerada os danos sofridos e as evidências de má conduta médica, enquanto os defensores da parte contrária, fundamentados em obras científicas e pareceres de especialistas, alegam que seus clientes nunca se afastaram dos procedimentos corretos.

Sobre o ônus da prova, Theodoro Junior ${ }^{19}$ aponta:

A culpa do médico, pela natureza do contrato que firma com o cliente, somente será configurada quando os seus serviços tiverem sido prestados fora dos padrões técnicos. Por isso, o fato constitutivo do direito de quem pede indenização por erro médico se assenta no desvio de conduta técnica cometido pelo prestador de serviços. Como esse desvio é uma situação anormal dentro do relacionamento contratual não há como presumi-lo. Cumprirá ao autor da ação prová-lo adequadamente (CPC, artigo 333, I).

$\mathrm{Na}$ verdade, o serviço técnico do médico, com zelo e adequação, vem a ser a própria prestação contratual. Logo, quando o paciente se diz vítima de erro médico, na verdade está apontando o inadimplemento da prestação devida. Provar a culpa do médico, então, não é demonstrar apenas o elemento psicológico ou subjetivo da responsabilidade civil. É provar o inadimplemento mesmo da prestação devida pelo médico. E em qualquer ação de indenização por responsabilidade contratual, cabe sempre ao autor o ônus de provar o inadimplemento do réu. $\mathrm{O}$ que se dispensa, nos contratos de resultado, é a prova da culpa, nunca a do inadimplemento e a do dano.

A conduta irregular do médico é a um só tempo o inadimplemento e a culpa, razão pela qual o autor não se desobriga do ônus processual da prova senão comprovando a conduta culposa do médico. Sem a configuração desse tipo de conduta, jamais se admitirá como não cumprido o contrato de serviços médicos, salvo, é claro, nas hipóteses excepcionais de contratos médicos de resultado, a que já se aludiu, quando bastará ao paciente provar o dano e o nexo causal.

19 THEODORO JÚNIOR, Humberto. Aspectos processuais da ação de responsabilidade por erro médico. Revista de Processo, n. 95. 05 dez. 2005. São Paulo: Editora Revista dos Tribunais, 1999. 
Quando existe prova segura de procedimento irregular, como por exemplo uma radiografia que acusa um material cirúrgico esquecido no corpo do paciente, as evidências são claras, pouco havendo para discutir. O problema surge quando não há este tipo de elemento nos autos.

A prova do erro médico muitas vezes é quase impossível para o paciente supostamente lesado, principalmente em razão da dificuldade que este de obter documentos e testemunhas.

Existe uma complexidade técnica nos procedimentos que é quase inteiramente desconhecida aos leigos. Tais procedimentos são muitas vezes realizados por uma equipe, dentro de um estabelecimento de saúde, sendo que quando ocorre algum erro os membros desta equipe tendem a ficar em silêncio ou procuram justificar suas ações. Acrescente-se a tudo isto o tempo que por vezes ocorre entre o evento danoso e a propositura da ação, o que dificulta ainda mais a colheita e realização de provas.

A medicina não pode ser considerada uma ciência inteiramente exata. De fato, as atitudes dos médicos e seus auxiliares muitas vezes baseiam-se em probabilidades, em decisões tomadas sob forte pressão e até mesmo cansaço físico e psicológico.

Não se pode presumir que, no exercício normal de sua profissão, o médico pretenda causar algum dano ao paciente. E, mesmo que tenha errado, é raro que ele admita tal fato em um processo judicial ou administrativo.

A lei admite a produção de diversas espécies de prova para a apuração da conduta médica. Os meios de prova são todos os instrumentos que podem ser trazidos ao processo para ajudar o juiz a estabelecer a verdade dos fatos.

Os principais tipos de provas previstos no Código de Processo Civil são:

- depoimento pessoal;

- confissão;

- prova documental;

- prova testemunhal;

- prova pericial;

- inspeção judicial. 
Além disso, a lei processual permite o uso de quaisquer outros meios, desde que moralmente legítimos ${ }^{20}$.

O depoimento pessoal consiste na tomada de declarações em audiência de qualquer das partes do processo e pode ser determinado pelo juiz de ofício ou a pedido da parte contrária (art. 342 do CPC). As perguntas são feitas somente pelo juiz e pelo advogado da parte contrária. O advogado da própria parte não pode requerer o depoimento de seu cliente, uma vez que sua versão já se encontra nas peças apresentadas.

A confissão ocorre quando a parte admite a verdade de um fato, contrário ao seu interesse e favorável ao adversário (art. 348 do CPC). Pode ser judicial ou extrajudicial, espontânea ou provocada. A confissão espontânea é feita mediante termo nos autos e a provocada consta do depoimento pessoal prestado pela parte.

A prova documental normalmente é trazida pela parte interessada quando se manifesta no processo. Se acaso o documento estiver em poder da parte contrária, o juiz pode conceder um prazo para que esta o apresente ou justifique a recusa, sob pena de serem admitidos como verdadeiros os fatos que o solicitante do documento pretendia comprovar (artigos 355 a 363 do CPC).

Um dos documentos mais importantes dentro dos processos judiciais e administrativos é o prontuário médico. O mesmo é definido na Resolução no 1.638/2002 do Conselho Federal de Medicina como sendo:

O documento único constituído de um conjunto de informações, sinais e imagens registradas, geradas a partir de fatos, acontecimentos e situações sobre a saúde do paciente e a assistência a ele prestada, de caráter legal, sigiloso e científico, que possibilita a comunicação entre membros da equipe multiprofissional e a continuidade da assistência prestada ao indivíduo.

A mesma resolução, em seu artigo $5^{\circ}$, dispõe quais são os itens que devem constar obrigatoriamente do prontuário confeccionado em qualquer suporte, eletrônico ou papel:

a) Identificação do paciente - nome completo, data de nascimento (dia, mês e ano com quatro dígitos), sexo, nome da mãe, naturalidade (indicando o município e o estado de nascimento), endereço completo

20 Art. 332 do CPC: "Todos os meios legais, bem como os moralmente legítimos, ainda que não especificados neste Código, são hábeis para provar a verdade dos fatos, em que se funda a ação ou a defesa." 
(nome da via pública, número, complemento, bairro/distrito, município, estado e CEP);

b) Anamnese, exame físico, exames complementares solicitados e seus respectivos resultados, hipóteses diagnósticas, diagnóstico definitivo e tratamento efetuado;

c) Evolução diária do paciente, com data e hora, discriminação de todos os procedimentos aos quais o mesmo foi submetido e identificação dos profissionais que os realizaram, assinados eletronicamente quando elaborados e/ou armazenados em meio eletrônico;

d) Nos prontuários em suporte de papel é obrigatória a legibilidade da letra do profissional que atendeu o paciente, bem como a identificação dos profissionais prestadores do atendimento. São também obrigatórias a assinatura e o respectivo número do CRM;

e) Nos casos emergenciais, nos quais seja impossível a colheita de história clínica do paciente, deverá constar relato médico completo de todos os procedimentos realizados e que tenham possibilitado o diagnóstico e/ou a remoção para outra unidade.

O prazo mínimo recomendado para armazenagem do prontuário médico é de dez anos, correspondente ao prazo prescricional das ações pessoais previsto no Código Civil.

A prova testemunhal consiste na oitiva de pessoas pelo juiz em audiência. São feitas perguntas à testemunha pelo juiz, em seguida pelo advogado da parte que arrolou a testemunha e por fim pelo patrono da parte contrária. Quando a matéria for incontroversa, já estiver comprovada por documentos ou somente puder ser comprovada por exame pericial, o juiz pode dispensar ou indeferir a inquirição de testemunhas.

A inspeção judicial consiste na possibilidade do juiz de ir até determinado local para inspecionar pessoas ou coisas, a fim de esclarecer sobre fato que interesse à decisão da causa (artigo 440 do CPC). É realizada de ofício ou a pedido das partes, sendo que o juiz pode se fazer acompanhar de um ou mais peritos. As partes sempre têm o direito de acompanhar a inspeção, devendo ser lavrado auto circunstanciado de tudo que for útil ao julgamento.

A última espécie de prova descrita no Código de Processo Civil, que consiste no cerne deste trabalho e será analisada com maiores detalhes no próximo item, é a pericial. Dificilmente se encontrará um processo por erro médico sem que seja determinada a realização de perícia, uma vez que a apuração da ocorrência ou não de tal erro depende de conhecimentos técnicos específicos que o juiz não possui.

Veja-se o que diz Theodoro Junior (op cit): 
Nem sempre é possível um juízo rigoroso, preciso, sobre a falha técnica e seu nexo com a lesão ou dano. Os tribunais, por isso, adotam, às vezes, princípios antigos e universalmente aceitos como o da previsibilidade e o da razoabilidade. O julgador segue sua experiência da vida, e da observação do que comumente acontece pode chegar a juízos de valor sobre a conduta profissional, quando se mostre muito difícil uma conclusão puramente técnica sobre a causa da lesão.

O ideal, porém, é exigir o magistrado, sempre, a prova pericial, para obter esclarecimentos que, de ordinário, não se comportam na esfera de seus conhecimentos e que se sujeitam a regras técnicas específicas e complexas.

Isto não quer dizer que o juiz fique escravo do laudo pericial. O CPC é claro ao estatuir que "o juiz não está adstrito ao laudo pericial, podendo formar a sua convicção com outros elementos ou fatos provados nos autos" (artigo 436).

\subsection{A prova pericial}

Torna-se essencial para o prosseguimento deste trabalho e análise dos dados colhidos um estudo da prova pericial em espécie, seus elementos e os participantes envolvidos na elaboração da mesma.

Nos dizeres de Moraes (2003, p. 594):

A expressão perícia vem do latim e indica habilidade. É utilizada no sentido amplo para a diligência feita para esclarecer fatos. Significa pesquisa, exame, a verificação de fatos e deve ser feita por pessoa de reconhecida competência técnica no assunto.

O renomado processualista Dinamarco (2004, p. 585) também traz sua definição: "Perícia é o exame feito em pessoas ou coisas, por profissional portador de conhecimentos técnicos e com a finalidade de obter informações capazes de esclarecer dúvidas quanto a fatos".

O artigo 145, caput, do Código de Processo Civil dispõe: "Quando a prova do fato depender de conhecimento técnico ou científico, o juiz será assistido por perito, segundo o disposto no artigo 421". 
É até possível que o juiz tenha o conhecimento técnico ou científico para esclarecer os pontos controvertidos no julgamento de determinada questão. Entretanto, entende-se que a ocorrência de tal situação não deve afastar a realização da perícia, uma vez que este tipo de prova serve também para dirimir eventuais dúvidas que o juiz possa ter, convencer as partes a respeito da decisão que será tomada e auxiliar os Tribunais superiores, que eventualmente poderão julgar recursos.

O artigo 420 do Código de Processo Civil menciona três tipos de perícia: exame, vistoria e avaliação. Nas palavras de João Batista Lopes (2002, p. 131) exame "é a espécie de perícia que recai sobre coisas ou pessoas com a finalidade de verificação de fatos ou circunstâncias de interesse da causa".

A vistoria é uma inspeção realizada em bens imóveis e a avaliação é a fixação ou estimação do valor de mercado de coisas móveis ou imóveis. Ambas, por possuírem finalidades especificas, não serão abordadas neste trabalho.

Já o parágrafo único do referido artigo 420 traz algumas hipóteses em que o juiz pode negar a realização da perícia:

a) quando a prova do fato não depender do conhecimento especial de técnico;

b) quando for desnecessária em vista de outras provas produzidas;

c) quando a verificação for impraticável.

$\mathrm{Na}$ opinião de Lopes, sempre que o juiz puder, de forma mais simples ou menos onerosa, apurar a veracidade das alegações das partes, deverá evitar a realização da prova pericial e valer-se de outros elementos para formar sua convicção.

$\mathrm{Na}$ prática, porém, verifica-se que isso raramente ocorre. As questões postas em juízo pelas partes são tão complexas e suas versões dos fatos tão divergentes que a prova pericial se torna indispensável, vindo a se somar com as demais.

Prossegue-se com as definições de perito. Para Wambier, Almeida e Talamini (2006, p. 443), o perito "é um especialista em determinado ramo do saber, técnico ou científico, convocado como auxiliar da justiça para atuar no processo onde este meio de prova é admissível".

O professor França (2008, p. 17) elucida: "Entendem-se por peritos pessoas qualificadas ou experientes em certos assuntos a quem incumbe a tarefa de esclarecer um fato de interesse da Justiça, quando solicitadas". 
Em alguns casos, não se exige que o perito seja letrado ou tenha curso superior, mas que tenha conhecimento sobre a área em questão. Por exemplo, um mecânico pode servir como perito em caso de danos causados a veículo.

Em outros, entretanto, é necessária e praticamente obrigatória especial qualificação. Tratando-se de perícia de natureza médica, doença física ou mental, é essencial que o perito também seja médico.

O perito é alguém de confiança do juiz e pode ser nomeado livremente. Por ser considerado auxiliar da justiça, assume responsabilidades perante o juízo, não podendo apresentar qualquer dos motivos de suspeição ou impedimento com as partes, por exemplo vínculo de amizade íntima, inimizade capital, relação comercial, parentesco até segundo grau, interesse na causa, etc. (arts. 134 e 135 do CPC).

Assistentes técnicos são profissionais nomeados pelas partes que podem acompanhar os trabalhos do perito e eventualmente realizarem seus próprios pareceres, criticando ou apoiando as conclusões do perito oficial. Por serem de confiança das partes e contratados por estas, não estão sujeitos a impedimento ou suspeição (art. 422 do CPC).

Por terem a mesma formação profissional e muitas vezes a mesma especialização dos investigados, isto leva a uma importante discussão a respeito da possibilidade de corporativismo dos profisssionais da medicina na realização das perícias.

Kfoury Neto (2002, p. 69), preocupando-se com o assunto, discorre:

Evidentemente, há natural tendência dos médicos ao exame mais tolerante do ato culposo, atribuído a colega seu. Tal afirmativa não encerra nenhum intuito de reprovação genérica ou acusação infundada. Apenas se quer dizer que o médico, ele próprio convicto de que deseja somente o melhor para o enfermo sob seu cuidado, busca automaticamente explicação científica (ou fática) para o erro do demandado. Custa-lhe admitir que o colega foi imperito, imprudente ou negligente. Prefere-se, por isso mesmo, utilizar expressões como "intercorrência", "acidente", "complicação", "fatalidade" ou "mau resultado".

Mas os médicos - como já dissemos - erram. E, quando esse desvio chega ao Judiciário, é preciso que um perito, também médico, preferencialmente atuando na especialidade considerada, identifique com clareza o erro.

Aí surgem as dificuldades mencionadas linhas atrás. Laudos inconclusivos, dúbios, tergiversantes, contendo meias-verdades, reveladores do receio de "condenar o colega". 
Melo (2008, p. 172) concorda com tais assertivas, acrescentando:

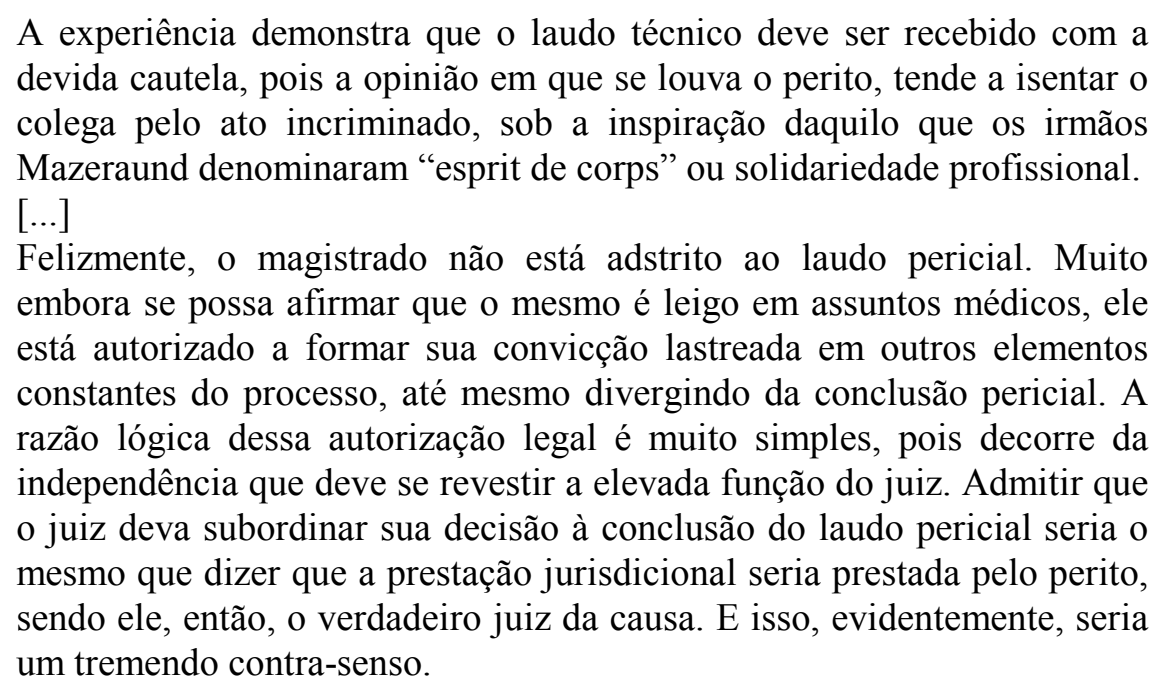

Para Moraes (2003, p. 459), o espírito de corpo pode até existir, porém jamais para acobertar os médicos negligentes, imprudentes e imperitos, e sim para fortalecer o médico idôneo, competente, dedicado, assim como sua classe.

Entende-se que deve ser aplicado o brocardo latino iudex est peritum peritorum, vale dizer: "o juiz é o perito dos peritos". Cabe ao julgador, com base em sua experiência profissional e de vida, analisar todos os elementos dos autos, e não somente a perícia, para chegar a uma decisão verdadeiramente justa.

\subsection{Procedimentos da perícia e elementos do laudo}

Os procedimentos necessários para a determinação e realização da perícia estão disciplinados pelo Código de Processo Civil.

Normalmente na petição inicial e na contestação as partes se limitam a protestar genericamente pela produção de todas as provas em direito admitidas. Somente no saneamento do processo, após a fixação dos elementos controvertidos, é que o juiz define ou não a necessidade da perícia (artigo 331, § $2^{\circ}$ do CPC).

Deferida a prova pericial, o juiz nomeia o perito, fixa o prazo para a entrega do laudo e possibilita às partes formular quesitos e indicar assistentes técnicos (art. 421 do CPC). 
Os quesitos são indagações que o juiz e as partes formulam para serem respondidas pelo perito e, eventualmente, pelos assistentes técnicos. Leciona Dinamarco sobre os quesitos (2004, p. 593-594):

Eles devem guardar pertinência com a causa e com os pontos a provar, fixados pelo juiz na audiência preliminar (art. 331, § $2^{\circ}$ ). Não são admissíveis quesitos que transcendam a matéria de fato sujeita à perícia, como os que indagam sobre fatos incontroversos ou a serem provados por testemunhas mediante documentos; o juiz deve indeferir tais quesitos por impertinência (art. 426, inc. I). Também não é lícito pedir conclusões jurídicas ao perito, ao qual incumbe apenas, como auxiliar da Justiça, informar o juiz sobre matéria de fato, para que este conclua; eventual resposta a quesitos desta ordem é inócua e não deve ser considerada pelo julgador, que é titular executivo do poder de decidir.

As despesas com a perícia cabem à parte que a requereu, ou então ao autor, quando requerida por ambas as partes. Em casos de assistência judiciária gratuita, no estado de São Paulo a perícia normalmente é realizada pelo IMESC ou então por perito de confiança do juízo que aceite fazê-la gratuitamente ou concorde em receber sua remuneração pelo vencido, ao final da causa.

Em seus trabalhos, o perito deverá realizar exames, análises de documentos, investigações, pesquisas e diligências, apresentando ao final em juízo um documento escrito chamado laudo pericial.

Moraes (2003, p. 595) dá uma boa definição da palavra laudo:

Laudo é a expressão latina empregada genericamente para denominar o documento escrito exarando parecer ou relatório dos peritos. Pode limitar-se a fornecer uma informação, ser conclusivo ou ser um esclarecimento de ordem técnica, dependendo da natureza da perícia. Desse fato decorre a expressão laudo pericial.

Como visto, o juiz não está obrigado a seguir as conclusões do laudo, porém deverá indicar na sentença os motivos de seu convencimento (art. 131 e 436 do CPC) ${ }^{21}$. O afastamento das conclusões do laudo deve estar apoiado em fundamentos consistentes, notadamente em outros elementos probatórios existentes no processo.

\footnotetext{
${ }^{21}$ Art. 131 do CPC: "O juiz apreciará livremente a prova, atendendo aos fatos e circunstâncias constantes dos autos, ainda que não alegados pelas partes; mas deverá indicar, na sentença, os motivos que lhe formaram o convencimento."

Art. 436 do CPC: "O juiz não está adstrito ao laudo pericial, podendo formar a sua convicção com outros elementos ou fatos provados nos autos.”
} 
Para fins de organizar o estudo das questões discutidas, clareza de exposição e justificativa de suas conclusões, os laudos periciais apresentados nos processos judiciais devem conter determinados elementos. A ausência ou omissão destes elementos dificulta o trabalho do juiz e das partes, podendo ainda demonstrar falta de diligência do perito.

Alcântara (2006, p. 15) leciona que em todos os laudos devem constar as seguintes partes:

a) Preâmbulo (preambulus) é a introdução, que se refere ao local da perícia, à data e hora, à autoridade solicitante, aos peritos designados, à identificação da pessoa ou do objeto a ser periciado, ao exame a ser realizado e aos quesitos a serem respondidos.

b) Histórico ou comemorativo, que é um relato completo do fato, justificador do pedido da perícia.

c) Descrição (visum er repertum), que encerra, com todos os detalhes, os achados objetivos e subjetivos dos exames realizados.

d) Discussão, que é o debate, a confrontação de hipóteses, as possíveis controvérsias de cada caso.

e) Conclusão, que é a ilação tirada com a análise dos dados descritos e discutidos, a posição final procurada pelo solicitante da perícia.

f) Respostas aos quesitos, que permitem a formação de juízos.

O professor Moraes (2003, p. 595-596) fornece algumas definições diferentes:

a) Cabeçalho - nome completo do profissional, sua qualificação técnica, quem nomeou ou solicitou a perícia e seu objetivo.

b) Identificação do indivíduo, corpo ou objeto - descrição do indivíduo com indicação dos documentos que permitem sua identificação e, se for o caso, do corpo ou de objeto em exame.

c) Histórico - resumo dos acontecimentos, indicando com clareza e destacando a data de cada ocorrência e as conseqüentes alterações causadas.

d) Exame físico - completo e minucioso do ser humano vivo ou morto, juntando os exames complementares pedidos ou apresentados. Incluemse aqui todos os exames necessários para o diagnóstico preciso.

e) Discussão - nela, o perito pode confrontar os dados observados com os da literatura e interpretar ou mesmo elaborar conjecturas especulativas que permitam a interpretação do fato ou do fenômeno. 
f) Conclusões - aqui o perito deve expor, de maneira articulada, os resultados finais do parecer.

g) Respostas aos quesitos - aqui se espera concisão e objetividade, devendo o perito responder laconicamente cada item. Os laudos de corpo de delito indagam de forma sistemática os quesitos da lei.

Tais autores observam que o laudo, embora seja opinativo, não pode ter conclusões jurídicas, pois estas cabem ao juiz. Não cabe ao perito, por exemplo, dizer se a ação deve ser julgada procedente ou não. Mas as respostas e análises feitas devem ser objetivas e tocar diretamente os pontos indagados, procurando identificar com clareza se o médico ou profissional de saúde cometeu ou não erro, quais os danos físicos observados, se os danos decorreram da conduta do médico, etc.. Também é aconselhável que o perito preste outras informações pertinentes que tiver, ainda que fora do âmbito estrito dos quesitos, mas sempre com relação à causa e dentro dos limites de sua função auxiliar.

Após a entrega do laudo, as partes devem se manifestar sobre o mesmo e, caso queiram, juntar os pareceres de seus assistentes técnicos.

As partes podem fazer críticas ao laudo oficial ou concordar com o mesmo. Quesitos suplementares somente são admitidos durante as diligências e antes da entrega do laudo (art. 425 do CPC), porém excepcionalmente se admitem pedidos de esclarecimentos, desde que corretamente fundamentados.

Quando, após a entrega do laudo oficial, o juiz não se sentir suficientemente seguro para decidir e entender que as questões não foram suficientemente esclarecidas, a lei lhe dá a faculdade de determinar uma nova perícia ${ }^{22}$.

${ }^{22}$ Art. 437 do CPC: "O juiz poderá determinar, de oficio ou a requerimento da parte, a realização de nova perícia, quando a matéria não lhe parecer suficientemente esclarecida." 


\section{MÉTODO}

\subsection{Casuística}

Quarenta e seis processos judiciais de responsabilidade civil nos quais os autores alegaram a ocorrência de erro médico.

\subsection{Fontes dos processos}

Os processos foram obtidos junto ao Departamento Jurídico de Defesa Profissional da Associação Paulista de Medicina, entidade federada da Associação Médica Brasileira, localizada na cidade de São Paulo, preservando-se os nomes das partes por questão de respeito e sigilo.

Foram examinados todos os processos em curso naquele departamento, iniciados a partir do ano de 1997, com laudos periciais já realizados e relatados.

\subsection{Dados coletados dos processos}

A coleta de dados foi realizada mediante pesquisa documental, extraindo-se fotocópias das principais peças dos processos, a saber: petições iniciais feitas pelos autores, contestações oferecidas pelos réus, quesitos formulados aos peritos para resposta, laudos entregues, eventuais pedidos de esclarecimentos, laudos complementares e, quando existentes, as sentenças de primeiro grau e acórdãos proferidos em grau de apelação.

Todos os dados foram colhidos no período de junho de 2008 a março de 2009, obtendo-se os quarenta e seis processos mencionados acima. 
Realizou-se um resumo das peças de cada processo, com o propósito de auxiliar no levantamento das questões mais importantes. O estudo foi orientado pelas seguintes técnicas de análise:

- Análise descritiva. As informações constantes de cada processo foram submetidas à tabulação a fim de caracterizar o conjunto analisado e verificar se os laudos continham todos os elementos recomendados e descritos na parte teórica. Os dados colhidos nesta parte foram:
a) número do processo;
b) cidade em que tramita o processo;
c) se os autores fizeram pedido de justiça gratuita;
d) quais os problemas alegados pelos autores;
e) se o laudo foi realizado por perito do juízo ou do IMESC;
f) número de páginas do laudo;
g) se o laudo continha introdução e histórico do caso;
h) se o perito realizou exame físico geral e especial no periciando;
i) se o laudo apresentou análise dos documentos dos autos judiciais;
j) se os laudo continha discussão fundamentada;
k) se o laudo apresentou conclusão clara;
1) se o laudo respondeu todos os quesitos das partes;
m) se houve pedido de esclarecimentos ou de laudo complementar.

- Análise crítica. Em complemento à análise descritiva, buscou-se um exame sistemático e qualitativo dos processos e dos laudos periciais. Foram examinados os seguintes pontos, a fim de ponderar se os laudos cumpriram adequadamente sua função de auxiliar na decisão do juiz:

a) aspectos relevantes dos processos;

b) quais os tipos de dano mais freqüentemente alegados pelos autores;

c) quais os pedidos de indenização mais comuns, dentro da seguinte classificação: danos físicos, danos morais, danos estéticos, devolução do valor pago, despesas médicohospitalares e/ou nova cirurgia, lucros cessantes e/ou pensão e outras despesas (específicas para cada caso);

d) tempo decorrido entre o ajuizamento da ação e a sentença de primeiro grau; 
e) se os laudos apresentaram todos os elementos recomendados;

f) como os peritos fundamentaram suas conclusões;

g) a importância de os peritos serem ou não especialistas para elaboração dos laudos e acolhimento pelo juízo;

h) quais os resultados das ações, ou seja, como foram julgadas até o momento em que foram colhidos os dados;

i) relevância dos laudos nas sentenças e acórdãos;

j) outras partes apresentadas pelos peritos nos laudos (por exemplo: fotografias, exposições teóricas, etc.);

k) observações e sugestões para elaboração dos laudos periciais.

Os principais dados sintetizados e dispostos no formato de tabela encontram-se disponíveis no apêndice deste trabalho. 


\section{RESULTADOS}

\subsection{Descrição geral dos processos}

No presente estudo foram examinados quarenta e seis processos judiciais de responsabilidade civil por alegado erro médico, com perícia realizada e laudo pericial juntado nos autos.

Todos os processos foram instaurados na justiça estadual de São Paulo. Na comarca de São Paulo (capital) tramitaram 31 processos $(67,4 \%)$ e nas demais comarcas tramitaram 15 feitos $(32,6 \%)$.

Gráfico 1 - Distribuição dos processos dentro do Estado

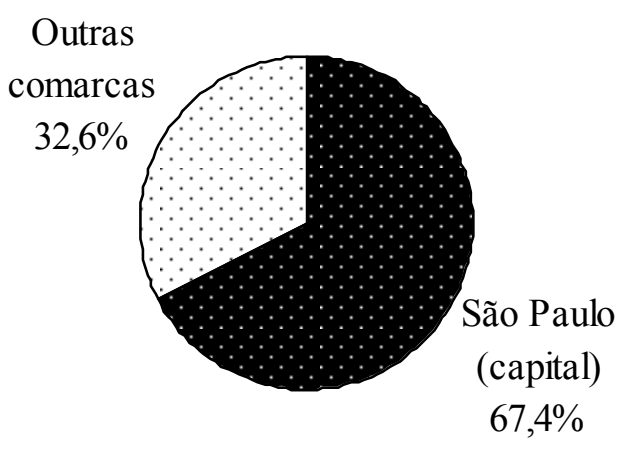

Em 38 processos $(82,6 \%)$ os autores pediram os benefícios da justiça gratuita e apenas $8(17,4 \%)$ ingressaram com a ação sem tal pedido. 


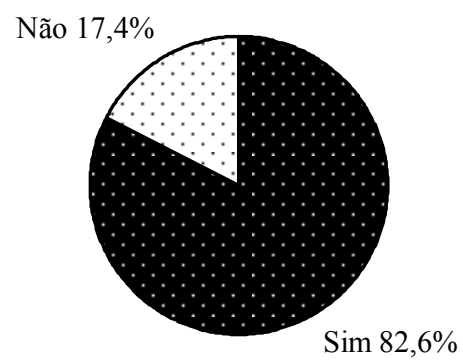

Buscou-se em seguida quais foram os problemas alegados pelos autores no conjunto analisado. Os casos de erro em cirurgia não-estética foram 25 (54,3\%), sendo que destes 4 foram relativos a objetos esquecidos em pacientes e outros 3 com resultado morte. Erros de diagnóstico e/ou falhas no atendimento em hospitais/pronto-socorros foram alegados em 7 casos $(15,2 \%)$, sendo 4 com resultado morte. Cirurgias estéticas com resultado diverso do esperado consistiram em 6 casos $(13,0 \%)$. Por fim, restaram 8 casos $(17,4 \%)$ que, por combinarem dois ou mais tipos de erro, por sua complexidade ou particularidade, foram classificados na categoria outros.

Gráfico 3 - Problemas alegados pelos autores

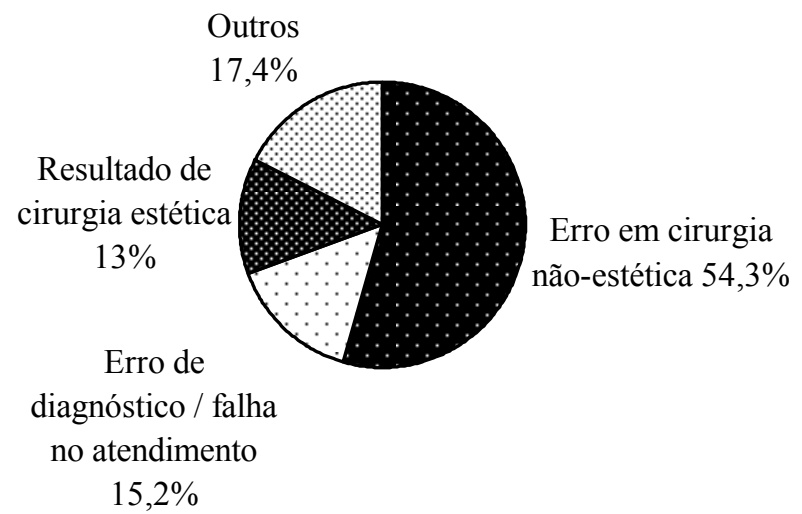




\title{
4.2 Descrição geral dos laudos periciais
}

Constatou-se que 27 laudos (58,7\%) foram realizados por peritos do IMESC, enquanto os 19 laudos restantes $(41,3 \%)$ foram elaborados por peritos médicos particulares indicados pelo juízo.

\author{
Gráfico 4 - Realização dos laudos
}

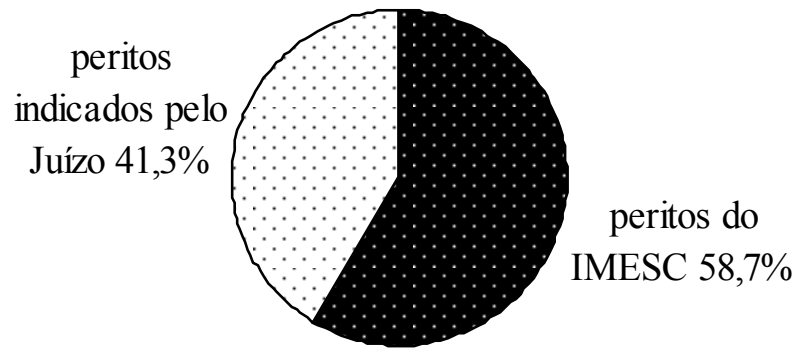

O número de páginas de cada laudo variou entre 1 e 110 . O menor laudo continha apenas as respostas aos quesitos, de forma bastante sucinta, enquanto o maior continha longa exposição teórica, sendo que algumas passagens não tinham qualquer relação com o tema do laudo. Excluindo-se tais laudos, a média ficou em 10,5 páginas por laudo, sendo que o valor mais freqüente foi de 4 páginas em oito dos laudos apresentados. 


\title{
4.3 Elementos específicos constantes dos laudos
}

Do conjunto examinado, 44 laudos $(95,7 \%)$ continham introdução e histórico do caso, enquanto $2(4,3 \%)$ não os possuíam.

\author{
Gráfico 5 - Laudos que apresentaram introdução/ \\ histórico do caso
}

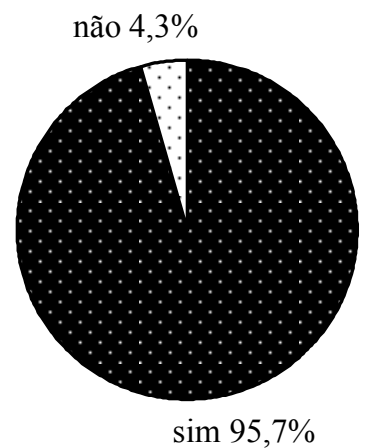

Outro componente do laudo é o exame físico geral e especial. Em 32 casos $(69,6 \%)$ foi realizado este exame, em $6(13,0 \%)$ não há qualquer menção e em $8(17,4 \%)$ o exame direto ficou prejudicado em razão da morte da parte periciada ( 7 pacientes morreram durante o ato médico e 1 morreu no decorrer da ação).

\section{Gráfico 6 - Laudos que apresentaram exame físico geral/especial}

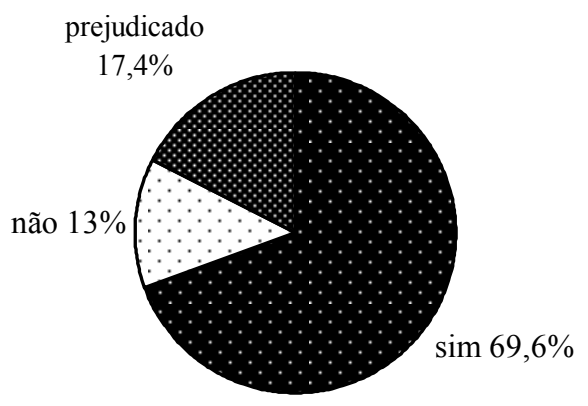


Em 41 laudos $(89,1 \%)$ o perito narrou ter examinado os documentos existentes no processo judicial, sendo que em 5 deles $(10,9 \%)$ nada foi mencionado.

\section{Gráfico 7 - Laudos que apres entaram exame dos documentos dos autos}

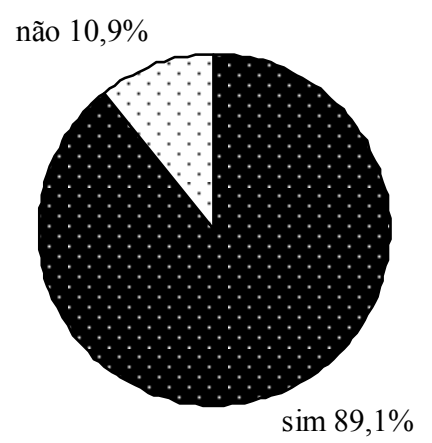

Embora seja uma das partes mais importantes do trabalho pericial, verificou-se que apenas 26 laudos (56,5\%) apresentaram uma discussão fundamentada. Outros 12 (26,1\%) continham uma fundamentação parcial e $8(17,4 \%)$ não tiveram nenhum tipo de discussão ou fundamentação.

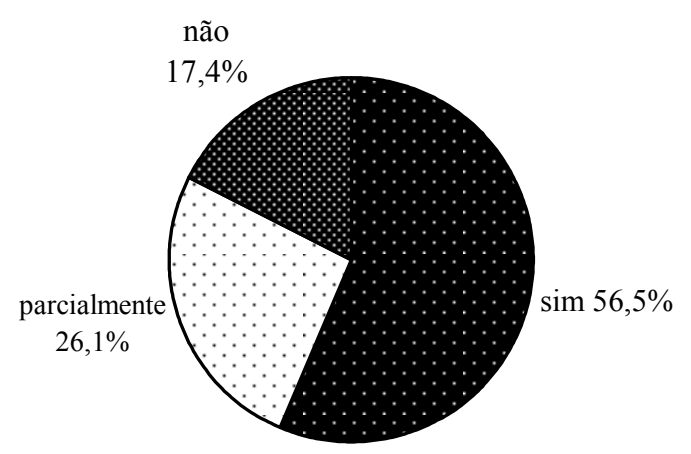


No conjunto analisado, um total de 29 laudos $(63,0 \%)$ continham uma conclusão clara, e 17 (37,0\%) não a apresentaram. Nestes últimos, foram incluídos tanto os laudos que não tinham conclusão, como aqueles que deixavam de emitir a opinião do perito, e ainda os que continham frases como "dizer se houve ou não erro é missão privativa do juiz".

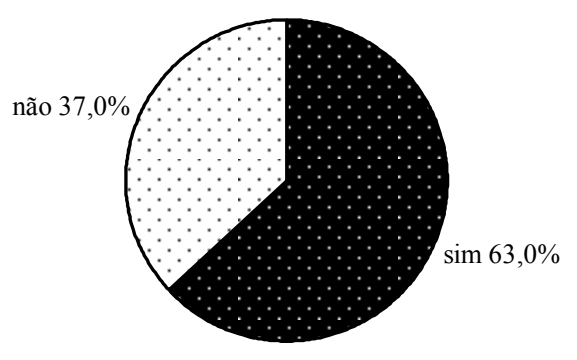

No conjunto estudado houve resposta integral a todos os quesitos das partes em 33 casos $(71,7 \%)$. Em 9 casos $(19,6 \%)$ o perito não respondeu nenhum quesito, em 3 casos $(6,5 \%)$ respondeu apenas os quesitos de uma das partes, deixando de responder os da outra parte e em 1 caso $(2,2 \%)$ as partes não apresentaram quesitos.

\section{Gráfico 10 - Laudos que responderam todos os quesitos formulados}

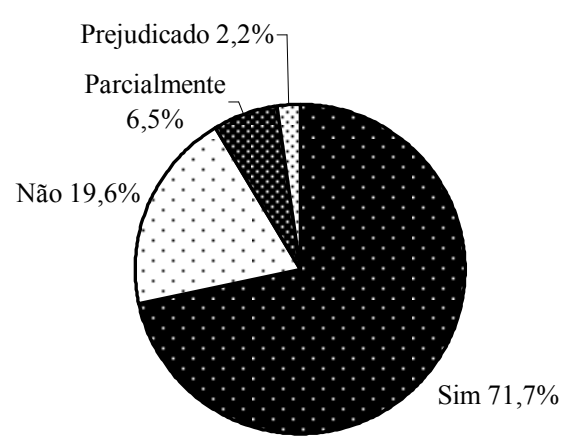


Além das respostas aos quesitos faltantes, houve 28 processos em que foram pedidos esclarecimentos ou a realização de laudo complementar (60,9\%). Em 18 casos $(39,1 \%)$ não foram solicitados esclarecimentos.

Gráfico 11 - Pedidos de esclarecimentos

ou laudo complementar

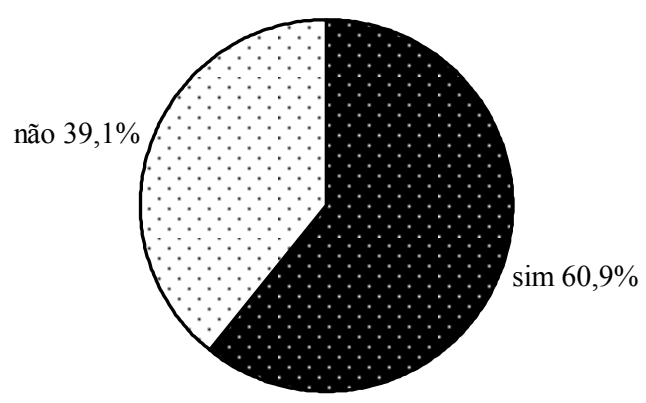




\section{DISCUSSÃO}

Durante a coleta de dados junto ao Departamento Jurídico de Defesa Profissional da Associação Paulista de Medicina foram examinados aproximadamente duzentos processos, porém muitos deles se encontravam na fase inicial ou aguardavam a vinda dos respectivos laudos, o que restringiu a obtenção de um número maior.

Dentre os que continham laudos, o processo mais antigo teve início em 1997 e o mais recente em 2007. Considerando que a obtenção dos dados terminou em março de 2009, verificou-se que dificilmente a realização do laudo ocorre em menos de dois anos.

Não foi possível aferir com exatidão o tempo gasto pelos peritos para elaboração e entrega dos laudos, em razão da falta de elementos suficientes em alguns deles, tais como: data de retirada dos autos ou recebimento das principais peças e quesitos pelo perito, data do exame físico das partes, ausência de data no corpo do laudo, divergências entre a data constante do laudo e a efetiva entrega em juízo e outros.

Usou-se então como critério aproximado o tempo decorrido desde a entrega dos quesitos pelas partes (obtido nas respectivas petições) até a juntada do laudo aos autos, constatando-se diferenças significativas entre o tempo despendido pelos peritos do juízo e os do IMESC.

Para os peritos particulares indicados pelo juízo, o tempo mínimo para entrega do laudo foi de 1 mês e meio e o máximo de 2 anos e 6 meses, sendo o médio de 11 meses. Quando a perícia foi realizada pelo IMESC, o tempo mínimo foi de 2 meses e o máximo de 3 anos e 2 meses, sendo o médio de 1 ano e 4 meses.

Como se pode observar, os peritos do IMESC demoraram mais para entregar seus laudos do que os peritos do juízo. A hipótese mais provável para esta diferença, conforme a prática judicial, é que estes últimos possuem interesse em terminar o trabalho rapidamente para receberem seus honorários, enquanto aqueles se encontram em órgão oficial com grande volume de trabalho. Para que não haja maiores atrasos na prestação jurisdicional, o Estado deveria dotar o IMESC de recursos humanos e materiais.

Nem sempre a rapidez na entrega do laudo é uma garantia de qualidade. Houve um laudo entregue em dois meses que continha apenas uma página e cujo conteúdo foi considerado inadequado e insuficiente. Alguns dos laudos que demoraram mais de dois anos para serem entregues não tinham fundamentação ou conclusão claras. 
Não se conseguiu encontrar um critério uniforme utilizado pelos peritos para avaliar se o médico atuou ou não com negligência, imprudência ou imperícia, ou mesmo para a determinação do nexo causal. Trata-se de dificuldade já relatada na exposição a respeito das provas (itens 2.10 e 2.11 acima).

Os elementos da responsabilidade civil passíveis de apuração com maior grau de certeza foram os danos físicos, estéticos e materiais e as situações de evidente inobservância de regras técnicas.

Outro problema encontrado foi que em muitos casos não houve como se saber a especialidade dos peritos que elaboraram os laudos. Nos 46 processos, apenas 20 peritos declararam ter a especialização necessária para o caso examinado, enquanto 26 não declinaram sua especialização. A incerteza a respeito da qualificação de mais da metade dos peritos criou dificuldades para analisar a relação entre a especialização destes e a aceitação dos laudos.

Com relação à pesquisa bibliográfica, não foram encontrados estudos que pudessem servir de comparação a este. Não obstante, verificaram-se dois estudos assemelhados, um na área de perícia contábil ${ }^{23}$ e outro na área de psiquiatria forense ${ }^{24}$, mas que tiveram limitada aplicação no presente.

\subsection{Comentários sobre os processos}

O primeiro item que chamou a atenção foi o número expressivo de pedidos de justiça gratuita. Conforme já apresentado no item 4.1, um percentual de 82,6\% dos autores pediu os benefícios da justiça gratuita.

Cumpre observar que quando a justiça gratuita é deferida, a parte não precisa pagar as custas iniciais da ação (1\% sobre o valor da causa no estado de São Paulo) e, caso saia vencida ao final, fica isenta de pagar os honorários advocatícios da parte contrária. Para concessão do benefício, a Lei Federal $n^{0} 1.060 / 50$ prevê que basta a parte afirmar na

23 SANTANA, Creusa Maria Santos de. A perícia contábil e sua contribuição na sentença judicial: um estudo exploratório. Dissertação de mestrado. Faculdade de Economia e Administração, Universidade de São Paulo, São Paulo, 1999. 
petição inicial que não está em condições de pagar as custas do processo e os honorários de advogado sem prejuízo de seu sustento e de sua família.

O que se tem observado na prática forense é que, em razão do texto legal, algumas pessoas pedem a justiça gratuita sem fazerem jus ao benefício, como forma de se livrarem dos encargos processuais em caso de improcedência.

Há casos de pessoas abastadas que contratam escritórios particulares de advocacia e ainda assim postulam a justiça gratuita. Outras pedem indenizações elevadíssimas e alegam não terem condições de pagarem as custas do processo.

Quando a parte não tem condições financeiras para contratar um advogado, deve se submeter à triagem da Defensoria Pública, a qual exige comprovação de baixa renda familiar. Em todos os 46 processos analisados neste estudo os autores tinham advogados constituídos, ou seja, existem indícios de que pagaram pelo trabalho destes e que também poderiam pagar pelas custas. Cumpre aos juízes uma fiscalização e maior rigor na concessão deste benefício da justiça gratuita, a fim de evitar o abuso e a má-fé de algumas partes.

Com um percentual tão elevado de autores beneficiários da justiça gratuita, seria de se esperar que a grande maioria das perícias fosse realizada pelo Instituto de Medicina Social e de Criminologia de São Paulo (IMESC), órgão público que realiza as perícias gratuitamente. Entretanto, o IMESC elaborou 58,7\% dos laudos periciais e os outros médicos indicados pelo juízo 41,3\%.

Para esclarecer esta situação, a análise dos documentos dos autos permitiu constatar que, nos casos de justiça gratuita, as perícias feitas por médicos do juízo foram pagas pelos réus, realizadas gratuitamente ou então sob a condição de serem pagas ao final pela parte vencida.

Embora sediado em São Paulo, capital, o IMESC não atuou somente em processos que corriam nesta cidade. Dos 31 processos da capital, os peritos do IMESC atuaram em 18 $(58,1 \%)$, enquanto em 13 foram nomeados peritos do juízo (41,9\%). Nos 15 processos de outras cidades, os peritos do IMESC atuaram em 9 (60\%) e os do juízo em 6 (40\%).

Outro dado que se destacou foram os tipos de dano alegados pelos autores: 54,3\% dos processos trataram de erros em cirurgia não estética, 15,2\% sobre erros de diagnóstico

${ }^{24}$ RAMOS, Maria Regina Rocha. Estudo da concordância entre laudos psiquiátricos conclusivos de capacidade parcial de imputação e sentenças judiciais. Dissertação de mestrado. Faculdade de Medicina, Universidade de São Paulo, São Paulo, 2002. 
ou falha no atendimento, $13 \%$ sobre resultados de cirurgia estética e $17,4 \%$ referiram-se a outros assuntos.

A cirurgia estética, considerada como especialidade isolada, foi a modalidade que mais apresentou pedidos de reparação. $\mathrm{O}$ resultado foi semelhante a um estudo realizado pelo Cremesp em $2007^{25}$, o qual mostrou que a maior taxa de profissionais que sofreram processos judiciais (número de médicos especialistas processados, dividido pelo número de médicos especialistas em atividade, multiplicado pelo tempo de formado) no período de 2000 a 2006 pertenceu aos especialistas em cirurgia plástica.

Consideradas as classificações das outras modalidades de cirurgia relacionadas no estudo do Cremesp ( $3^{\mathrm{a}}$ cirurgia do trauma, $9^{\mathrm{a}}$ cirurgia geral, $11^{\mathrm{a}}$ pediátrica, $12^{\mathrm{a}}$ cardiovascular, $13^{\mathrm{a}}$ do aparelho digestivo, $20^{\mathrm{a}}$ da cabeça e pescoço, $24^{\mathrm{a}}$ vascular e $27^{\mathrm{a}}$ torácica), estima-se que os pedidos de danos decorrentes de cirurgia devem superar as demais modalidades, conforme observado.

Para analisar quais os pedidos de indenização mais freqüentes, foram desconsideradas duas das ações que eram unicamente cautelares, uma vez que por sua natureza não apresentaram pedido condenatório.

O pedido mais comum em todas as ações, observando que cada uma delas poderia apresentar mais de um pedido, foi o de indenização por danos morais (100\%), seguido de lucros cessantes e/ou pedidos de pensão com 19 casos (43,2\%), despesas médicohospitalares e/ou nova cirurgia com 17 casos (38,6\%), devolução de valores pagos com 9 casos $(20,5 \%)$, danos estéticos com 3 casos $(6,8 \%)$ e danos físicos com 2 casos $(4,5 \%)$. Outros pedidos estiveram presentes em 29 casos $(65,9 \%)$.

$\mathrm{O}$ valor mais baixo pedido em sede de danos morais foi de 50 salários mínimos e o mais alto de 5.000 s.m. (não há limites para o que se pode pedir de indenização, ainda mais quando os autores são beneficiários da justiça gratuita). $\mathrm{O}$ valor mais pedido foi de 1.000 salários mínimos, com dez ocorrências, sendo que a média de valores ficou em 1.161 s.m..

O fato de terem sido pedidos valores tão altos não implicou que fossem acolhidos pelo juízo. Conforme se verificou nas sentenças proferidas, o valor mínimo de condenação por danos morais foi de 14 salários mínimos e o valor máximo de 1.000 s.m., sendo que a média foi de 243 salários mínimos.

${ }^{25}$ CONSElHO REGIONAL DE MEDICINA DO ESTADO DE SÃO PAULO. Denúncias e processos relacionados ao exercício profissional da medicina no Estado de São Paulo no periodo de 2000 a 2006. São Paulo, 2007. 
O tempo mínimo observado entre o ajuizamento da ação e a sentença de primeiro grau foi de 1 ano e 9 meses e o máximo de 6 anos e 5 meses, sendo o médio de 3 anos e 9 meses. A complexidade de cada caso em particular, a multiplicidade de partes, o número de processos em andamento na unidade judicial, a pauta de audiências e o tempo de apresentação dos laudos periciais, entre outros fatores, influem no tempo necessário para que uma causa seja julgada.

Após a sentença de primeiro grau, houve recurso em todos os processos, que foram encaminhados ao Tribunal de Justiça para julgamento. Apenas cinco recursos haviam sido julgados até a coleta de dados. O tempo para que o recurso fosse julgado pelo Tribunal variou de 1 anos e 5 meses a 6 anos e 9 meses, com uma média de 4 anos e 2 meses (lembre-se que o número ainda é baixo para se aferir uma média segura).

\subsection{Análise crítica dos conteúdos dos laudos}

Os dois pontos principais examinados consistiram em saber se os laudos apresentaram todos os elementos recomendados e se auxiliaram corretamente na tomada de decisões pelos juízes.

Os elementos iniciais do laudo são a introdução e o histórico. Ambos foram reunidos para fins de estudo, pois se observou que, na prática, muitos peritos colocam o histórico dentro da introdução e vice-versa. Nesta parte do laudo, o perito deve fornecer ao juiz a identificação da pessoa, um breve relato do caso e do problema posto em análise.

Apenas 2 laudos não apresentaram introdução ou histórico do caso. Tais laudos eram bastante sucintos, possuindo o primeiro deles apenas uma página e o segundo apenas três, sendo também considerados deficientes nos demais itens.

O exame físico geral e especial do paciente periciado foi mencionado em 32 laudos e em 6 deles não houve qualquer menção de sua realização. Os 8 exames restantes ficaram prejudicados em razão da morte do paciente, procedendo-se ao chamado exame indireto.

Considera-se essencial que o médico tenha contato direto com a parte periciada, pois nem sempre os documentos dos autos fornecem com exatidão os detalhes dos procedimentos realizados, tampouco eventuais seqüelas. 
O exame dos documentos existentes no processo também deve ser mencionado expressamente pelo perito no laudo, a fim de dar suporte ao seu trabalho. Apesar disso, em 5 laudos $(10,9 \%)$ o perito não fez qualquer menção sobre ter ou não examinado os documentos dos autos.

O autor da ação na maioria das vezes não tem acesso aos documentos necessários para apuração dos fatos, cabendo ao réu trazê-los ou serem requisitados pelo juízo aos estabelecimentos de saúde. Um dos documentos essenciais é, sem dúvida, o prontuário médico.

Outro ponto importante a se notar é que nem sempre o perito judicial tem acesso ao conteúdo completo dos autos judiciais, pois estes costumam ficar armazenados no cartório.

$\mathrm{Na}$ maioria das varas judiciais observa-se que o perito nomeado pelo juízo, que recebe honorários pagos pelas partes, vem em cartório e retira os autos. Entretanto, quando a perícia é realizada em órgão oficial como o IMESC, por exemplo, o perito não tem meios ou recursos para ir a todas as varas judiciais e retirar os processos. Os cartórios então extraem cópias das principais peças dos autos e as encaminham ao órgão onde o perito trabalha.

Tal procedimento pode, eventualmente, não fornecer todas as cópias necessárias e uma visão completa das questões a serem apuradas no processo, cabendo ao perito, caso entenda necessário, solicitar informações complementares ao juízo, às partes ou aos estabelecimentos envolvidos.

Após expor todos os elementos examinados, o perito deve discutir e fundamentar adequadamente seu trabalho, mostrando ao juiz quais são os aspectos levados em conta para determinar se houve dano, qual a extensão deste, a culpa e o nexo causal.

Nos processos analisados foi verificado que 26 laudos (56,5\%) apresentaram uma discussão completa e fundamentada, $12(26,1 \%)$ possuíam uma fundamentação parcial e os 8 restantes $(17,4 \%)$ não tiveram discussão ou fundamentação.

O trabalho pericial deve ter também uma conclusão clara, a fim de auxiliar na decisão do juiz. O perito deve assumir uma posição e indicar ao magistrado se, no seu entender, houve ou não erro médico, ou ainda se é impossível determiná-lo.

Esta parte teve problemas semelhantes à anterior: 29 laudos (63\%) continham uma conclusão clara e 17 (37\%) não a apresentaram. Nestes últimos, como mencionado na exposição de dados, foram incluídos tanto os laudos que não tinham conclusão, como aqueles que se abstiveram de dar sua opinião. 
Foram observados diversos laudos inconclusivos. Um deles, por exemplo, limitouse a descrever os procedimentos, sem dizer se estavam corretos ou não e alegou que "a existência de incúria médica é questão de mérito". Outro afirmou que se tratava de "missão privativa do juiz ou dos Conselhos Regionais de Medicina”. Alguns laudos não conseguiram esclarecer ou ajudar a esclarecer se houve erro na conduta médica prestada.

Ao final do laudo, o perito deve responder os quesitos formulados pelo juiz e pelas partes. Longas digressões devem ser evitadas nesta parte, pois já devem ter sido realizadas na parte da discussão.

Constatou-se que 33 laudos $(71,7 \%)$ o fizeram adequadamente, porém em 9 casos $(19,6 \%)$ o perito não respondeu nenhum quesito e em $3(6,5 \%)$ ele respondeu apenas os quesitos de uma parte, deixando de responder os demais.

Somando-se estes dois últimos valores, em mais de $25 \%$ dos casos os peritos simplesmente entregaram seus laudos sem atentar para as respostas às perguntas feitas no processo, o que certamente demandou atrasos no andamento para que tais omissões fossem sanadas.

Em 28 laudos (60,9\%) foi necessário acionar novamente o perito para responder os quesitos faltantes, prestar esclarecimentos ou realizar laudo complementar. Isto não quer dizer necessariamente que todos estes laudos apresentaram problemas. Muitas vezes a parte que vislumbra uma conclusão desfavorável procura buscar junto ao perito algum elemento que lhe favoreça.

A maioria das perícias, mesmo aquelas realizadas por médicos pertencentes a órgãos públicos, não teve uma redação precisa ou padronizada. Alguns peritos fizeram longas incursões teóricas, outros se limitaram a apenas responder os quesitos formulados pelas partes, outros ainda chegaram a se manifestar juridicamente sobre a causa.

Embora os problemas apresentados tenham sido descritos com maior ênfase, destaca-se que, combinando os percentuais de avaliação da discussão, conclusão e resposta aos quesitos formulados, em torno de 60 a 70\% dos laudos cumpriram bem sua função de auxiliar na decisão do juiz e foram considerados satisfatórios. Os melhores laudos foram aqueles que, em vez de se limitarem a responder os quesitos formulados, forneceram informações úteis e adicionais, pertinentes às matérias examinadas.

Os outros 30 a 40\% consistem em um percentual significativo, que poderá ser melhorado com algumas das sugestões a serem feitas no último item deste capítulo. 


\subsection{Sentenças e acórdãos proferidos}

Nos 46 processos analisados, foram proferidas 24 sentenças. Destas, 14 (54,2\%) julgaram a ação improcedente, $9(41,6 \%)$ procedente em parte e $1(4,2 \%)$ inteiramente procedente. A única ação julgada inteiramente procedente possuía somente pedido de dano moral, enquanto as procedentes em parte possuíam vários pedidos e alguns deles foram acolhidos.

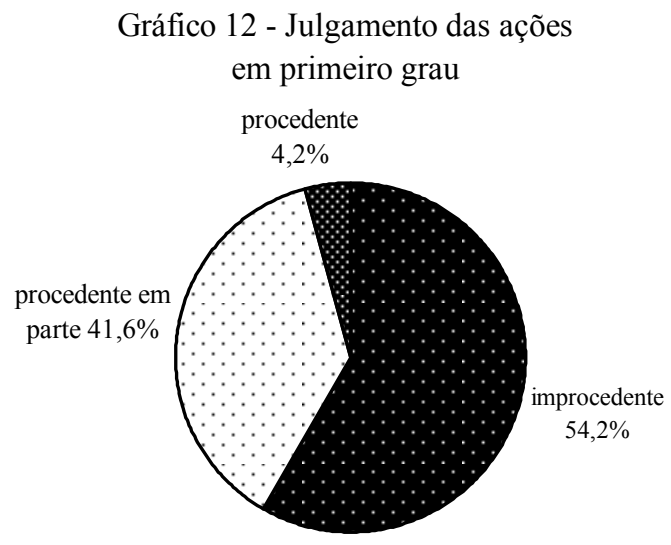

Averiguou-se como se deu a utilização dos laudos nestas sentenças judiciais. Para isso, tal utilização foi classificada em três níveis: integral (casos em que o juiz acolheu integralmente os elementos do laudo - mesmo naqueles que não tinham uma conclusão clara, o magistrado fundamentou-se majoritariamente em alegações presentes no restante do trabalho pericial), parcial (quando o juiz acolheu parcialmente o laudo) e irrelevante (quando o juiz não acolheu o laudo).

Nas 24 sentenças proferidas, 19 acolheram integralmente o laudo (79,2\%), 4 parcialmente (16,6\%) e 1 não acolheu o laudo pericial (4,2\%). Esta única ação será descrita com detalhes adiante. 


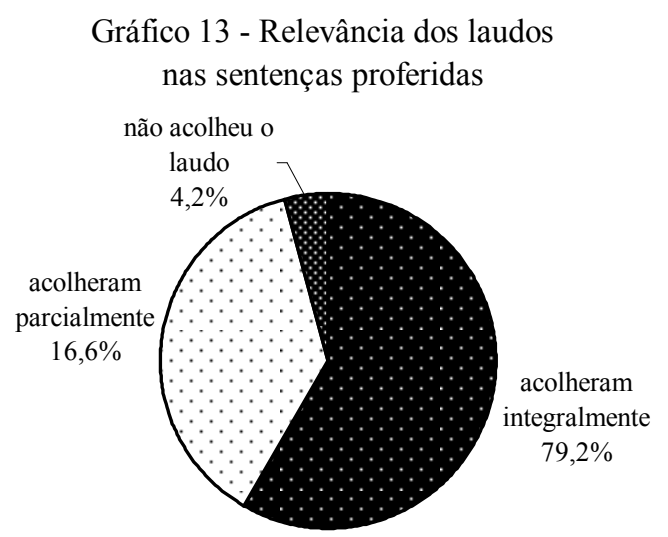

Houve apenas 5 acórdãos proferidos em segunda instância. Destes, 4 confirmaram as sentenças de primeira instância e 1 reformou a sentença que não havia acolhido o laudo e julgado a ação improcedente. Cabe aqui uma rápida exposição deste caso, porque envolve inclusive uma discussão a respeito da especialização dos peritos.

Tratava-se de ação segundo a qual a autora foi submetida a cirurgia de hérnia de disco cervical. Alegou que o médico lesionou a proteção da meninge, a traquéia e o esôfago na primeira cirurgia. Que não houve proteção adequada de sua cama pelo hospital, o que causou uma queda e complicação de seu estado de saúde. Relatou ainda a ocorrência de complicações e que ficou incapacitada para o trabalho.

$\mathrm{O}$ perito judicial afirmou que houve erro de técnica na primeira cirurgia e que o requerido não corrigiu o erro na segunda intervenção. Relatou dano físico, incapacidade laborativa total e permanente, danos estéticos e danos neuropsíquicos. Já o assistente técnico do médico réu alegou que não houve culpa deste e sim intercorrência relativa à migração do enxerto ósseo, provavelmente provocada pela queda da paciente do leito.

A sentença que não acolheu o laudo oficial fundamentou-se no parecer do assistente técnico do réu e de testemunhas, afirmando que o perito judicial não era especialista na área (neurocirurgia), ao contrário do assistente técnico.

No Tribunal de Justiça, os desembargadores converteram o julgamento em diligência para realização de nova perícia oficial por médico especialista em neurocirurgia. Este apresentou laudo que confirmou o nexo causal, porem afirmou considerar que houve apenas complicação de um procedimento cirúrgico de alto risco, que não consistiria em erro médico. 
O acórdão não acolheu a afirmação do segundo perito de que não considerava erro uma complicação de procedimento cirúrgico de alto risco, por não estar fundamentada e por se tratar de mera opinião, insuficiente para descaracterizar o laudo técnico apresentado pelo primeiro perito judicial. Reconheceu a solidariedade da prestadora do plano de saúde, mas não do hospital, que somente prestou serviços de enfermagem, internação e infraestrutura. Entendeu que os tratamentos de fisioterapia e outros deveriam ficar a cargo do plano de saúde e concedeu à autora uma indenização por danos morais.

O caso é emblemático, pois os desembargadores que fizeram parte da turma julgadora concordaram apenas parcialmente com as alegações do segundo laudo, realizado por especialista. Fundamentaram-se eles no primeiro laudo realizado por não-especialista, o qual apontou que o réu não observou os cuidados necessários para a realização do procedimento cirúrgico.

Conclui-se desta análise das sentenças e acórdãos que, apesar das deficiências apresentadas por alguns dos laudos, são eles realmente importantes para a decisão judicial. Os laudos cuja utilização foi parcial acabaram sendo considerados pelos juízes como uma contribuição às demais provas realizadas. Eventuais lacunas decorrentes de deficiência técnica, possibilidade de corporativismo e falta de especialização dos peritos não foram suficientes para influir em desfavor dos autores.

\subsection{A questão da especialização dos peritos}

Deixou-se à parte esta questão, uma vez que nos 46 laudos estudados em apenas 20 os peritos se declararam especialistas na área periciada, enquanto 26 não fizeram tal declaração, gerando aqui um grau de incerteza sobre se eles possuíam ou não tal qualidade.

Em primeiro lugar, não se discute aqui sobre a imprescindibilidade do perito ter graduação em medicina ou então em área estritamente relacionada com o exercício da atividade médica (por exemplo, em casos de mau funcionamento de equipamento médico pode ser necessária perícia de engenharia biomédica).

Outrossim, entende-se ser bastante recomendável que o perito nomeado tenha algum tipo de especialização ou conhecimento específico da matéria periciada. Isto porque 
a medicina brasileira possui mais de 50 especialidades, cada uma podendo apresentar características próprias e peculiares.

Examinando apenas os 20 laudos oferecidos pelos especialistas, 13 (65\%) tiveram discussões e conclusões consideradas satisfatórias e 7 (35\%) insatisfatórias. Nos laudos cujos peritos não se declararam especialistas (reiterando que aqui existe incerteza, posto que não foi possível determinar as respectivas áreas de especialização), de um total de 26, $14(53,8 \%)$ tiveram discussões e conclusões satisfatórias e 12 (46,2\%) insatisfatórias.

Levando a análise para o campo das sentenças, nas 24 sentenças proferidas constatou-se que 8 tiveram seus laudos feitos por peritos que se declararam especialistas e 16 pelos demais.

Destes 8 laudos feitos por especialistas, 7 (87,5\%) foram totalmente acolhidos na sentença e $1(12,5 \%)$ foi parcialmente acolhido. Dos 16 laudos feitos pelos demais peritos, $12(75 \%)$ foram totalmente acolhidos na sentença, $3(18,75 \%)$ foram parcialmente acolhidos e $1(6,25 \%)$ não foi acolhido (este é o caso cujo julgamento foi revertido no Tribunal de Justiça).

Os números aqui apresentados, embora não sejam suficientes para fazer uma análise aprofundada, aliados à boa prática forense, sugerem que os laudos realizados por especialistas na área objeto da perícia tendem a ser melhor confeccionados e acolhidos pelos juízes.

\subsection{Observações e sugestões relativas à elaboração dos laudos periciais}

Aplicando-se a metodologia e os critérios evidenciados neste trabalho, resultaram algumas observações e sugestões para aperfeiçoar a elaboração dos laudos periciais.

A primeira recomendação, já exposta no item anterior, é que o perito nomeado seja especializado por meio de residência médica ou pelo menos tenha conhecimentos específicos, obtidos mediante a realização de cursos, participação em congressos, etc. dentro da área periciada.

Outra sugestão é que os conselhos regionais, universidades e sociedades de especialistas em medicina ofereçam um número maior de cursos de formação para a 
elaboração de laudos periciais em suas respectivas modalidades. Com isso, tais entidades podem também fornecer ao Poder Judiciário relações com os nomes destes peritos.

O cartório judicial deve dar atenção especial no sentido de disponibilizar todos os autos ao perito, e não somente as principais peças, pois a extração destas cópias muitas vezes é realizada de forma deficiente. Caso os autos permaneçam em cartório, recomendase a extração de cópias integrais às custas da parte interessada.

Os laudos periciais devem apresentar no mínimo as seguintes informações: a) introdução, contendo o objetivo da perícia e principais questões a serem analisadas; b) qualificação completa do perito; c) identificação da pessoa a ser examinada; d) histórico detalhado do caso obtido a partir do exame dos documentos constantes do processo, investigações, pesquisas e diligências; e) exame físico geral e especial ou, no caso de impossibilidade, a forma de realização da perícia indireta; f) discussão fundamentada; g) conclusão; h) respostas aos quesitos do juiz e das partes.

Por fim, o perito deve usar da maior clareza possível para apresentar seu trabalho, buscando não apenas responder os quesitos formulados, mas também fornecer informações adicionais úteis e pertinentes às matérias examinadas. 


\section{CONCLUSÕES}

Nas ações de responsabilidade civil por alegado erro médico, o dano e o nexo causal estão sempre presentes como requisitos do dever de indenizar. Com exceção dos casos de responsabilidade objetiva e das obrigações de resultado, também se exige a demonstração de dolo ou culpa, esta nas modalidades negligência, imprudência ou imperícia.

Os principais tipos de provas que podem ser usadas para apurar o erro médico são: depoimento pessoal, confissão, prova documental, prova testemunhal, prova pericial e inspeção judicial.

O requisito mínimo recomendado para nomeação do perito que irá apurar o erro médico é que tenha graduação em medicina ou em área relacionada a esta. São desejáveis ainda especialização e conhecimentos específicos sobre perícia.

A execução dos trabalhos periciais não depende apenas da qualificação do perito, mas também da obtenção dos documentos necessários, sendo o principal deles o prontuário médico, além de exame físico da parte, pesquisas e diligências.

Caso os laudos do perito oficial e dos assistentes técnicos sejam antagônicos, ou quando entender que a matéria não lhe parece suficientemente esclarecida, o juiz pode se valer de perito desempatador.

Uma porcentagem significativa dos laudos periciais observados não apresentou elementos essenciais, tais como: introdução, exame físico geral e especial, exame dos documentos do processo, discussão fundamentada e conclusão clara. Em mais da metade dos laudos o perito foi acionado para responder os quesitos faltantes, prestar esclarecimentos ou realizar laudo complementar.

Não se conseguiu encontrar um critério uniforme utilizado pelos peritos para avaliar se o médico atuou ou não com negligência, imprudência ou imperícia, ou mesmo para a determinação do nexo causal. Os elementos da responsabilidade civil passíveis de apuração com maior grau de certeza foram os danos físicos, estéticos e materiais e os casos de evidente inobservância de regras técnicas.

Constataram-se três níveis de utilização do laudo nas sentenças: integral, parcial e irrelevante. Cerca de $80 \%$ das sentenças acolheram integralmente os respectivos laudos e $16 \%$ os acolheram parcialmente. 
O papel da perícia é importante como meio de prova, porém esta pode apresentar falhas e/ou imperfeições, devendo o juiz estar sempre atento aos fatos do processo para, caso necessário, formar sua conviç̧ão com outros elementos demonstrados nos autos. 


\section{REFERÊNCIAS}

ALCÂNTARA, Hermes Rodrigues de et al. Perícia médica judicial. 2. ed. Rio de Janeiro: Editora Guanabara Koogan, 2006. 483 p.

ALMEIDA, Alessandra Juttel. É possível a cumulação entre dano moral e dano estético? Disponível em: $\quad<$ http://www.correioforense.com.br/anexos/danomoral/ 1139832093670.doc >. Acesso em: 20 nov. 2008.

BARROS, Felipe Luiz Machado. O dano estético e a responsabilização civil. Jus Navigandi, Teresina, ano 5, n. 49, fev. 2001. Disponível em: $<$ http://jus2.uol.com.br/doutrina/texto.asp?id=1870>. Acesso em: 20 nov. 2008.

BENJAMIN, Antonio Herman de Vasconcelos. Comentários ao Código do Consumidor. São Paulo: Editora Saraiva, 1991.

BITTAR, Eduardo C.B. Metodologia da pesquisa jurídica. 6. ed. São Paulo: Editora Saraiva, 2007. 261 p.

CINTRA, Antônio Carlos de Araújo; GRINOVER, Ada Pellegrini; DINAMARCO, Cândido Rangel. Teoria Geral do Processo. 19. ed. rev. e atual. São Paulo: Malheiros Editores, 2002. p. 348-352.

CONSELHO REGIONAL DE MEDICINA DO ESTADO DE SÃO PAULO. Denúncias e processos relacionados ao exercício profissional da medicina no Estado de São Paulo no período de 2000 a 2006. São Paulo, 9 out. 2007. Disponível em: $<$ http://www.cremesp.org.br/library/modulos/centro_de_dados/arquivos/denuncias cremes p.pdf>. Acesso em: 20 nov. 2008. 
CONSELHO REGIONAL DE MEDICINA DO ESTADO DE SÃO PAULO. Especialidades médicas no Estado de São Paulo. São Paulo, 2008. Disponível em: $<$ http://www.cremesp.org.br/library/modulos/centro_de_dados/arquivos/especialidades.pdf >. Acesso em: 20 nov. 2008.

CONSELHO REGIONAL DE MEDICINA DO ESTADO DE SÃO PAULO. $O$ trabalho do médico no Estado de São Paulo. São Paulo, 2007. Disponível em: $<$ http://www.cremesp.org.br/library/modulos/centro de dados/arquivos/mercado de traba lho.pdf $>$. Acesso em: 20 nov. 2008.

CONSELHO REGIONAL DE MEDICINA DO ESTADO DE SÃO PAULO. Perfil do médico. São Paulo, 2007. Disponível em: < $\underline{\text { http://www.cremesp.org.br/library/modulos/ }}$ centro de dados/arquivos/perfil_medico.pdf>. Acesso em: 20 nov. 2008.

COUTO FILHO, Antonio Ferreira; SOUZA, Alex Pereira. Responsabilidade civil médica e hospitalar. 2. ed. Rio de Janeiro: Editora Lumen Juris, 2008. 677 p.

COUTO FILHO, Antonio Ferreira; SOUZA, Alex Pereira. A improcedência no suposto erro médico. 2. ed. rev., atual. e ampl. Rio de Janeiro: Editora Lumen Juris, 2002. p. 1-43.

DINAMARCO, Cândido Rangel. Instituições de Direito Processual Civil. 4. ed. rev. e atual. São Paulo: Malheiros Editores, 2004. p. 564-597.

DINIZ, Maria Helena. Curso de Direito Civil Brasileiro - Responsabilidade Civil. V. 7, 22. ed. São Paulo: Saraiva, 2008.

FRANÇA, Genival Veloso de. A perícia do erro médico. Disponível em: $<\underline{\text { http://www.erromedico.org/genival_pericia.htm> }}$. Acesso em: 20 nov. 2008. 
FRANÇA, Genival Veloso de. Direito médico. 6. ed. São Paulo: Fundação BYK, 1994. p. 232-270.

FRANÇA, Genival Veloso de. Medicina Legal. 8. ed. Rio de Janeiro, Editora Guanabara Koogan, 2008. 629 p.

GONÇALVES, Carlos Roberto. Responsabilidade civil. 6. ed. São Paulo: Editora Saraiva, 1995. $686 \mathrm{p}$.

KFOURI NETO, Miguel. Culpa médica e ônus da prova. São Paulo: Editora Revista dos Tribunais, 2002. p. 32-205.

KFOURI NETO, Miguel. Responsabilidade civil do médico. 6. ed. São Paulo: Editora Revista dos Tribunais, 2007. 606 p.

LOPES, João Batista. A prova no direito processual civil. 2. ed. rev., atual. e ampl. São Paulo: Editora Revista dos Tribunais, 2002. p. 111-140.

LOPES, Tereza Ancona. O dano estético: responsabilidade civil. 3. ed. São Paulo: Editora Revista dos Tribunais, 2004.

MELO, Nehemias Domingos de. Responsabilidade Civil por Erro Médico. 1. ed. São Paulo: Editora Atlas, 2008. 231 p.

MEZZAROBA, Orides; MONTEIRO, Cláudia Servilha. Manual de metodologia da pesquisa no Direito. 3. ed. São Paulo: Editora Saraiva, 2007. 344 p.

MORAES, Irany Novah. Erro Médico e a Justiça. 5. ed. rev., atual. e ampl. São Paulo: Editora Revista dos Tribunais, 2003. p. 420-677. 
NEMETZ, Luiz Carlos; FRAGA, Flávio. O valor da prova pericial nas ações de erro médico. Boletim Jurídico, n. 155, dez. 2005. Disponível em:

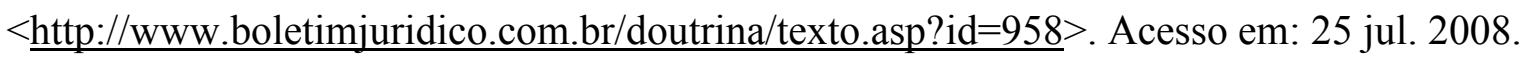

RIBEIRO, Alex Sandro. Não se cumulam “danos estéticos” com danos morais e/ou materiais. Revista Ambito Jurídico, Rio Grande, n. 15, nov. 2003. Disponível em $<\underline{\text { http://www.ambito-juridico.com.br/site/index.php?n_link=revista_artigos_leitura\&artigo }}$ id $=4040>$. Acesso em 20 nov. 2008.

ROCHA, Cleonice Rodrigues Casarin da. A responsabilidade civil decorrente do contrato de serviços médicos. Rio de Janeiro: Forense, 2005. p. 289-402.

ROMANELLO NETO, Jerônimo. Responsabilidade civil dos médicos. São Paulo: Editora Jurídica Brasileira, 1998. p. 167-176.

SALAMACHA, Consuelo Taques Ferreira. Erro médico: inversão do ônus da prova. 2. ed. Curitiba: Juruá, 2008. 159 p.

SEBASTIÃO, Jurandir. Responsabilidade médica civil, criminal e ética: legislação positiva aplicável. Belo Horizonte: Del Rey, 1998. p. 29-38.

SOUZA, Neri Tadeu Camara. Responsabilidade civil no erro médico. Disponível

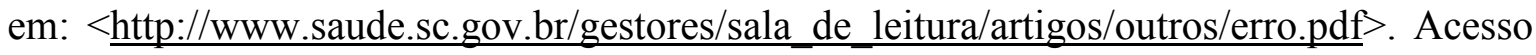
em: 20 nov. 2008.

STOCO, Rui. Tratado de responsabilidade civil. 6. ed. rev., atual. e ampl. São Paulo: Editora Revista dos Tribunais, 2004. p. 527-565. 
THEODORO JÚNIOR, Humberto. Aspectos processuais da ação de responsabilidade por erro médico. Revista de Processo, n. 95. 05 dez. 2005. São Paulo: Editora Revista dos Tribunais, 1999.

UDELSMANN, Artur. Responsabilidade civil, penal e ética dos médicos. Revista da Associação Médica Brasileira, vol. 48, n. 2, abr./jun. 2002. Disponível em: $<$ http://www.scielo.br/scielo.php?script=sci arttext\&pid=S0104-42302002000200039 $>$. Acesso em: 20 nov. 2008.

WAMBIER, Luiz Rodrigues (Coord.); ALMEIDA, Flávio Renato Correia de; TALAMINI, Eduardo. Curso avançado de processo civil, volume 1: teoria geral do processo e processo de conhecimento. 8. ed. rev., atual. e ampl. São Paulo: Editora Revista dos Tribunais, 2006. p. 422-447. 


\begin{tabular}{|c|c|c|c|c|c|c|c|c|c|c|c|c|c|}
\hline 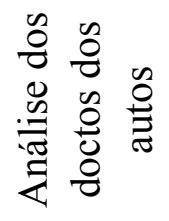 & 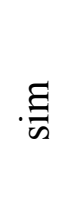 & . & . & 晒 & 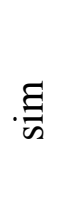 & . & 园 & 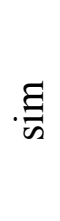 & 看 & 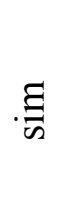 & . & $\Xi$ & . \\
\hline 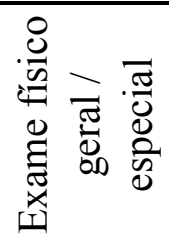 & . & . & . & $\Xi$ & . & $\Xi$ & . & . & . & . & $\Xi$ & 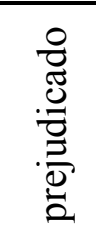 & 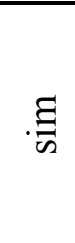 \\
\hline 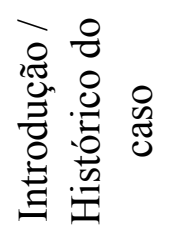 & $\Xi$ & . & . & .尹 & . & . & . & . & . & . & . & $\Xi$ & . \\
\hline 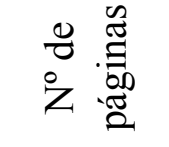 & $n$ & $\stackrel{0}{0}$ & N & $\stackrel{0}{0}$ & $\nabla$ & N & $n$ & $\nabla$ & $\stackrel{n}{n}$ & $\widehat{\sim}$ & 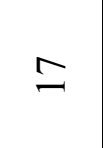 & $\infty$ & $\beth$ \\
\hline 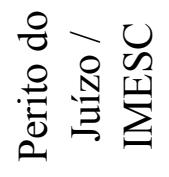 & 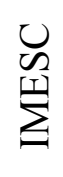 & $\begin{array}{l}U \\
\mathscr{U} \\
\pm \\
\sum\end{array}$ & 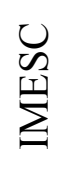 & 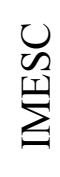 & $\begin{array}{l}U \\
\mathscr{W} \\
\sum_{1}\end{array}$ & $\begin{array}{l}\circlearrowright \\
\mathscr{W} \\
\sum \\
\sum\end{array}$ & $\begin{array}{l}\stackrel{0}{N} \\
\stackrel{0}{\Xi} \\
0\end{array}$ & $\begin{array}{l}U \\
\mathscr{D} \\
\sum \\
\sum\end{array}$ & $\begin{array}{l}\stackrel{0}{N} \\
\stackrel{\Xi}{\Xi} \\
0 \\
\end{array}$ & $\begin{array}{l}\stackrel{0}{N} \\
\stackrel{0}{\Xi} \\
0\end{array}$ & $\begin{array}{l}\stackrel{0}{N} \\
\stackrel{0}{\Xi} \\
0\end{array}$ & 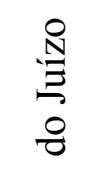 & $\begin{array}{l}\stackrel{8}{N} \\
: \\
0 \\
0\end{array}$ \\
\hline 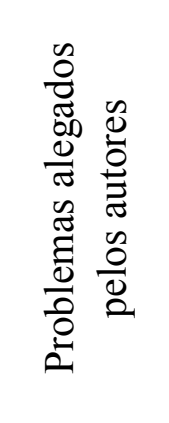 & 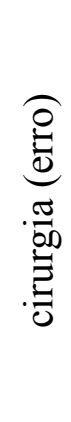 & 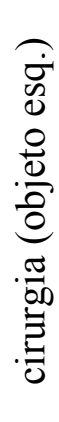 & 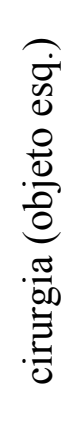 & 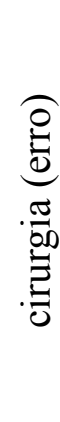 & 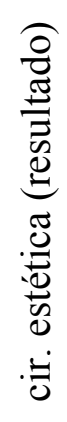 & 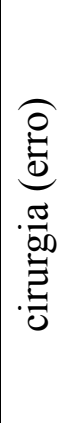 & 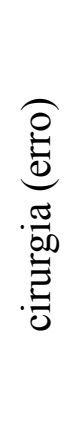 & 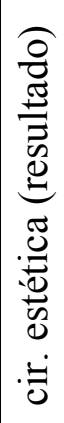 & 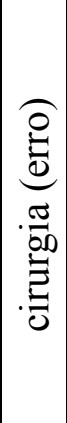 & 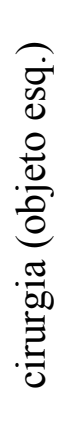 & 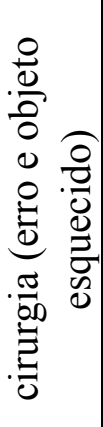 & 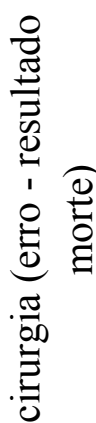 & 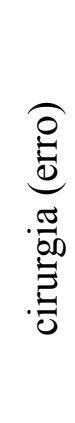 \\
\hline 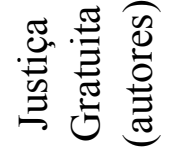 & $\Xi$ & $\Xi$ & 目 & $\Xi$ & 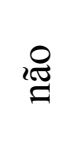 & $\Xi$ & $\Xi$ & . & 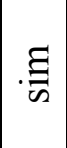 & . & $\Xi$ & 决 & $\stackrel{2}{\stackrel{2}{\Xi}}$ \\
\hline 造 & $\hat{\sim}$ & $\tilde{\omega}$ & $\frac{\hat{s}}{\sim}$ & 葛 & $\hat{\sim}$ & 告 & $\frac{\hat{s}}{\sim}$ & $\tilde{\omega}$ & $\hat{\sim}$ & $\hat{\sim}$ & 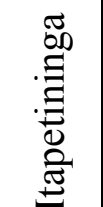 & $\hat{\sim}$ & $\hat{s}$ \\
\hline $\begin{array}{l}0 \\
0 \\
0 \\
0 \\
0 \\
0 \\
0 \\
0 \\
0 \\
0 \\
0 \\
Z\end{array}$ & $\frac{\hat{a}}{\stackrel{2}{a}}$ & 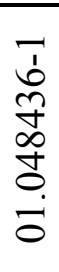 & 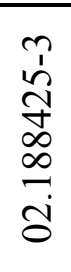 & $\begin{array}{l}\frac{1}{o} \\
\frac{\infty}{\alpha}\end{array}$ & $\begin{array}{l}7 \\
\infty \\
\\
\vdots \\
0 \\
\dot{0}\end{array}$ & 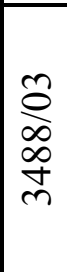 & 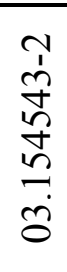 & $\begin{array}{l}1 \\
0 \\
0 \\
0 \\
\infty \\
\infty \\
0 \\
\dot{0}\end{array}$ & $\begin{array}{l}\infty \\
1 \\
n \\
n \\
6 \\
0 \\
0 \\
0 \\
0\end{array}$ & $\begin{array}{l}n \\
\infty \\
\Xi \\
\bar{\Xi} \\
0 \\
\dot{0}\end{array}$ & 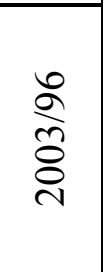 & \begin{tabular}{l}
0 \\
1 \\
\multirow{1}{*}{} \\
6 \\
0 \\
0 \\
0 \\
0
\end{tabular} & 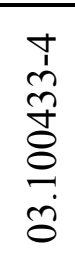 \\
\hline
\end{tabular}




\begin{tabular}{|c|c|c|c|c|c|c|c|c|c|}
\hline 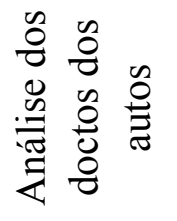 & .g & . & İ &.$\Xi$ & . & .g & . & .g & . \\
\hline 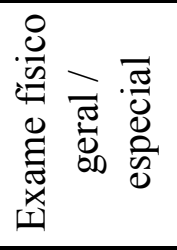 & . & 욤 & Iత్త & i્̊తి & . &.$\Xi$ & . & . & 哮 \\
\hline 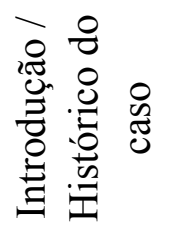 & . & . & iత్తి & . & . &.$\Xi$ & . &.$\Xi$ & . \\
\hline 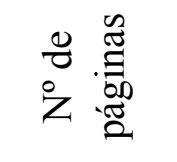 & $\stackrel{\varrho}{=}$ & 으 & - & $\stackrel{0}{ }$ & $m$ & $a$ & $m$ & $\nabla$ & $\underset{7}{\forall}$ \\
\hline 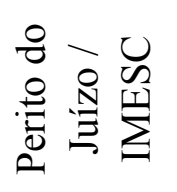 & 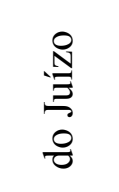 & $\begin{array}{l}\stackrel{0}{N} \\
\stackrel{N}{\Xi} \\
0 \\
0\end{array}$ & 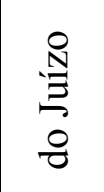 & $\begin{array}{l}\stackrel{\circ}{N} \\
\stackrel{\Xi}{\Xi} \\
\stackrel{0}{0}\end{array}$ & $\begin{array}{l}U \\
\mathscr{W} \\
\sum \\
\sum\end{array}$ & 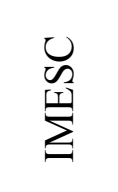 & $\begin{array}{l}\circlearrowright \\
\mathscr{W} \\
\sum\end{array}$ & 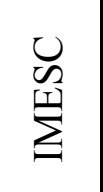 & $\begin{array}{l}\stackrel{0}{N} \\
\stackrel{\Xi}{\Xi} \\
0 \\
0\end{array}$ \\
\hline 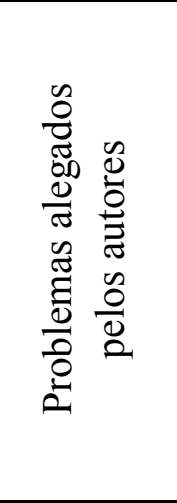 & 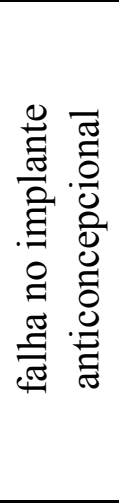 & 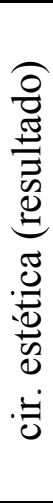 & 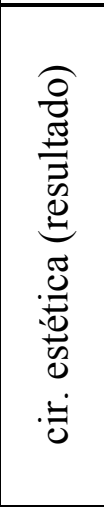 & 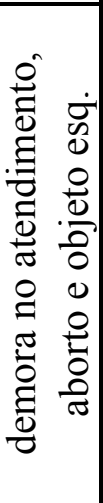 & 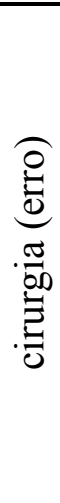 & 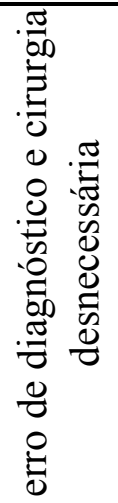 & 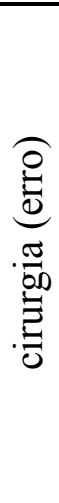 & 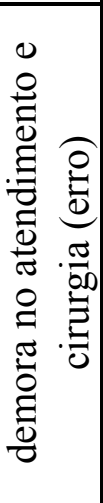 & 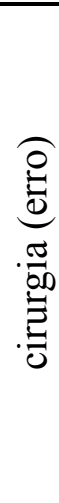 \\
\hline 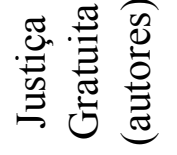 & . & $\Xi$ & I: &.$\Xi$ & . & . & . & 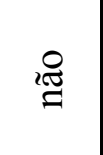 & $\Xi$ \\
\hline 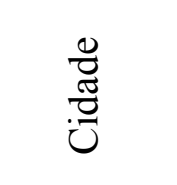 & 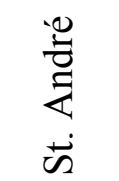 & $\hat{\sim}$ & 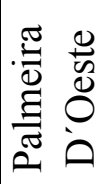 & $\hat{\sim}$ & 䔍 & $\hat{\sim}$ & $\hat{\sim}$ & $\ddot{\sim}$ & $\hat{\sim}$ \\
\hline $\begin{array}{l}0 \\
0 \\
0 \\
0 \\
0 \\
0 \\
0 \\
0 \\
0 \\
0 \\
0 \\
Z\end{array}$ & $\frac{n}{2}$ & 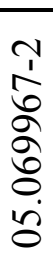 & $\frac{\hat{0}}{\hat{0}}$ & $\begin{array}{l}+ \\
1 \\
\infty \\
0 \\
+0 \\
0 \\
= \\
0\end{array}$ & 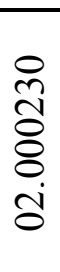 & 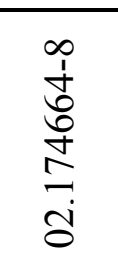 & 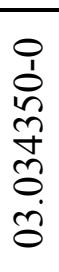 & 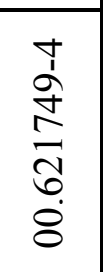 & 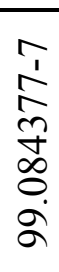 \\
\hline
\end{tabular}




\begin{tabular}{|c|c|c|c|c|c|c|c|c|c|}
\hline 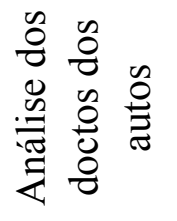 & .छ & .g &.$\Xi$ & .g &.$\Xi$ &.$\Xi$ &.$\Xi$ & $\Xi \Xi$ & . \\
\hline 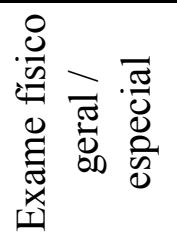 & 2I્తి & 陆 & 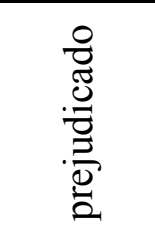 & .尹 & . & 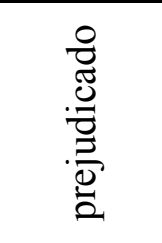 & 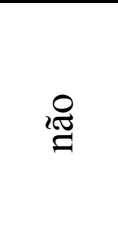 & .g & 哮 \\
\hline 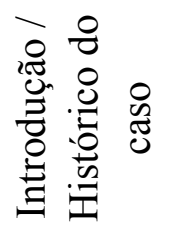 & . & 見 & .尹 &.$\Xi$ & . & . & . &.$\Xi$ & . \\
\hline 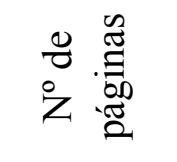 & $=$ & $m$ & $\stackrel{\infty}{\sim}$ & $\bar{\sim}$ & 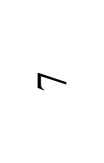 & 6 & n & $\infty$ & $r$ \\
\hline 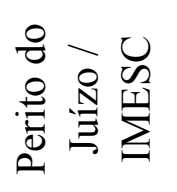 & $\begin{array}{l}\stackrel{0}{1} \\
\stackrel{3}{3} \\
0\end{array}$ & 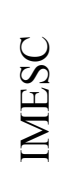 & 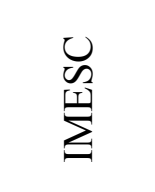 & 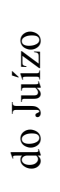 & 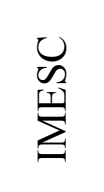 & 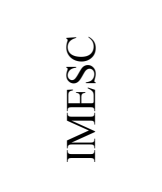 & $\begin{array}{l}\stackrel{0}{N} \\
\stackrel{\Xi}{3} \\
0 \\
0\end{array}$ & $\begin{array}{l}\stackrel{8}{N} \\
\stackrel{3}{8} \\
8\end{array}$ & $\begin{array}{l}\stackrel{0}{N} \\
. \\
0 \\
0\end{array}$ \\
\hline 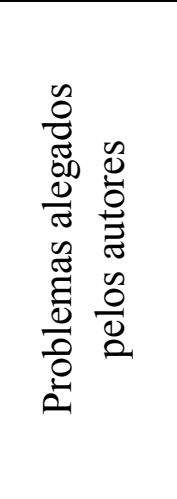 & 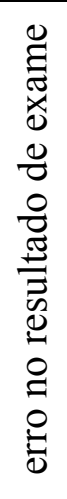 & 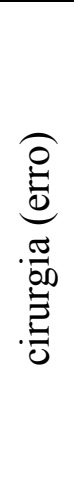 & 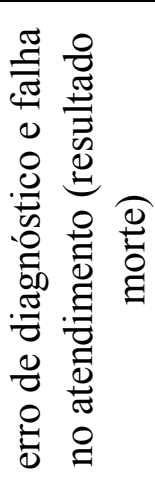 & 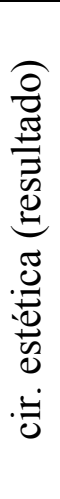 & 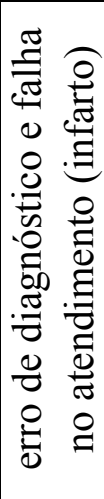 & 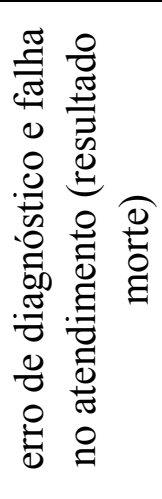 & 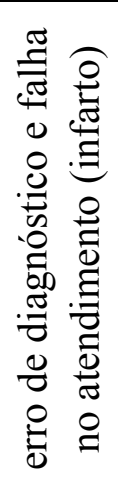 & 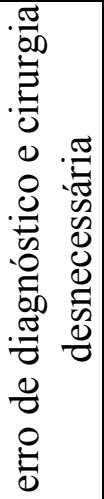 & 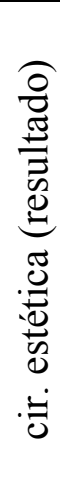 \\
\hline 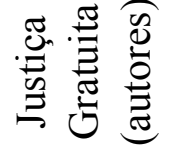 & . & . & . & 胥 & . & . & . & . & $\Xi$ \\
\hline 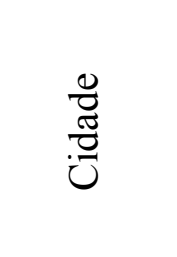 & $\hat{\sim}$ & 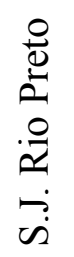 & $\hat{\sim}$ & $\hat{\sim}$ & $\ddot{\sim}$ & $\bar{\sim}$ & $\hat{\sim}$ & $\begin{array}{l}\tilde{O} \\
0\end{array}$ & $\vec{\sim}$ \\
\hline $\begin{array}{l}0 \\
0 \\
0 \\
0 \\
0 \\
0 \\
0 \\
0 \\
0 \\
0 \\
i\end{array}$ & 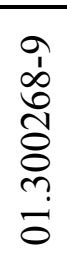 & 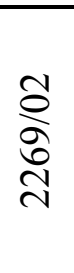 & 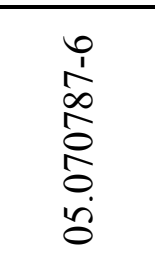 & 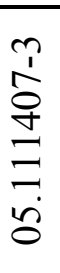 & $\begin{array}{l}n \\
n \\
\infty \\
\infty \\
n \\
\infty \\
2 \\
\sigma\end{array}$ & 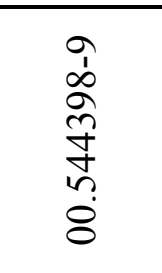 & 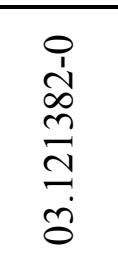 & 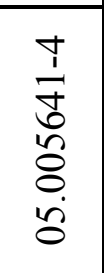 & $\begin{array}{l}n \\
1 \\
\infty \\
0 \\
0 \\
n \\
0 \\
0\end{array}$ \\
\hline
\end{tabular}




\begin{tabular}{|c|c|c|c|c|c|c|c|c|}
\hline 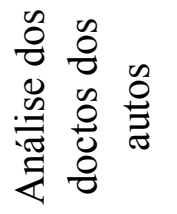 & $\Xi \Xi$ & .尹 & . & זత્తి & .I & . & .छ & $\stackrel{\text { III }}{=}$ \\
\hline 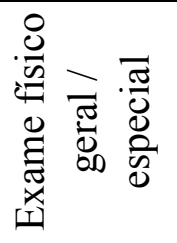 & 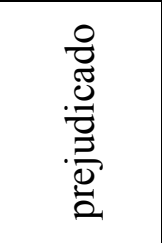 & . & . & 2త్తి & . & .尹 & .छ & $\begin{array}{l}\frac{0}{0} \\
\frac{0}{0} \\
\frac{0}{0} \\
. \frac{7}{0} \\
0\end{array}$ \\
\hline 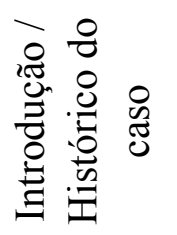 & $\Xi$ & . & . & . & . & .尹 & .छ & 2: \\
\hline 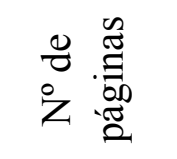 & $a$ & $n$ & $\infty$ & $N$ & $\nabla$ & $\widetilde{\sim}$ & $\gamma$ & $m$ \\
\hline 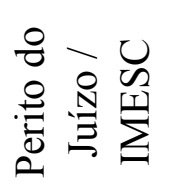 & 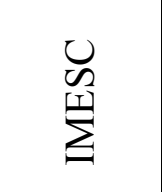 & $\begin{array}{l}\circlearrowright \\
\infty \\
\sum \\
\sum\end{array}$ & 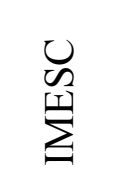 & $\begin{array}{l}\circlearrowright \\
\mathscr{W} \\
\sum\end{array}$ & 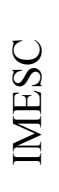 & $\begin{array}{l}\stackrel{0}{N} \\
\stackrel{3}{\Xi} \\
0\end{array}$ & 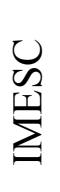 & $\begin{array}{l}\stackrel{8}{N} \\
\stackrel{.}{\Xi} \\
0\end{array}$ \\
\hline 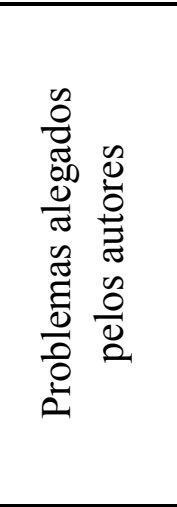 & 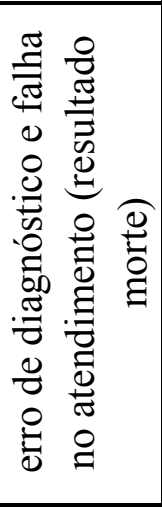 & 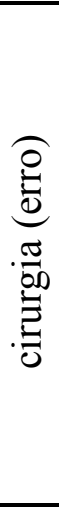 & 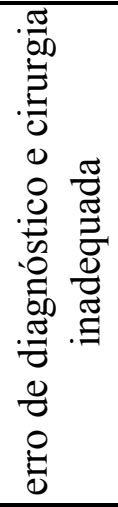 & 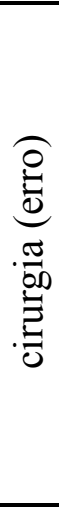 & 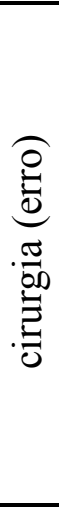 & 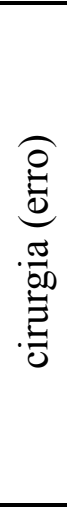 & 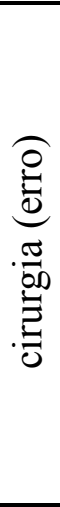 & 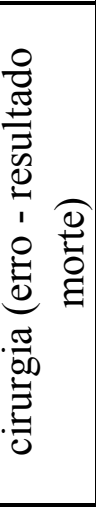 \\
\hline 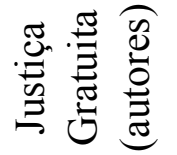 & $\Xi$ & . & . & . & . & 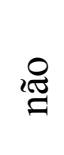 & .छ & . \\
\hline $\begin{array}{l}\frac{\pi}{\pi} \\
\frac{\pi}{0}\end{array}$ & 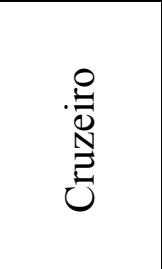 & 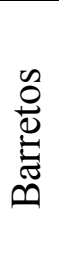 & $\hat{\sim}$ & 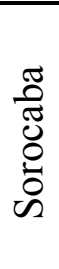 & $\hat{\sim}$ & $\hat{\sim}$ & $\ddot{\infty}$ & 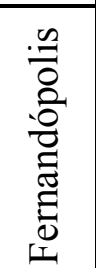 \\
\hline $\begin{array}{l}0 \\
0 \\
0 \\
0 \\
0 \\
0 \\
0 \\
0 \\
0 \\
0 \\
\vdots\end{array}$ & $\frac{\stackrel{d}{\jmath}}{\frac{J}{\sigma}}$ & $\frac{\dot{d}}{\stackrel{\infty}{\sigma}}$ & 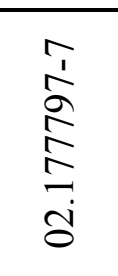 & $\begin{array}{l}\frac{J}{m} \\
\stackrel{1}{=}\end{array}$ & 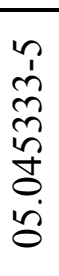 & 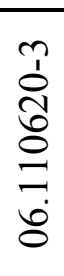 & $\begin{array}{l}\infty \\
1 \\
\dot{1} \\
0 \\
\infty \\
0 \\
0 \\
0 \\
\dot{0} \\
0\end{array}$ & \begin{tabular}{l}
0 \\
1 \\
\\
\multirow{1}{5}{} \\
8 \\
0 \\
0
\end{tabular} \\
\hline
\end{tabular}




\begin{tabular}{|c|c|c|c|c|c|c|c|}
\hline 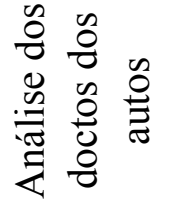 & .g & .g & .g & 2త్తి & . & . & İ్ \\
\hline 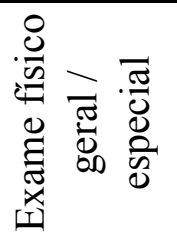 &.$\Xi$ &.$g$ & . & 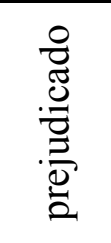 & 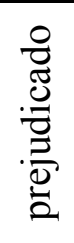 & . & 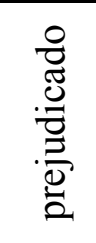 \\
\hline 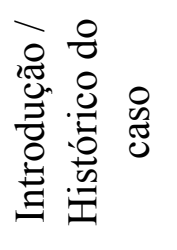 &.$\Xi$ &.$\Xi$ &.$\Xi$ & .g &.$\Xi$ &.$\Xi$ & $\cdot g \frac{\Xi}{\infty}$ \\
\hline 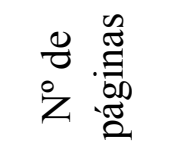 & 6 & $\nabla$ & $\nabla$ & $\nabla$ & in & $\stackrel{工}{工}$ & $\nabla$ \\
\hline 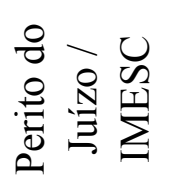 & 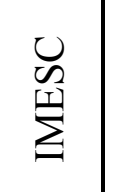 & 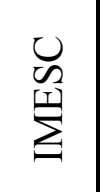 & $\begin{array}{l}U \\
\mathscr{W} \\
\text { II }\end{array}$ & $\begin{array}{l}U \\
\mathscr{W} \\
\text { II }\end{array}$ & $\begin{array}{l}\stackrel{\mathcal{N}}{\Xi} \\
\stackrel{0}{0}\end{array}$ & 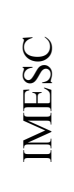 & 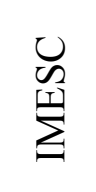 \\
\hline 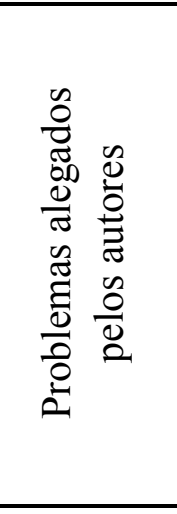 & 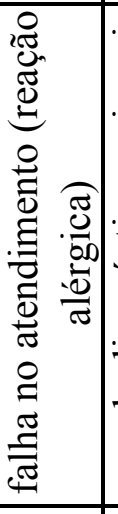 & 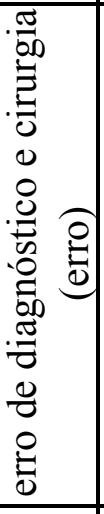 & 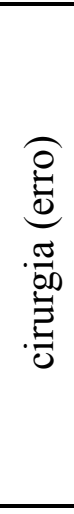 & 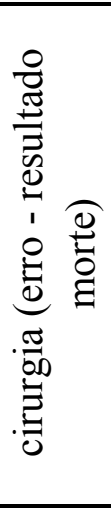 & 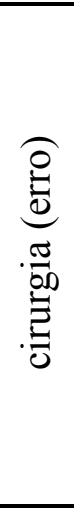 & 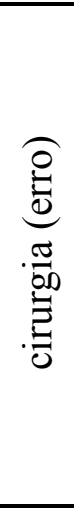 & 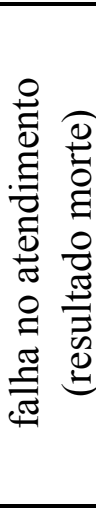 \\
\hline 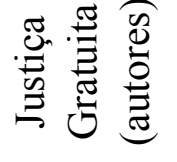 &.$\Xi$ & 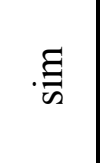 & .g & 2త్తి & . & .g & $\Xi$ \\
\hline $\begin{array}{l}\frac{\pi}{0} \\
\frac{\pi}{0}\end{array}$ & $\hat{\sim}$ & $\hat{\sim}$ & $\hat{\sim}$ & $\hat{\sim}$ & 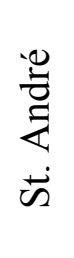 & 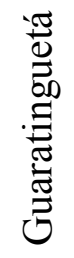 & 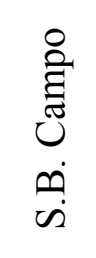 \\
\hline $\begin{array}{l}0 \\
0 \\
0 \\
0 \\
0 \\
0 \\
0 \\
0 \\
0 \\
0 \\
\vdots\end{array}$ & 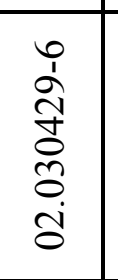 & $\begin{array}{l}0 \\
\stackrel{1}{1} \\
0 \\
0 \\
0 \\
0 \\
\qquad \\
0\end{array}$ & 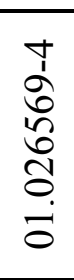 & $\begin{array}{l}\infty \\
1 \\
\infty \\
\infty \\
\sigma \\
= \\
\infty\end{array}$ & $\begin{array}{l}\hat{1} \\
o \\
\infty \\
2 \\
\delta \\
\dot{0}\end{array}$ & $\begin{array}{l}\frac{a}{a} \\
\text { ñ }\end{array}$ & 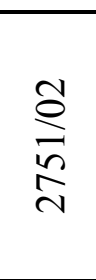 \\
\hline
\end{tabular}




\begin{tabular}{|c|c|c|c|c|c|c|c|c|c|c|c|c|c|}
\hline 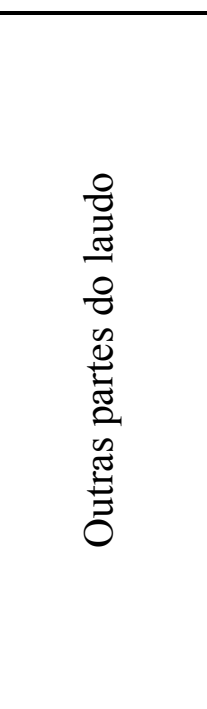 & ' & ' & ' & ' & 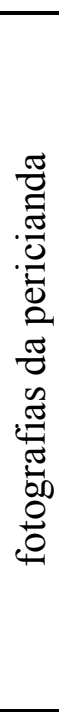 & 1 & ' & 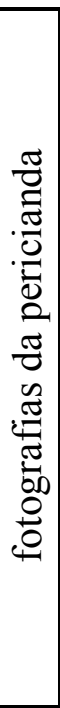 & 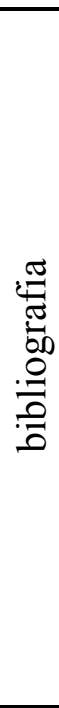 & 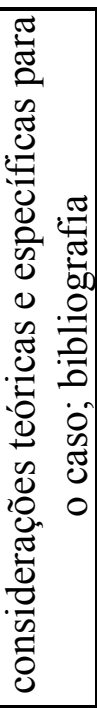 & ' & ' & 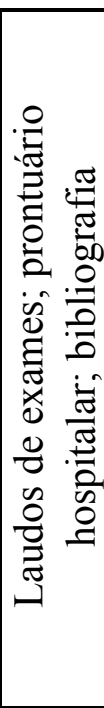 \\
\hline 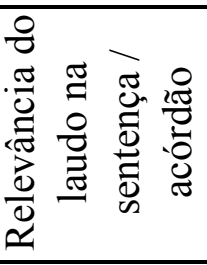 & .छ & 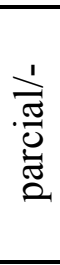 & 1 & 当 & I & I & ' & .̇ & 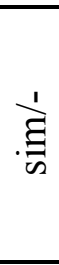 & 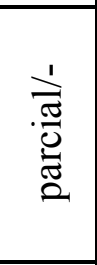 & 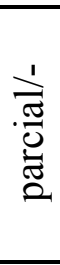 & ' & .̇े \\
\hline 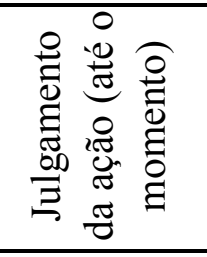 & 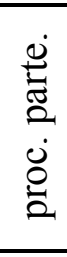 & 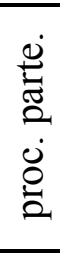 & ' & $\begin{array}{l}\text { ठ̊̆ } \\
\text { : }\end{array}$ & ' & ' & ' & $\begin{array}{l}\text { o̊ } \\
\text { : } \\
\text {. }\end{array}$ & $\begin{array}{l}\text { ठ̊ } \\
\text { : } \\
\text {. }\end{array}$ & 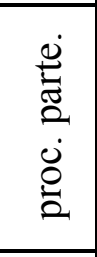 & 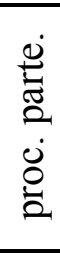 & ' & 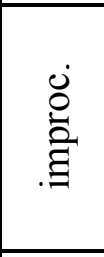 \\
\hline 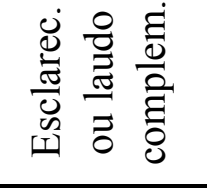 & 孞 & 跑 &.$\Xi$ & 访 & .g & . & . & .g & 跑 & . & .g & 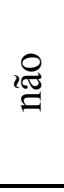 & . \\
\hline 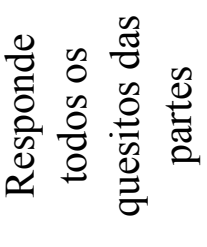 & 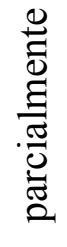 &.$\Xi$ & 痣 &.$\Xi$ & . & . & 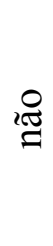 & $\stackrel{\text { II }}{\Xi}$ & . &.$\Xi$ & . &.$\Xi$ & . \\
\hline 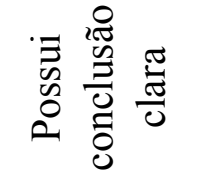 &.$\Xi$ & 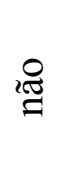 & Iత્త & 谂 & . & . & . & .g & 洁 & Iత్త &.$\Xi$ & 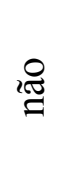 & . \\
\hline 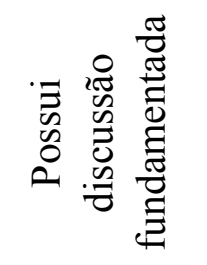 & . & 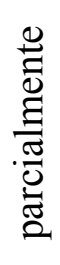 & $\stackrel{\mathbb{I}}{\Xi}$ & II & .g & . & . & .g & . & 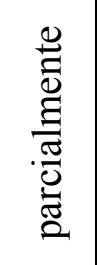 & .g & 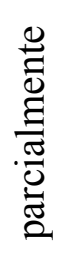 & . \\
\hline $\begin{array}{l}0 \\
0 \\
0 \\
0 \\
0 \\
0 \\
0 \\
0 \\
0 \\
\dot{Z}\end{array}$ & $\frac{\hat{a}}{\frac{a}{2}}$ & $\begin{array}{l}\overrightarrow{1} \\
b \\
\dddot{m} \\
\infty \\
\dot{0} \\
\dot{j}\end{array}$ & \begin{tabular}{l}
$\hat{1}$ \\
$\stackrel{1}{1}$ \\
\multirow{\infty}{\infty}{} \\
$\infty$ \\
$\stackrel{1}{0}$
\end{tabular} & $\begin{array}{l}\stackrel{\Im}{a} \\
\stackrel{2}{\alpha}\end{array}$ & $\begin{array}{l}7 \\
\infty \\
\vdots \\
\vdots \\
0 \\
\dot{0} \\
0\end{array}$ & $\begin{array}{l}0 \\
0 \\
\infty \\
\infty \\
+ \\
m\end{array}$ & 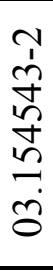 & $\begin{array}{l}1 \\
0 \\
\delta \\
0 \\
\infty \\
0 \\
0 \\
0\end{array}$ & $\begin{array}{l}\infty \\
1 \\
n \\
n \\
\hat{n} \\
0 \\
0 \\
0 \\
0 \\
0\end{array}$ & 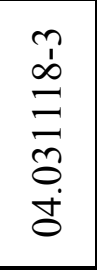 & $\frac{0}{2}$ & $\begin{array}{l}\frac{0}{1} \\
\frac{1}{1} \\
0 \\
2 \\
0 \\
0 \\
0\end{array}$ & 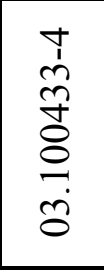 \\
\hline
\end{tabular}




\begin{tabular}{|c|c|c|c|c|c|c|c|c|c|}
\hline 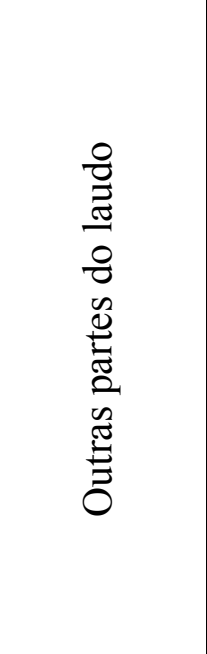 & 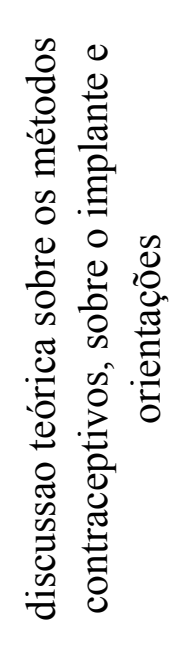 & ' & I & ' & 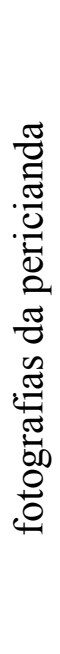 & ' & I & ' & 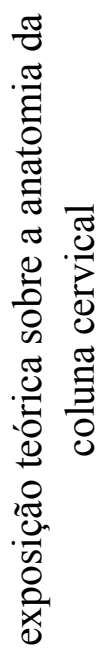 \\
\hline 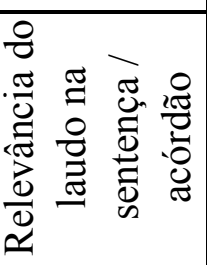 & 官 & है & .ं & .̇ & 官 & 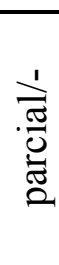 & ' & $\frac{\text {. }}{\text { है }}$ & 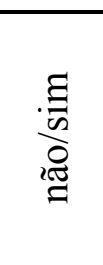 \\
\hline 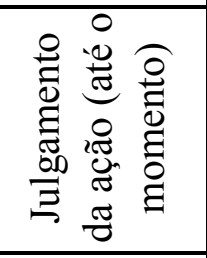 & $\begin{array}{l}\text { : } \\
\text { : } \\
\text {. }\end{array}$ & $\begin{array}{l}\dot{0} \\
\text { : } \\
\text {. }\end{array}$ & 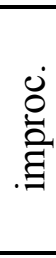 & 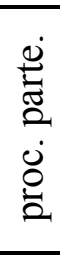 & 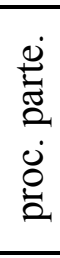 & $\begin{array}{l}\text { Oं } \\
\text { : } \\
\text { : }\end{array}$ & I & 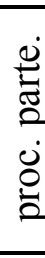 & $\begin{array}{l}\text { 这 } \\
\text { : } \\
\dot{0} \\
0 \\
0\end{array}$ \\
\hline 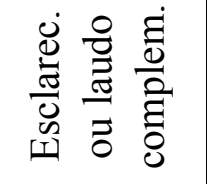 & 浇 & . & 政 & 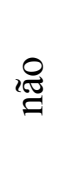 & . & 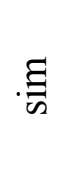 & . &.$\Xi$ & . \\
\hline 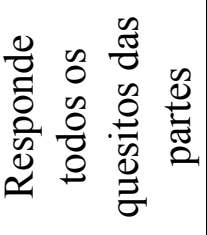 & . & 目 & . & .छ & ' & ז̊̊ & i̊ี & . & . \\
\hline 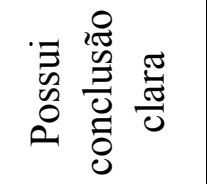 & .尹 & . & İ & . & . & $\stackrel{2}{\text { İ }}$ &.$\Xi$ & I & . \\
\hline 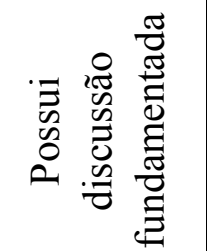 & . & 劺 & 决 & . & . & 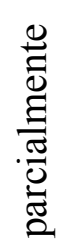 & Iี & IJ & 劺 \\
\hline $\begin{array}{l}0 \\
0 \\
0 \\
0 \\
0 \\
0 \\
0 \\
0 \\
0 \\
\dot{0} \\
0\end{array}$ & $\frac{n}{2}$ & $\begin{array}{l}\text { 1. } \\
\hat{\sigma} \\
2 \\
\sigma \\
0 \\
0 \\
\vdots \\
0\end{array}$ & $\begin{array}{l}\hat{0} \\
\hat{0}\end{array}$ & $\begin{array}{l}+ \\
1 \\
0 \\
0 \\
+ \\
\infty \\
\exists \\
\dot{0}\end{array}$ & 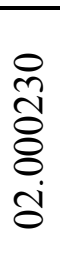 & 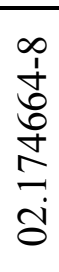 & 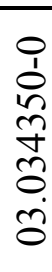 & 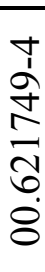 & 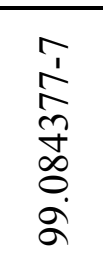 \\
\hline
\end{tabular}




\begin{tabular}{|c|c|c|c|c|c|c|c|c|c|}
\hline 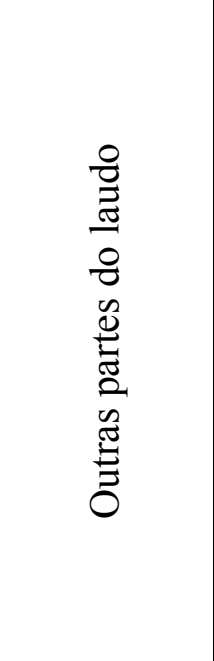 & ' & ' & 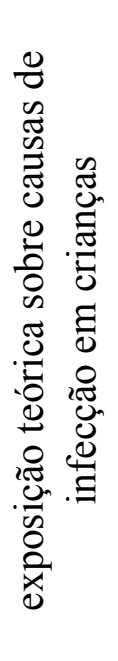 & 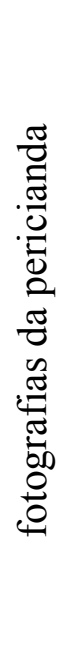 & ' & 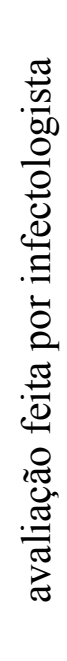 & 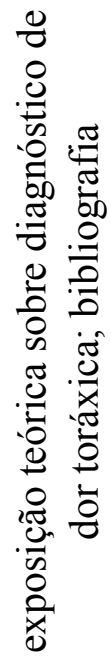 & ' & 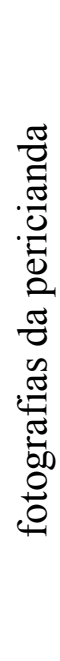 \\
\hline 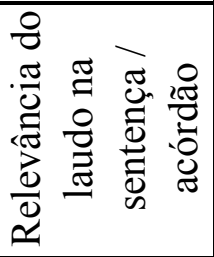 & 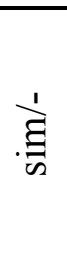 & $\stackrel{1}{m}$ & ' & 1 & 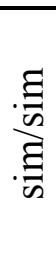 & 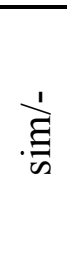 & .छ & I & $\stackrel{1}{\nexists}$ \\
\hline 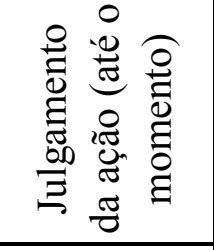 & 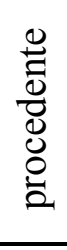 & $\begin{array}{l}\text { ठ0 } \\
\text {. } \\
.\end{array}$ & ' & ' & 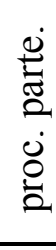 & $\begin{array}{l}\dot{0} \\
\text { : } \\
\text {. }\end{array}$ & $\begin{array}{l}\dot{0} \\
\text { : } \\
\text {. }\end{array}$ & ' & $\begin{array}{l}\dot{0} \\
\text { : } \\
0 \\
\dot{0} \\
0 \\
\dot{0}\end{array}$ \\
\hline 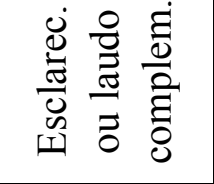 & . & 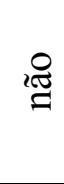 & זత్తి & I̊ & Iత્త్తి & 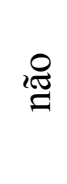 & ז̊̊ & ז̊̊ & . \\
\hline 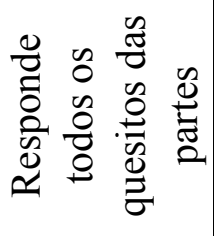 & 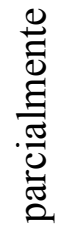 & . & . & $\Xi$ & . & $\Xi$ & $\Xi$ & ז્̊త్ & $\Xi$ \\
\hline 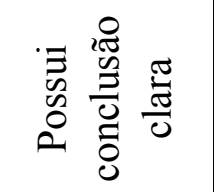 & $\Xi$ & 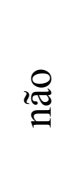 & 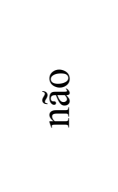 & ז̊̊ & $\Xi$ & $\Xi$ & . & . & 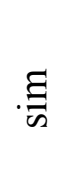 \\
\hline 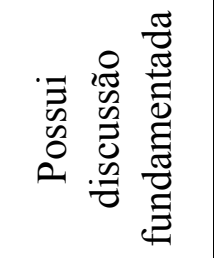 & . & 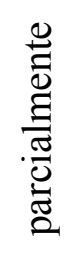 & 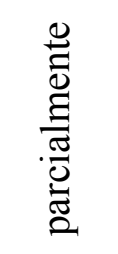 & 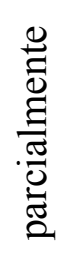 & . & . & 趽 & 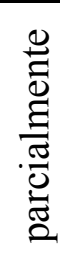 & $\Xi$ \\
\hline $\begin{array}{l}0 \\
0 \\
0 \\
0 \\
0 \\
0 \\
0 \\
0 \\
0 \\
0\end{array}$ & 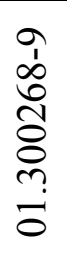 & $\begin{array}{l}\text { ô } \\
\text { ă } \\
\text { ป }\end{array}$ & $\begin{array}{l}0 \\
1 \\
\infty \\
0 \\
0 \\
0 \\
0 \\
0\end{array}$ & 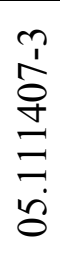 & $\begin{array}{l}n \\
1 \\
\infty \\
\infty \\
n \\
\hat{n} \\
\infty \\
2 \\
2\end{array}$ & \begin{tabular}{l}
$a$ \\
$\infty$ \\
$\infty$ \\
$m$ \\
\multirow{2}{*}{} \\
$n$ \\
8
\end{tabular} & 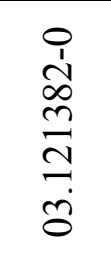 & 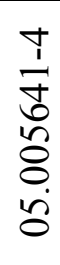 & $\begin{array}{l}n \\
1 \\
\infty \\
8 \\
0 \\
0 \\
0 \\
0\end{array}$ \\
\hline
\end{tabular}




\begin{tabular}{|c|c|c|c|c|c|c|c|c|}
\hline 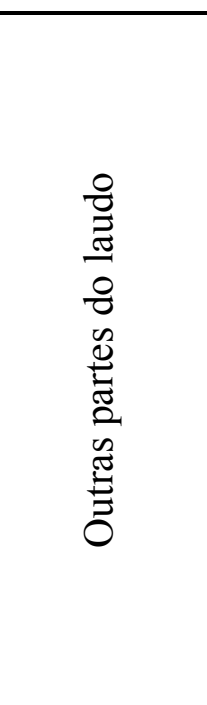 & ' & ' & ' & ' & ' & 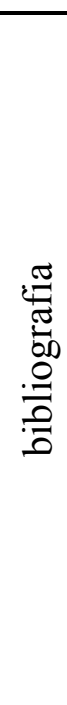 & 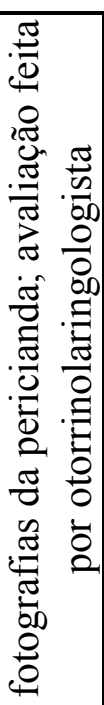 & \\
\hline 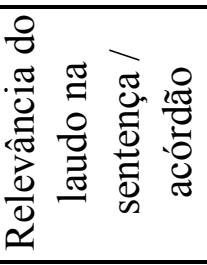 & 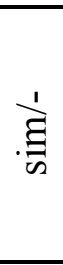 & ' & 1 & 1 & 1 & 就 & 1 & ' \\
\hline 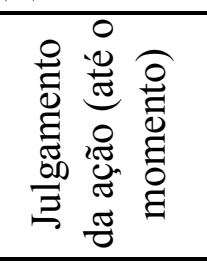 & $\begin{array}{l}\dot{0} \\
\text { : } \\
\text {. }\end{array}$ & ' & ' & ' & ' & $\begin{array}{l}\text { ¿ } \\
\text { : } \\
.\end{array}$ & ' & \\
\hline 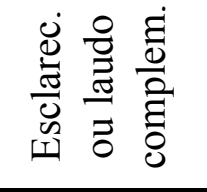 & . & i̊ & . & . & II & 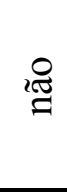 & ז̊̊ & 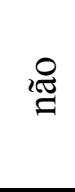 \\
\hline 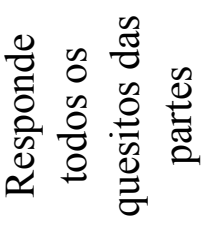 & . & $\Xi$ & . & 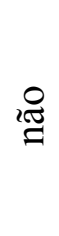 & 政 & . & 䟠 & . \\
\hline 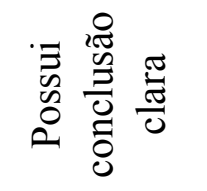 & $\Xi$ & 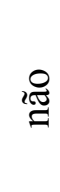 & 痣 & શ્લ્త్ & 疎 & . & 跑 & 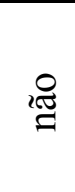 \\
\hline 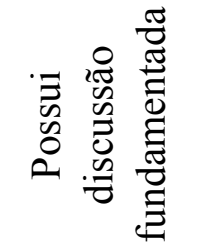 & $\Xi$ & 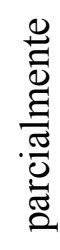 & 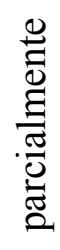 & 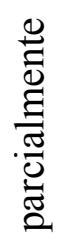 & 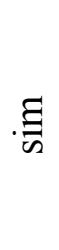 & . & . & 急 \\
\hline $\begin{array}{l}0 \\
0 \\
0 \\
0 \\
0 \\
0 \\
0 \\
0 \\
0 \\
\dot{Z}\end{array}$ & $\frac{\mathfrak{\partial}}{\frac{\partial}{\sigma}}$ & $\frac{+}{\infty}$ & 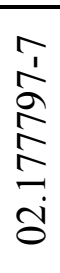 & $\begin{array}{l} \pm \\
\text { I } \\
=\end{array}$ & $\begin{array}{l}n \\
n \\
m \\
n \\
n \\
0 \\
0 \\
\ddot{0}\end{array}$ & 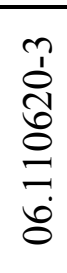 & $\begin{array}{l}\infty \\
\dot{1} \\
\dot{0} \\
\mathbb{1} \\
0 \\
0 \\
0 \\
\dot{0}\end{array}$ & 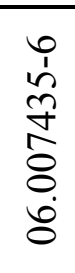 \\
\hline
\end{tabular}




\begin{tabular}{|c|c|c|c|c|c|c|c|}
\hline 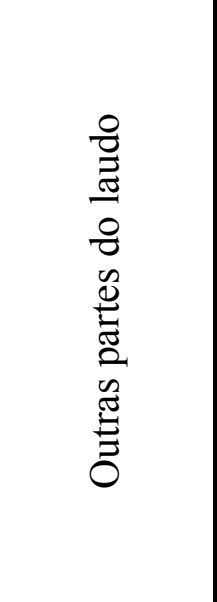 & 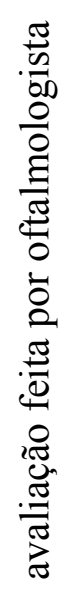 & 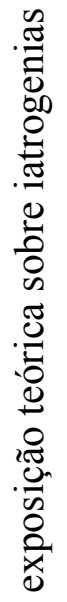 & 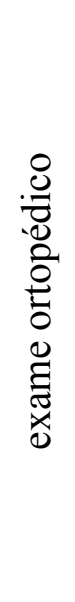 & ' & 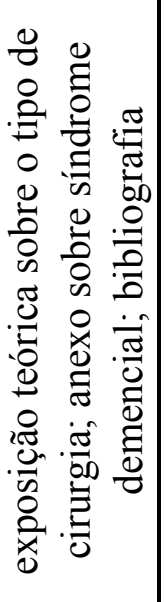 & ' & 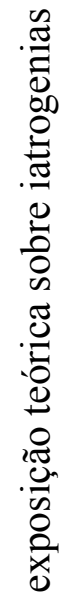 \\
\hline 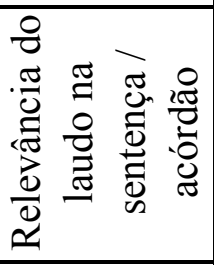 & ' & ' & ' & ' & ' & ' & ' \\
\hline 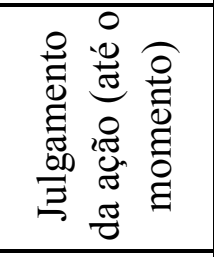 & ' & ' & ' & ' & ' & ' & ' \\
\hline 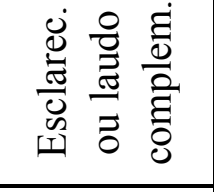 & 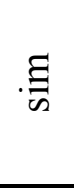 & .g & 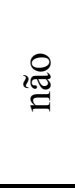 & . & . & . & $\cdot g$ \\
\hline 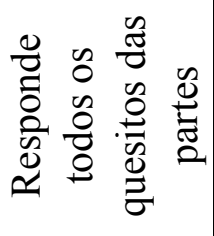 & $\Xi$ & II & 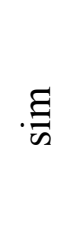 & 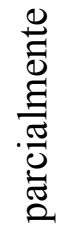 & .g & .g & $\stackrel{\text { İ }}{=}$ \\
\hline 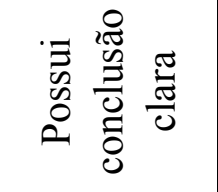 & .g & ĩ్తి & .g & Iత్త & . & . & 梽 \\
\hline 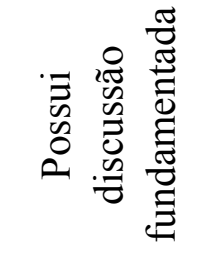 & $\Xi \Xi$ & II & 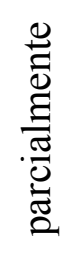 & 2త్తి & .g &.$\Xi$ & 掭 \\
\hline $\begin{array}{l}0 \\
0 \\
0 \\
0 \\
0 \\
0 \\
0 \\
o \\
0 \\
0 \\
0\end{array}$ & 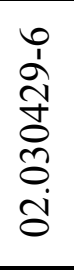 & $\begin{array}{l}0 \\
\stackrel{1}{1} \\
0 \\
2 \\
0 \\
0 \\
\ddot{0}\end{array}$ & 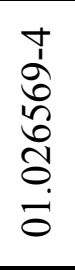 & $\begin{array}{l}\infty \\
1 \\
\infty \\
\infty \\
\infty \\
= \\
\cdots \\
\infty\end{array}$ & 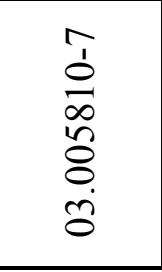 & $\begin{array}{l}\frac{2}{2} \\
\frac{2}{n}\end{array}$ & $\frac{\sqrt{2}}{\frac{1}{2}}$ \\
\hline
\end{tabular}




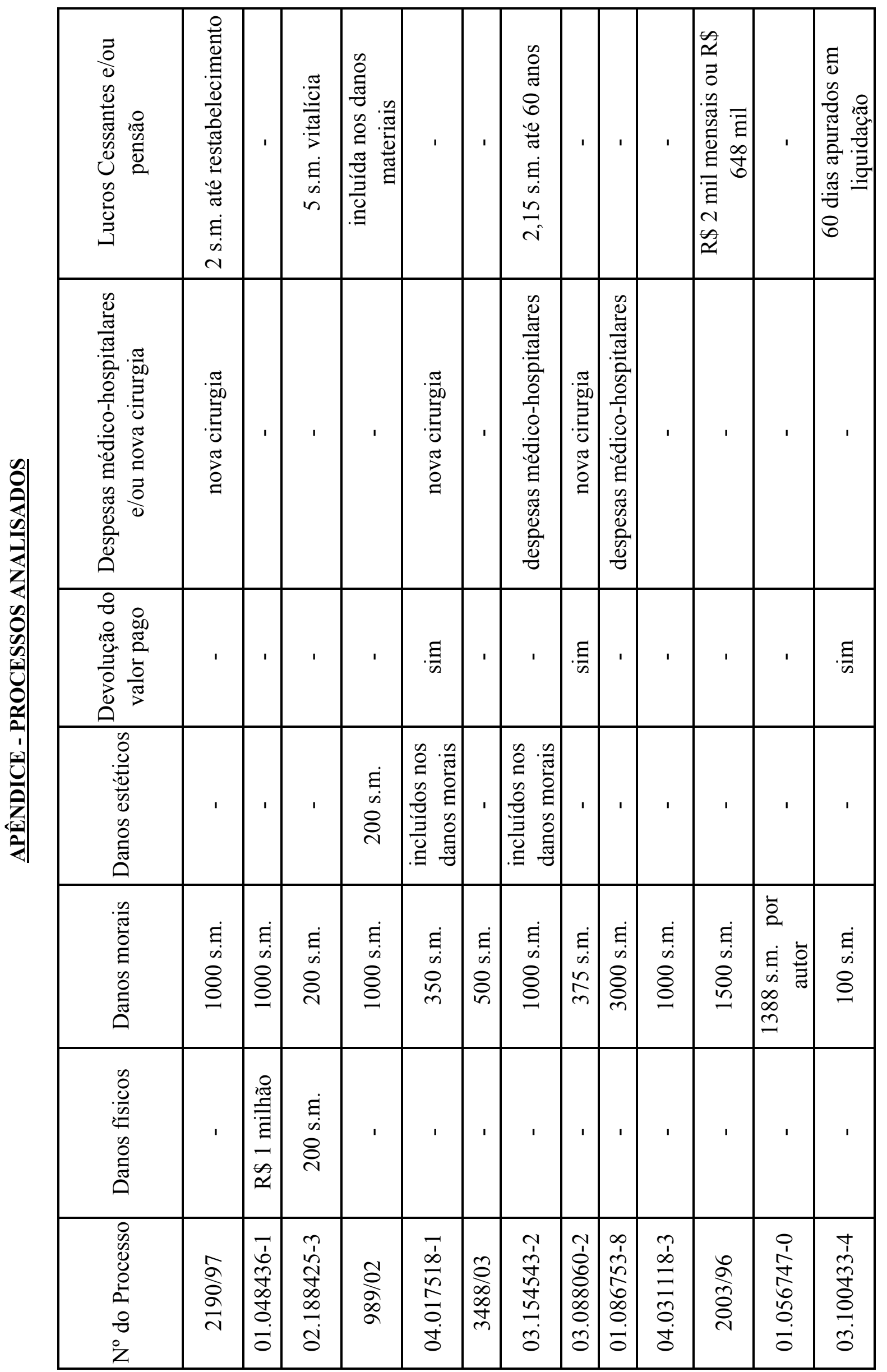




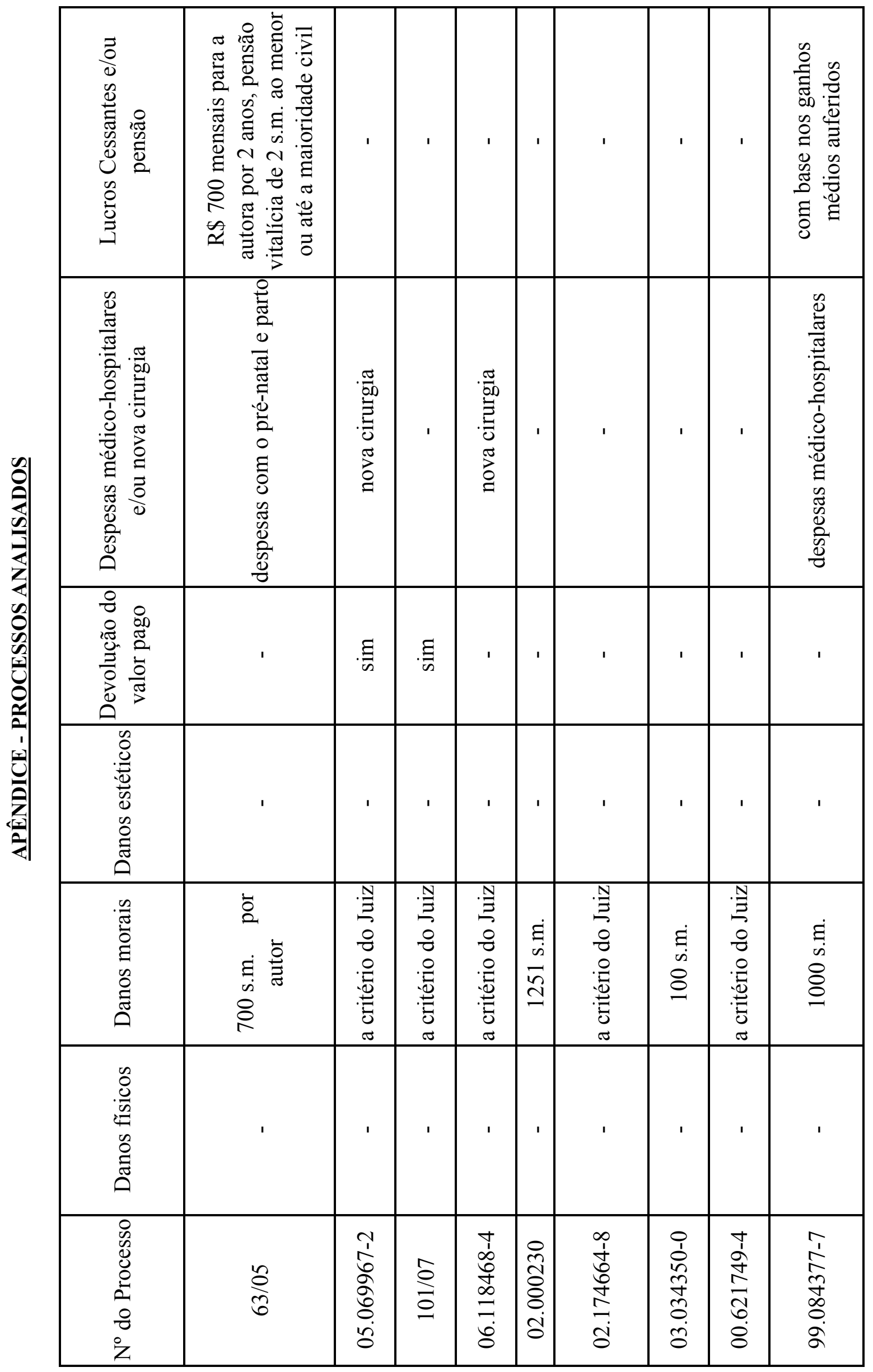




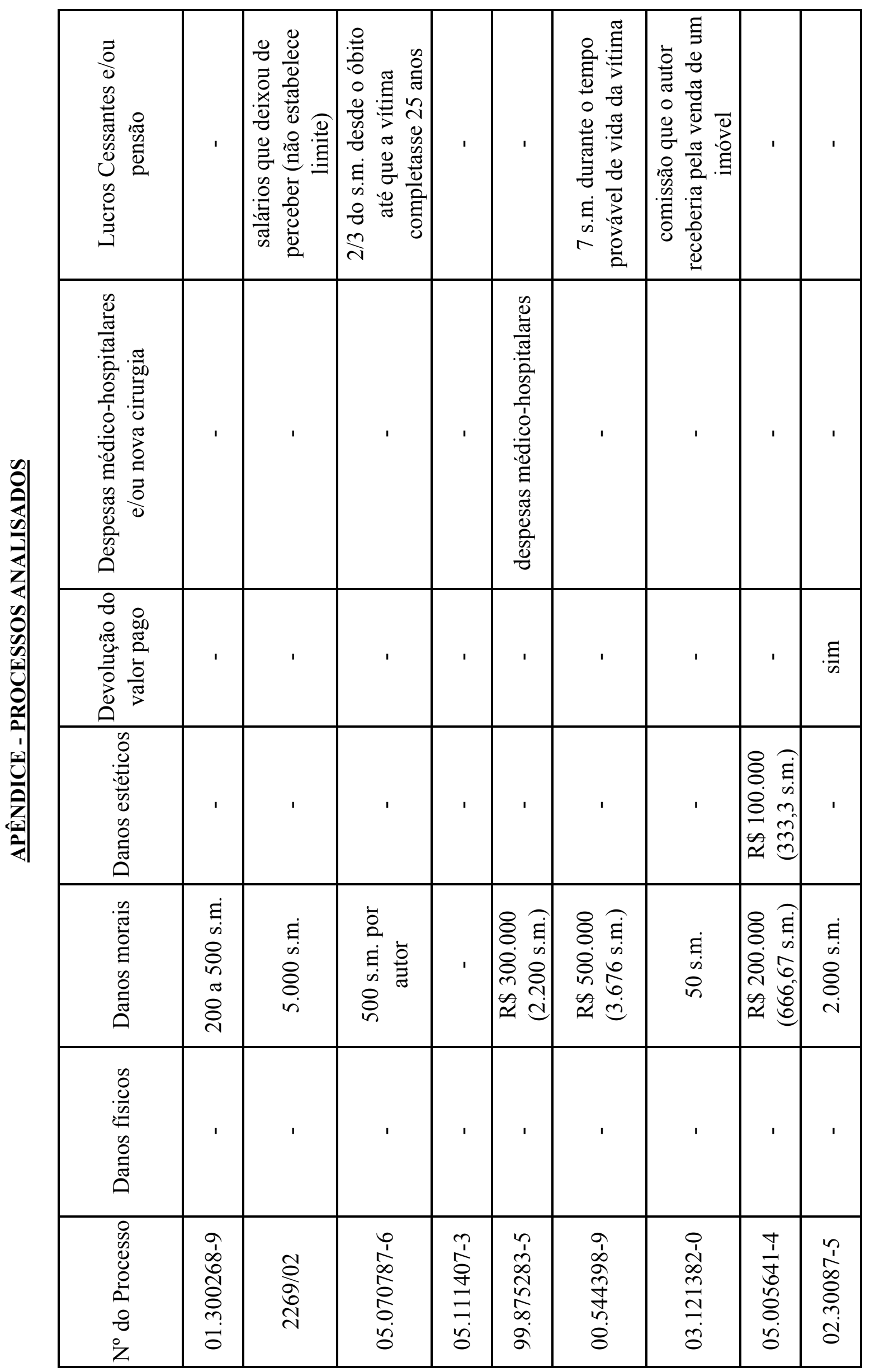




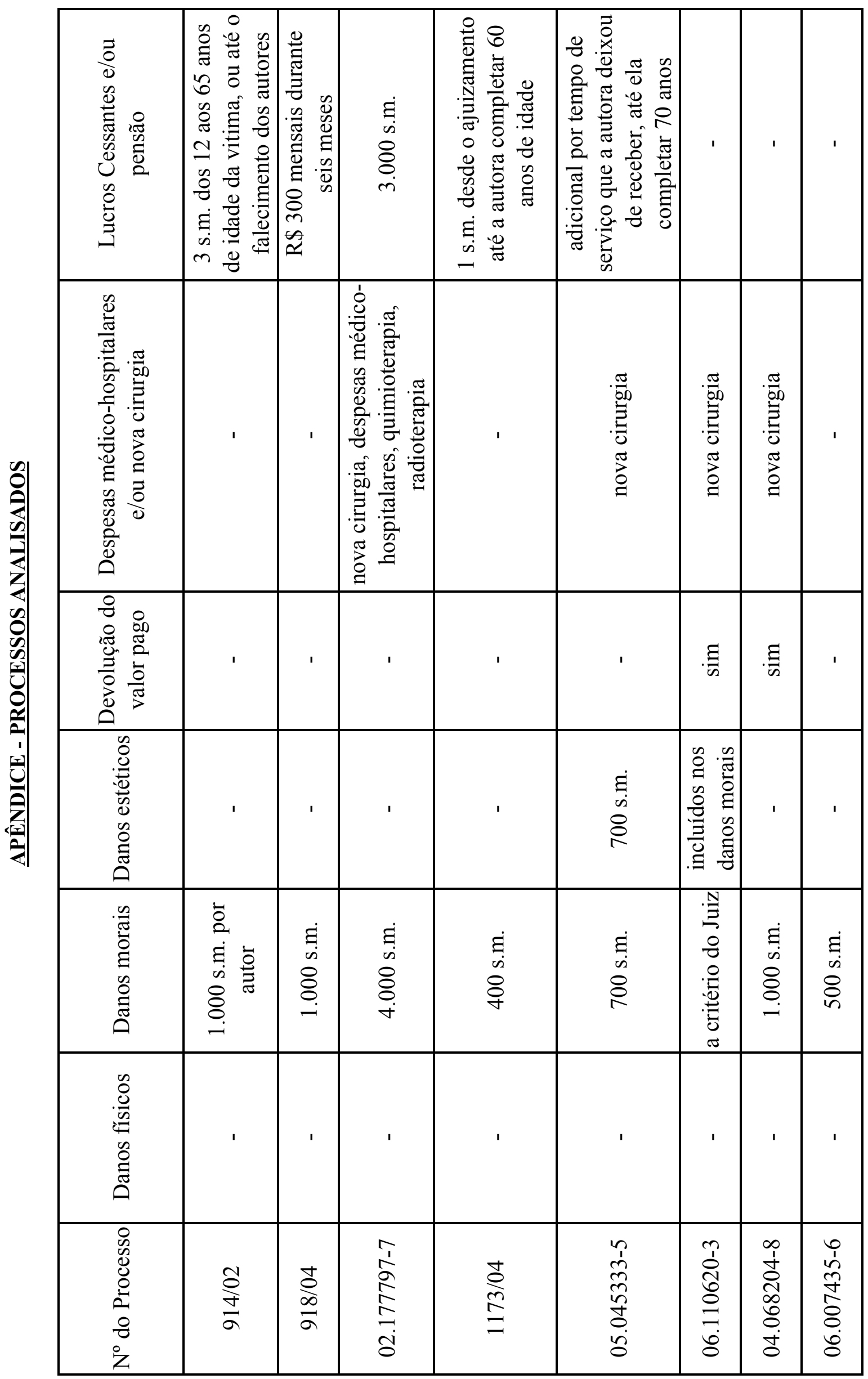




\begin{tabular}{|c|c|c|c|c|c|c|c|}
\hline 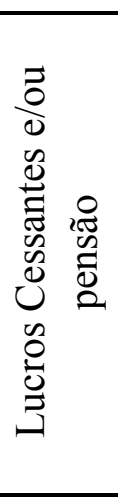 & 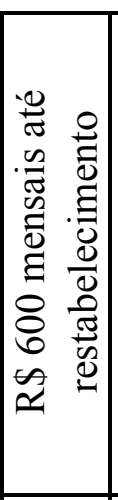 & ' & 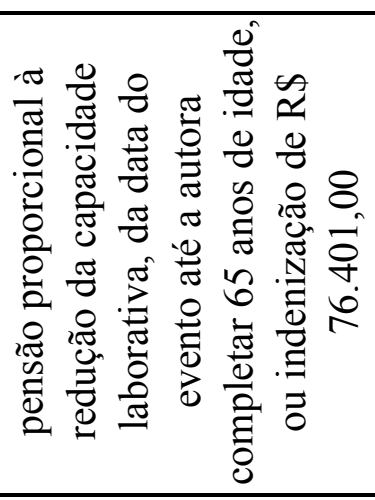 & ' & ' & ' & ' \\
\hline 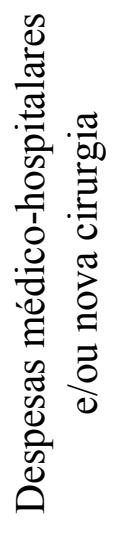 & ' & 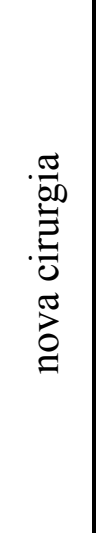 & 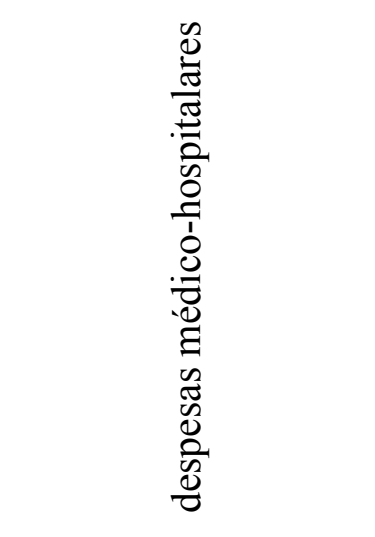 & 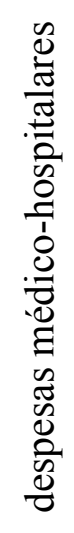 & ' & ' & ' \\
\hline 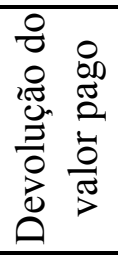 & ' & ' & ' & ' & ' & ' & ' \\
\hline 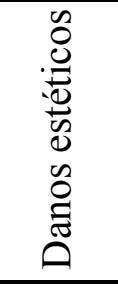 & ' & 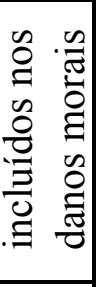 & ' & ' & ' & ' & ' \\
\hline 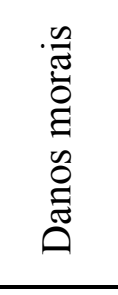 & 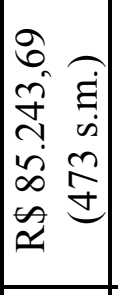 & 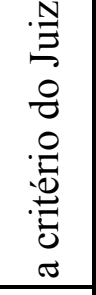 & $\begin{array}{l}\dot{g} \\
\dot{\infty} \\
8 \\
\dot{8}\end{array}$ & $\begin{array}{l}\dot{\Xi} \\
\dot{n} \\
8 \\
\stackrel{8}{0} \\
\dot{\nu}\end{array}$ & $\begin{array}{l}\dot{\Xi} \\
\dot{\infty} \\
8 \\
8 \\
\text { ம }\end{array}$ & ' & $\begin{array}{l}\dot{1} \\
\dot{\infty} \\
8 \\
8 \\
0\end{array}$ \\
\hline 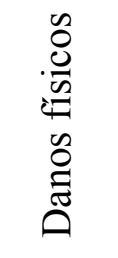 & ' & ' & ' & ' & ' & ' & ' \\
\hline $\begin{array}{l}0 \\
0 \\
0 \\
0 \\
0 \\
0 \\
0 \\
0 \\
0 \\
z\end{array}$ & 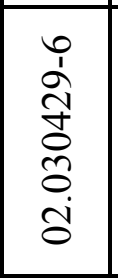 & 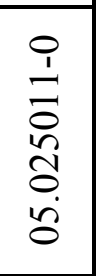 & 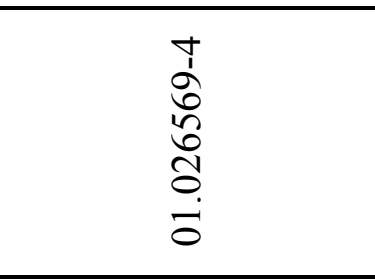 & $\begin{array}{l}\infty \\
1 \\
\infty \\
\infty \\
\infty \\
ٍ \\
\cdots \\
\infty\end{array}$ & $\begin{array}{l}1 \\
0 \\
\infty \\
0 \\
\delta \\
0 \\
0\end{array}$ & $\begin{array}{l}\text { à } \\
\text { à } \\
\text { ñ }\end{array}$ & $\frac{\curvearrowright}{\precsim}$ \\
\hline
\end{tabular}




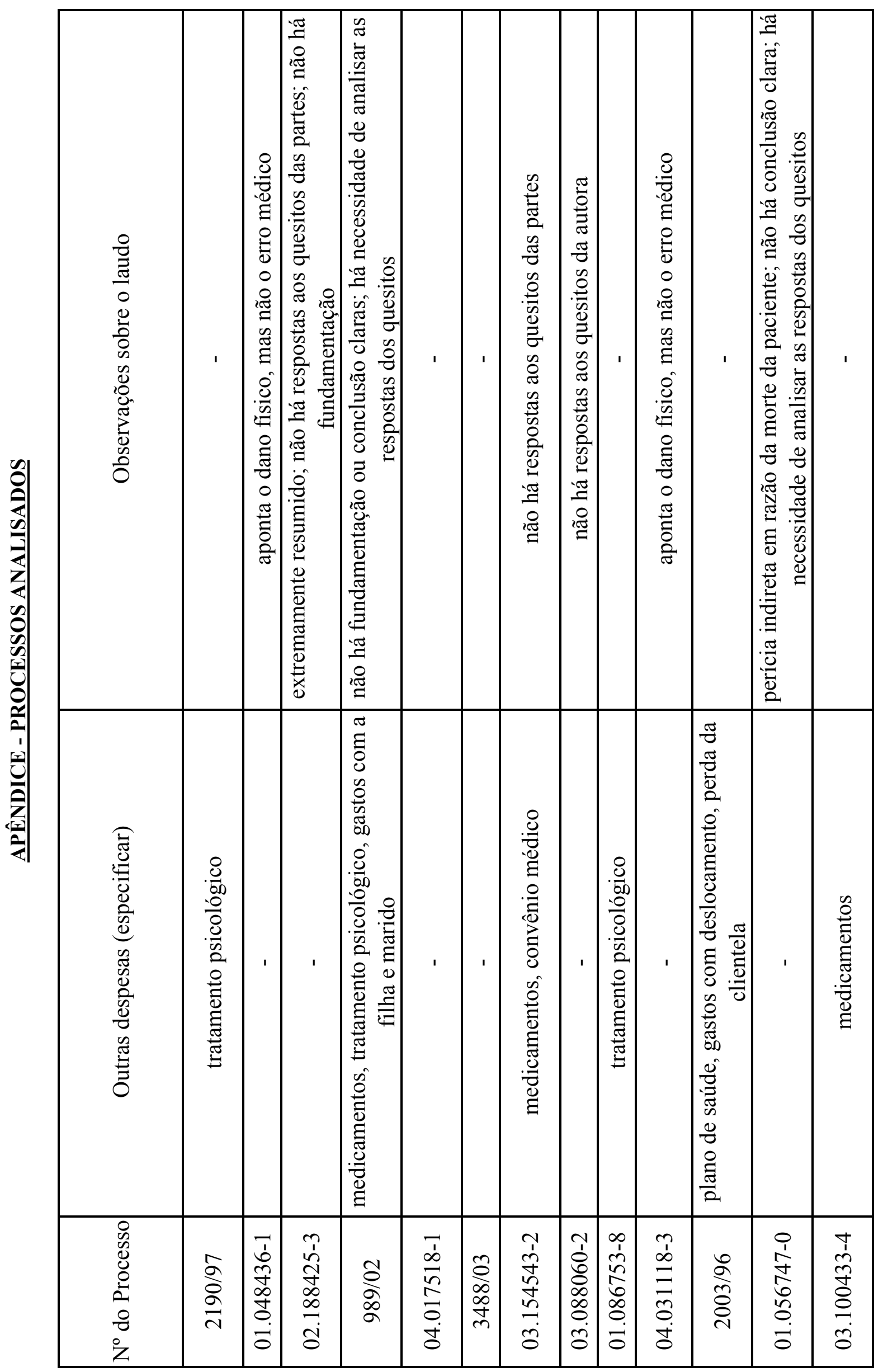




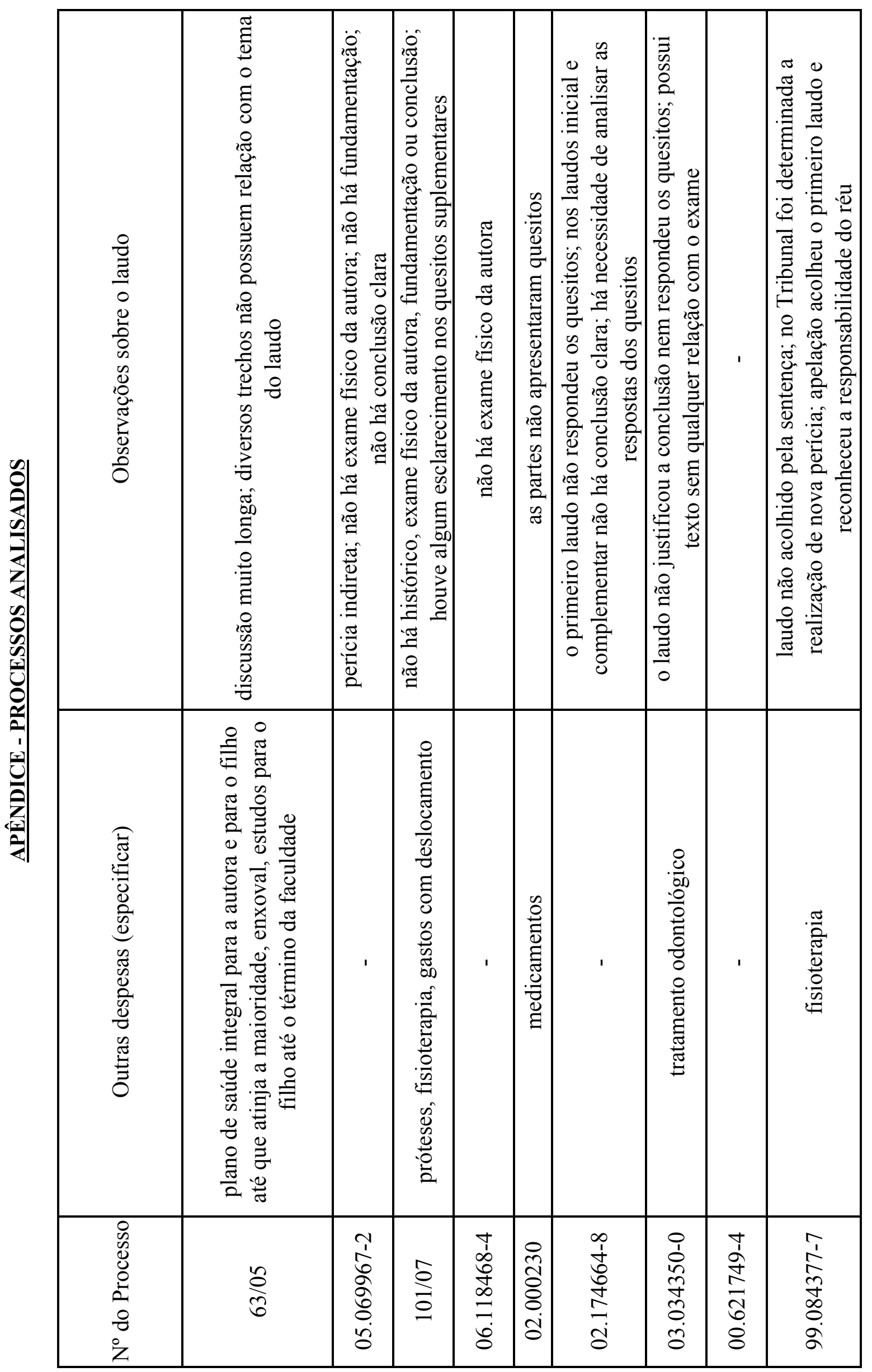




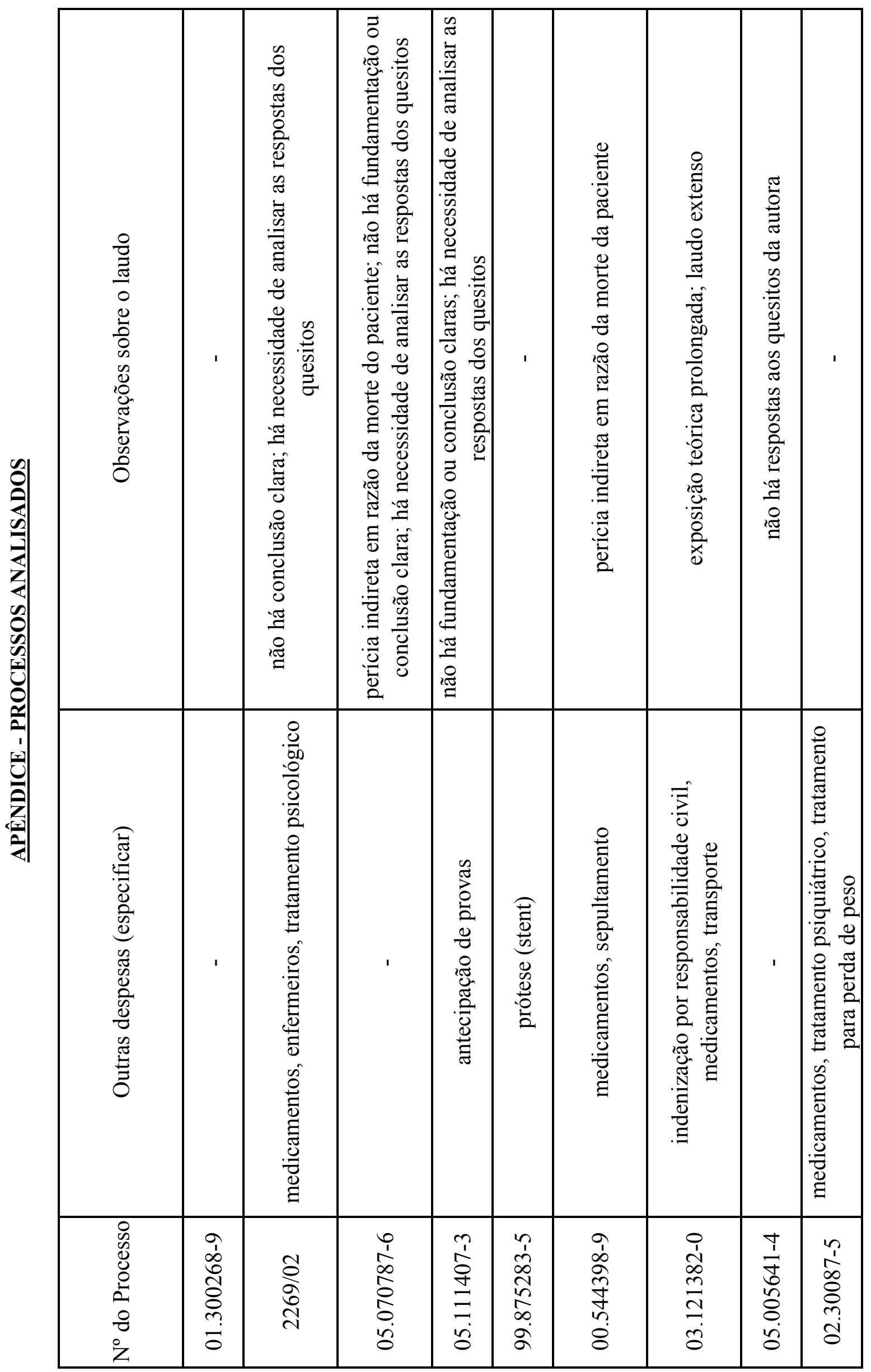




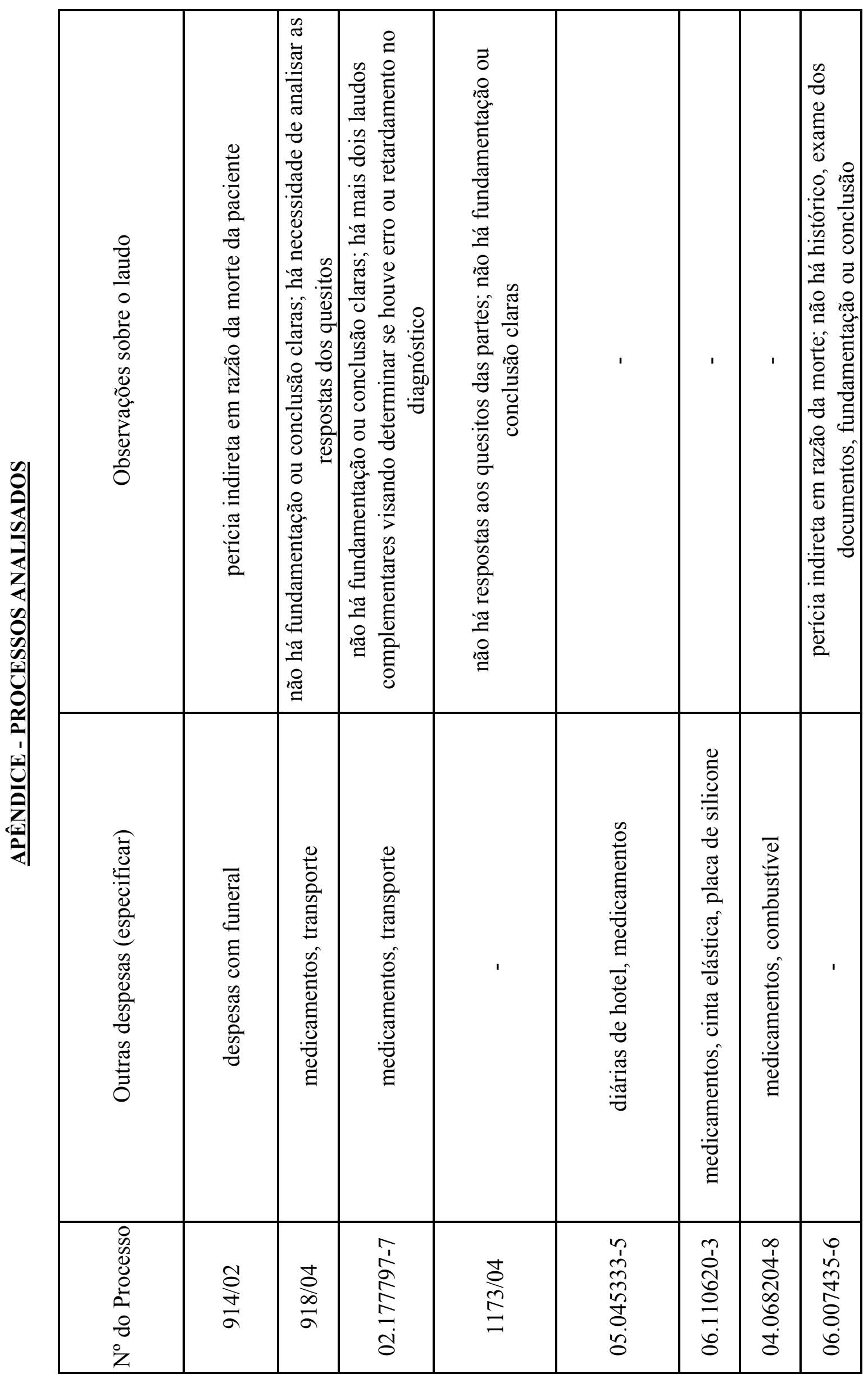




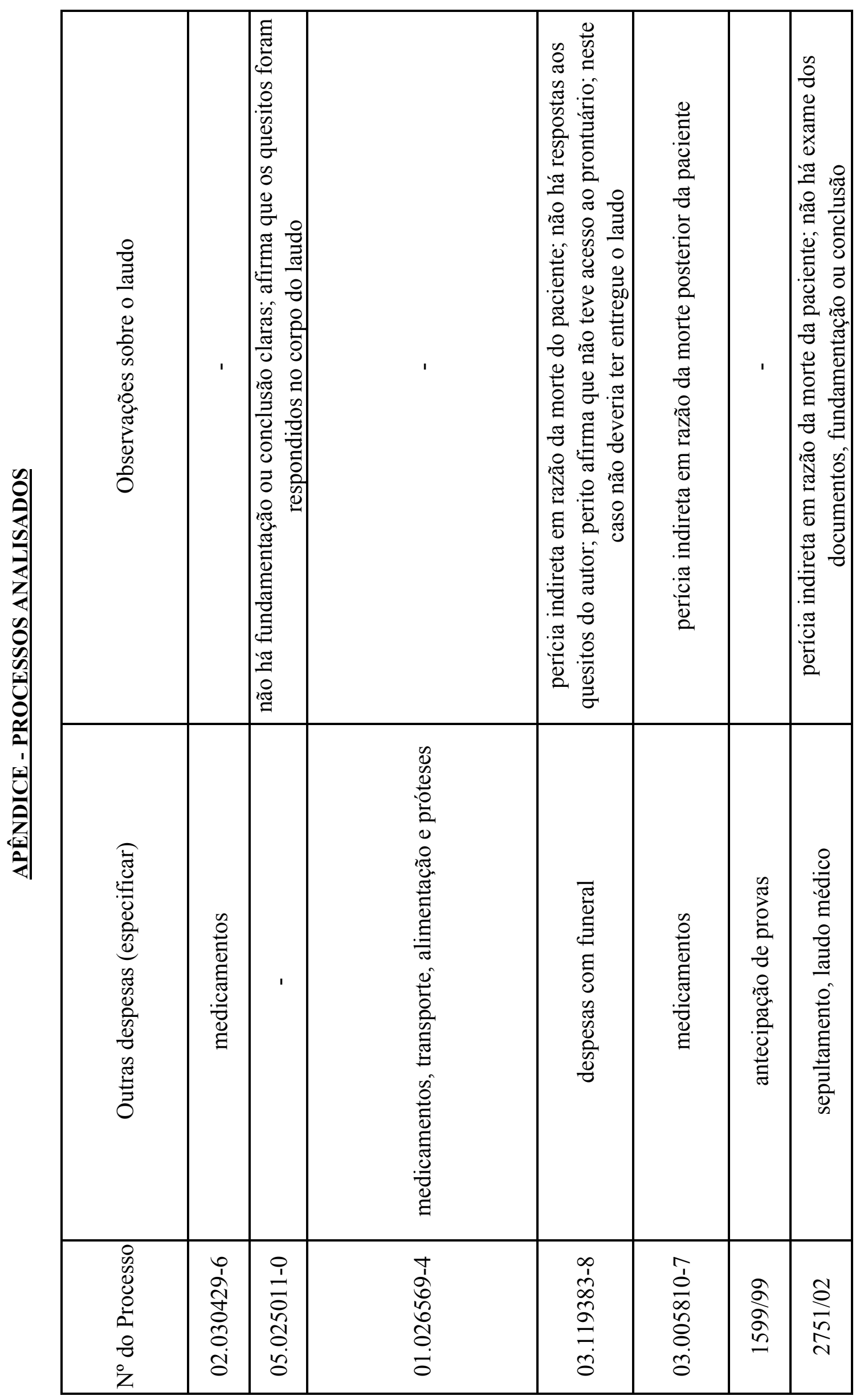

